University of Louisville

ThinkIR: The University of Louisville's Institutional Repository

Electronic Theses and Dissertations

1940

\title{
A study of the cohesive and adhesive properties of asphalt.
}

Harold Rose 1918-1997

University of Louisville

Follow this and additional works at: https://ir.library.louisville.edu/etd

Part of the Chemical Engineering Commons

\section{Recommended Citation}

Rose, Harold 1918-1997, "A study of the cohesive and adhesive properties of asphalt." (1940). Electronic Theses and Dissertations. Paper 1882.

https://doi.org/10.18297/etd/1882

This Master's Thesis is brought to you for free and open access by ThinkIR: The University of Louisville's Institutional Repository. It has been accepted for inclusion in Electronic Theses and Dissertations by an authorized administrator of ThinkIR: The University of Louisville's Institutional Repository. This title appears here courtesy of the author, who has retained all other copyrights. For more information, please contact thinkir@louisville.edu. 


$$
\text { vinmetry or noustrus }
$$

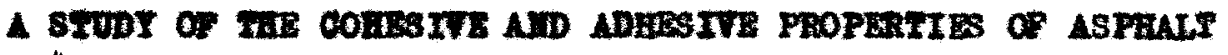

\author{
4 moele \\ Subaltted to the Fonity \\ of the Craduate sohool \\ of the Antreretty of Lonisurlue \\ In Fartial Fanflineat \\ of the Degnirwent \\ for the Degree of
}

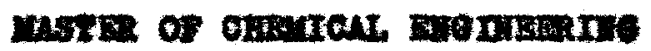

Bepartmont of Chenteal Buglneering

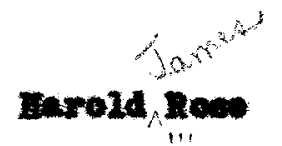

1040 


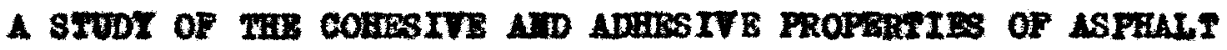

HAROCD ROSE

Approved by bevalning cownttee:

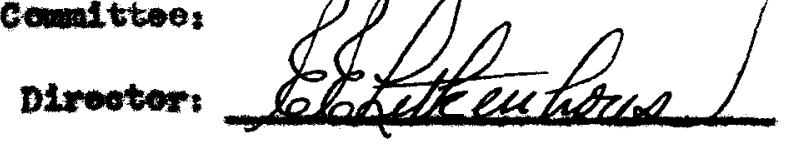
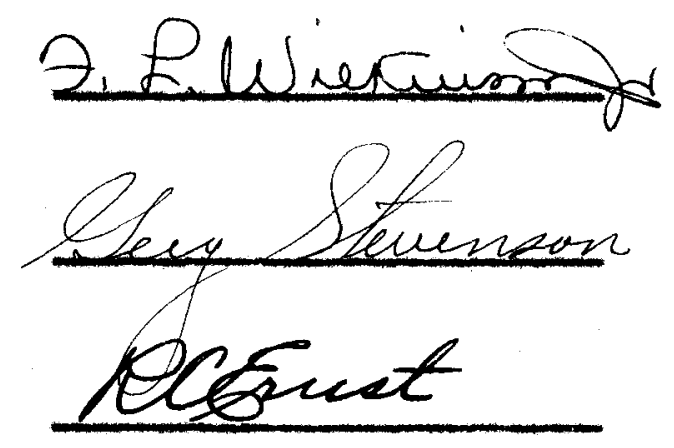

Dato: Iny 8: 2940

13276 
rume of sourans

PABS

Ilet of mabies ....................11

List of Mgares. ................... 111 soknouledgmont ......................... Abetraot .......................... Intredeotion ......................... 1 Breterien $\ldots \ldots \ldots \ldots$

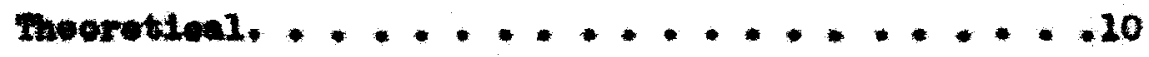

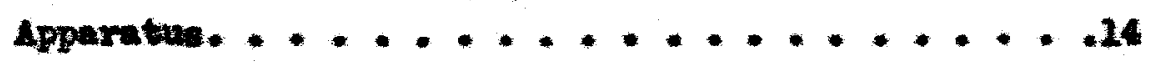

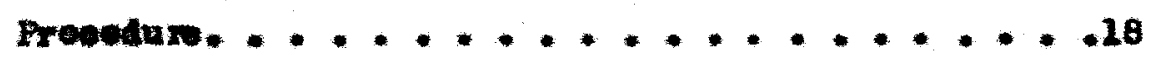

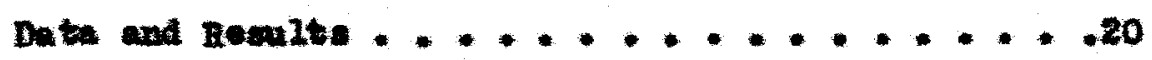
Phyaleal Proportice. .................48 Divenuaton of Rosalta. .................69

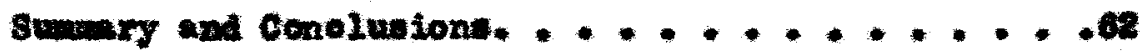
Appondix ........................64 Semple culoulation . ...............65 Lttorature Citud. ................66

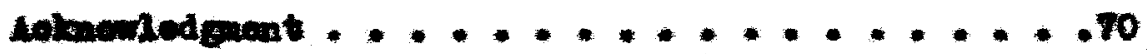
$\boldsymbol{r}$ t $\ldots \ldots \ldots \ldots \ldots \ldots \ldots$ 
LIST of runss

TANG

PLOE

I searee of Grude and Proporties of samples. ........ 2

II Ceordinates for the Bate of Rlow Curve of Lead Shot. * . 22

III Reanits of thesive and Cohestro reots of

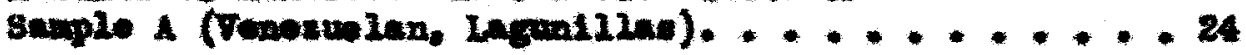

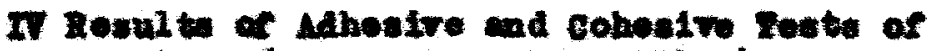
Serple (Tenomelan, Lagmilias)............ 26

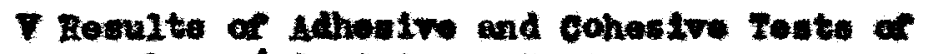

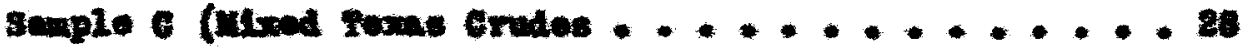

VI Renulte of Adhodiro and Coboutre seate of Benplo D (Betth Amoriloan Grates) ............. 30

VII Reaulte Adhestre and Rohostre Tore or

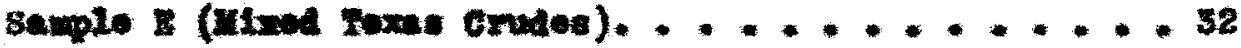

VII Rovul to of Mdhoaive and cobesive reate of semple $($ Mesna Grudes). ................. 3

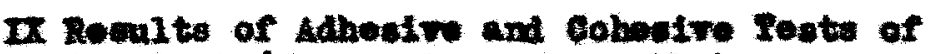

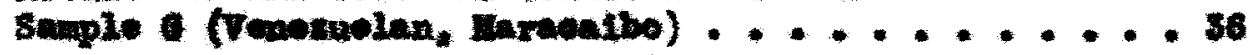

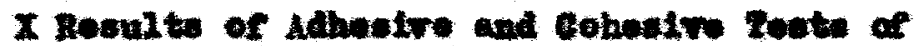

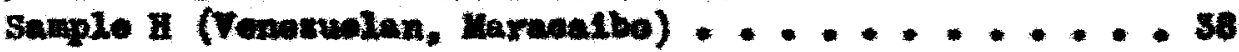

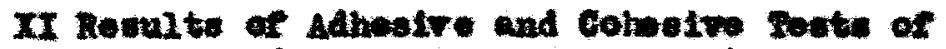
semple I (Tenamalan, Maraoafbo) $\ldots \ldots \ldots$

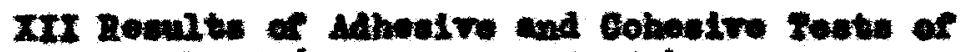

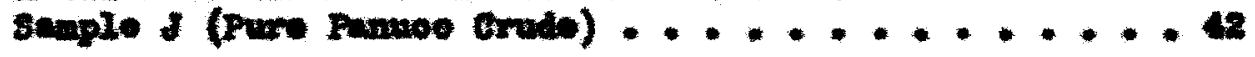

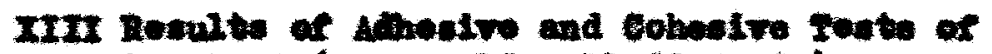
8anple I (Pore sulnar Bure arado) .............4

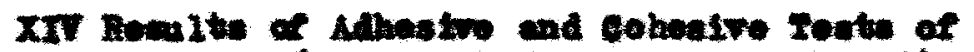

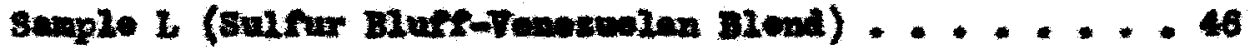

XI Sortaing Polnti of Apphalt samploa* .......... 51 IVI Fonotration of Aophelt Sanples at Varying Temperatrurea - 58 


\section{LI87 or rroutes}

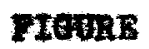

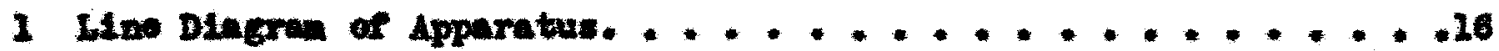

In Diegrem of steel plates of reet Fanel. ..............17

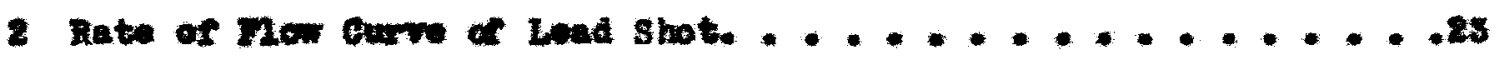

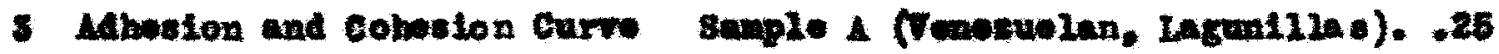

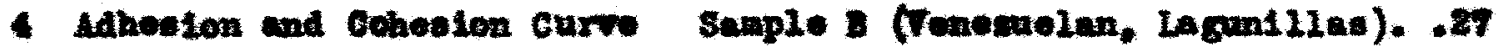

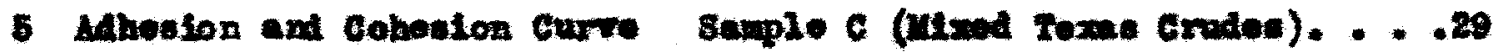

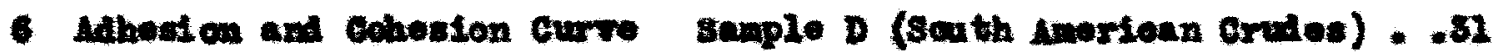

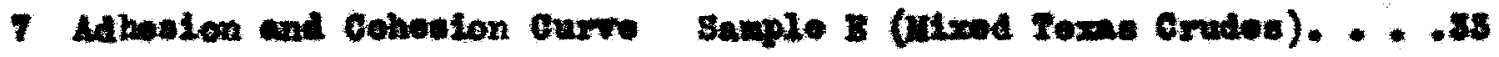

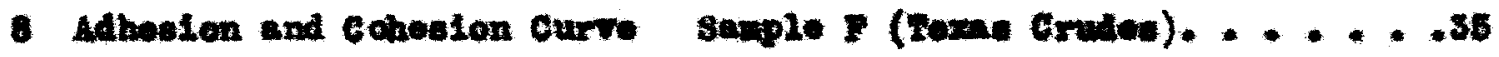

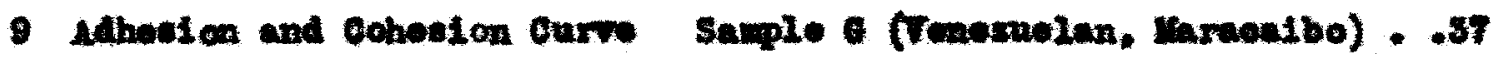

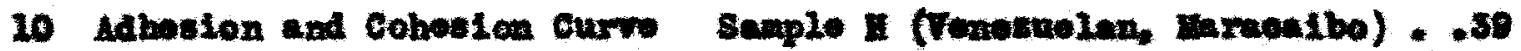

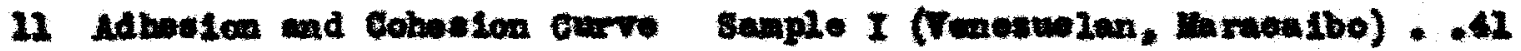

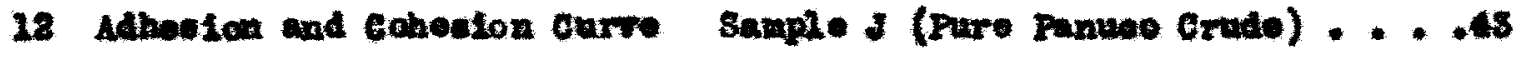

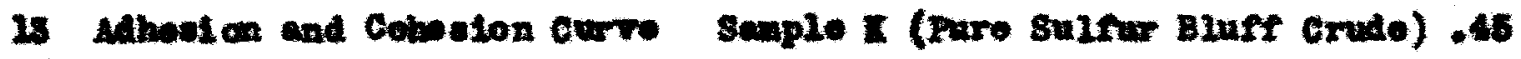

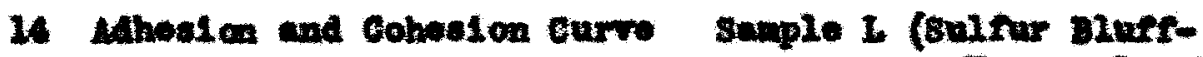

Tenounaten Blond). ...47

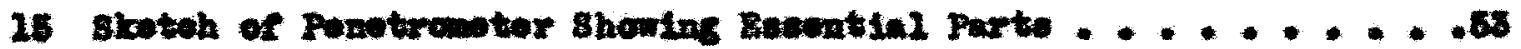

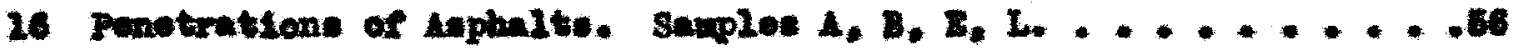

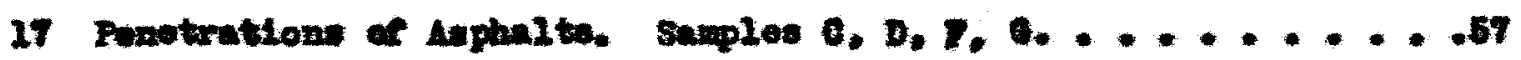

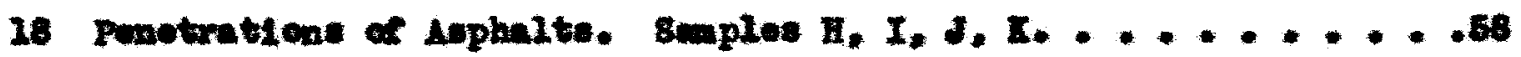

19 Photograph or Apparatut. .........................68

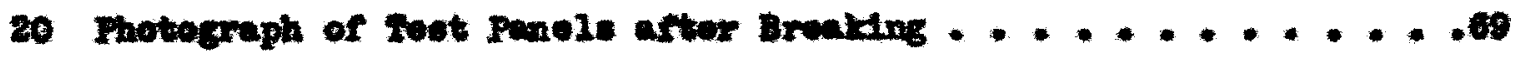


ACKTONLEDGEMENT

The exther wabe to clmoninds the

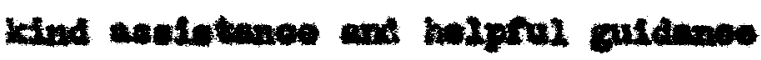

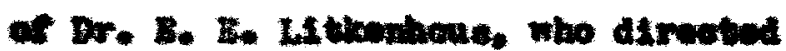
bits ronowrot. 


\begin{abstract}
Anstang

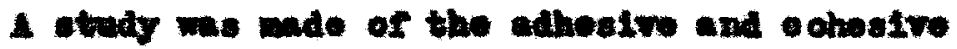
otrongthe of various blom sophults and an attempt me wade to eorrelate those ralues with the ocmenily eoepta phyoleal bets, cortemins polnt. penotration, and anotility.

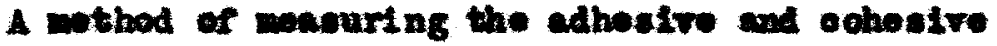

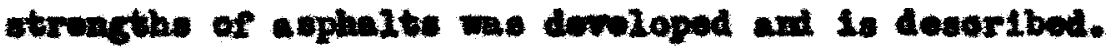
curve of ahoulre and oohestre atrongth agnind temperature are plottwd. Those ourres give an indieablen of the adeptability of the eaphalt for ementing purposes. 4 wothed of the type oould be uend in writ

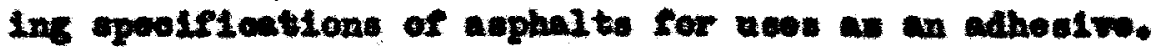


IHzopencrox 
A measure of adhosion or oobesion, together with othor ecoppted

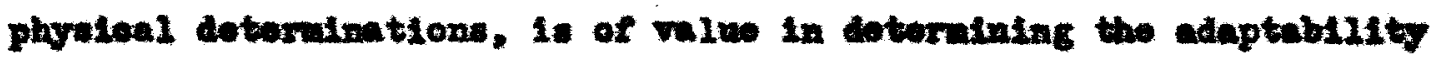

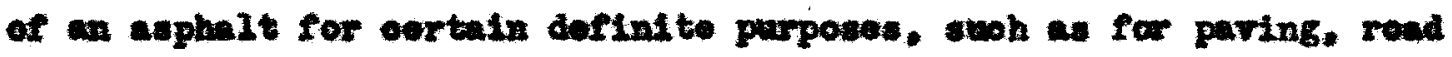
building. the manfacture of oompoands for mtoxproofing and bullt-up

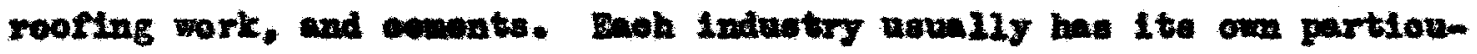
Iar bot for these two proporties deponding upon the bype of work in wiok the apphalt is ued. It would be adrentageous to oarrolate com hesten and adhosion with other woopted omptrion toats on aophalto.

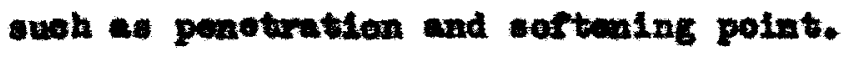

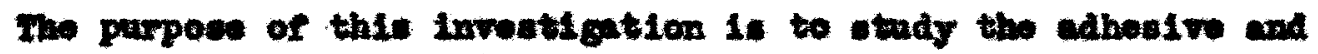
ooheelve strengthe of varlous alr blown petreleum aophalts.

It we proposed to study these two proporties by (1) obtating

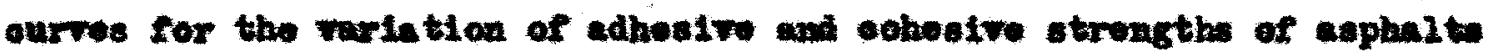
manfuctured from difforont orudes dth tomporature and (2) revioning the reolut obtainod frem these ourves wh rwapeat to sone of the existing expirieal proporties, sueh as ponotration, seftening point. and dustisty.

A therowgh eareh of the iltoreture revealed that vory 11 thlo wort bie bea done on this abjeot. 
Erstonteat 


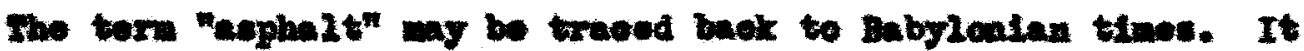

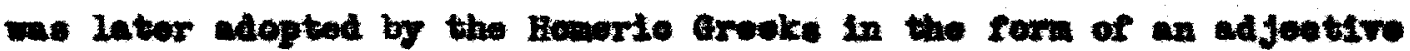

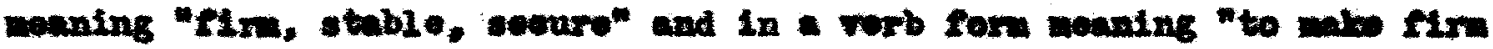

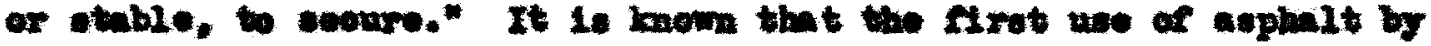

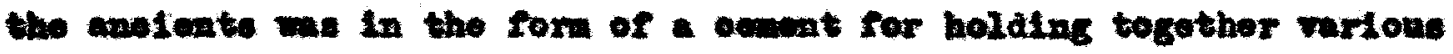

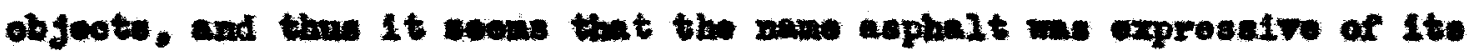
nee (1).

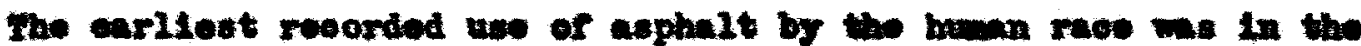

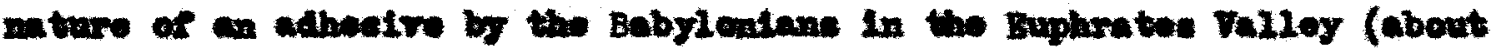

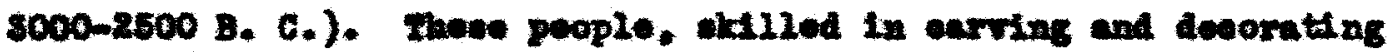

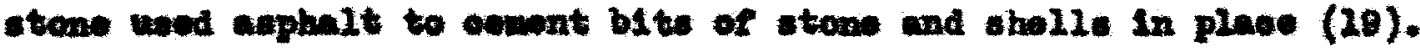

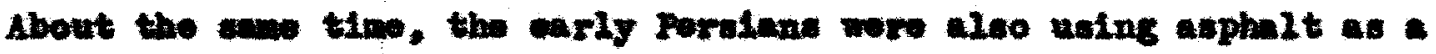
natorial to owmat gro in alabestor rigures (7).

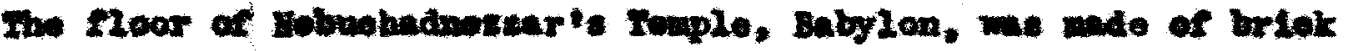

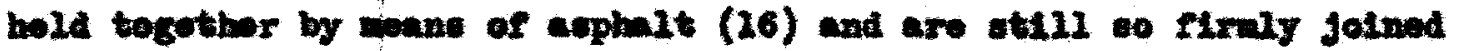

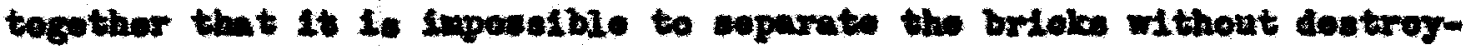
ing thom.

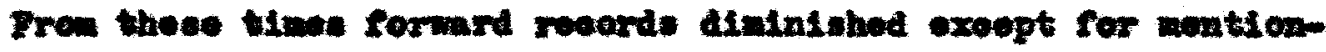

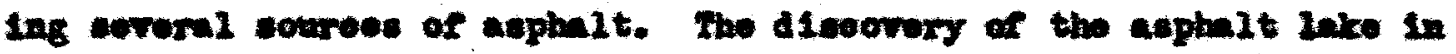
Irinidad in 2505 by sir Waltor Relelgh (16) oturtod the nodorn hictory

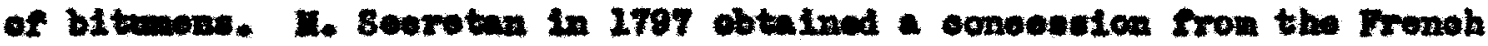

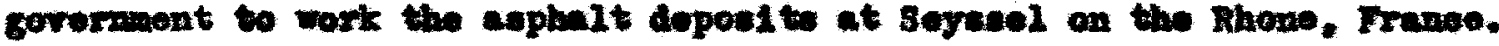

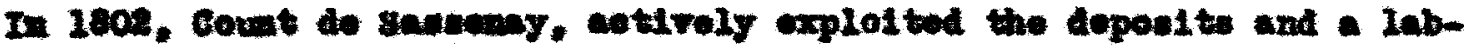
oratory was bailt te imveots gate the noes of this acphalt. 


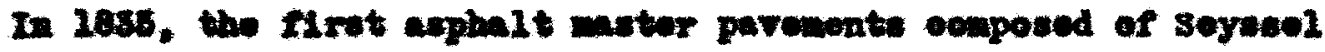
anpialt wore Ield in Pert Rogel, Rarte (10). In 1856, London followed

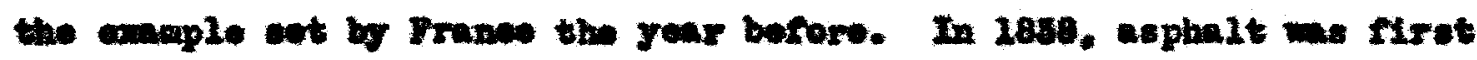

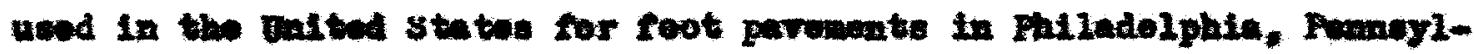
vanis. seyogel eophedt we now sor this purpose.

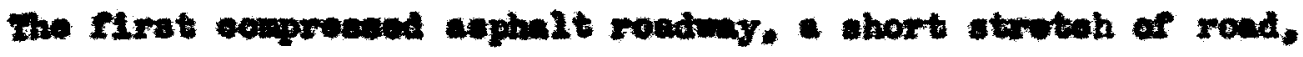

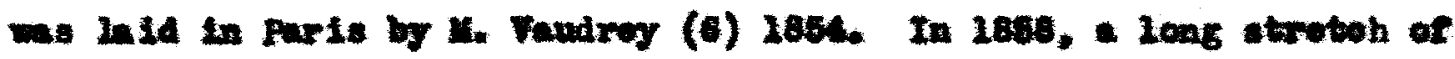
asphalt roadray we construeted on the pulais Regal and on the Ine st.

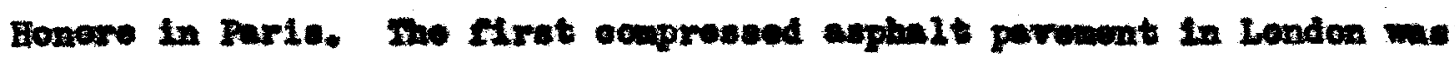

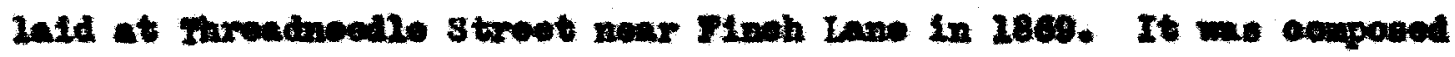

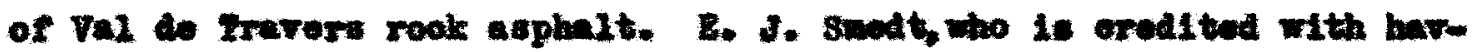

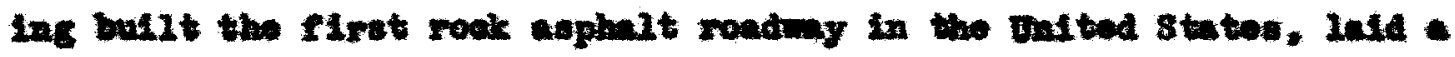

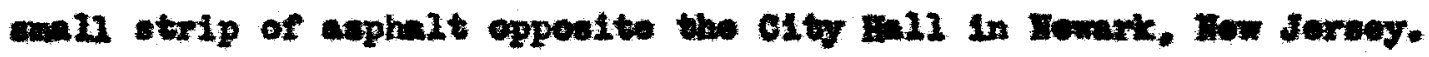
This roak appladt wo wald to bo too suppery, and in 1876 the firut

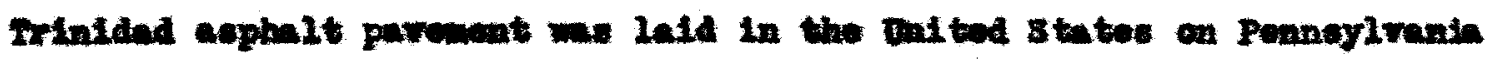

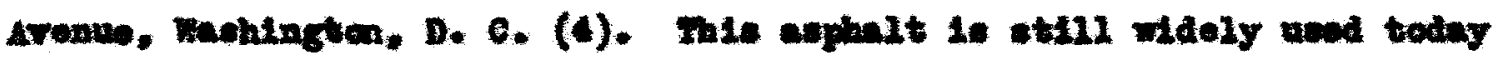
In read aconitrontion.

Athough apphalt ba boon uned for corowal thousand yours in

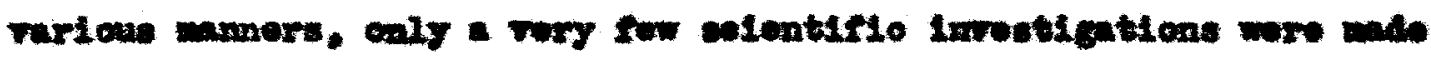
on this mteriel unt11 the lact part of the 10th eentrary. Irom 1000

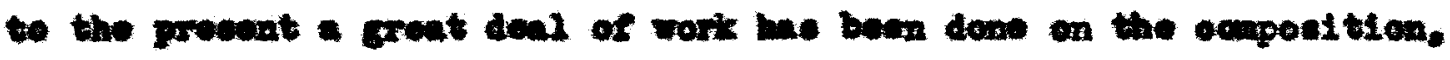

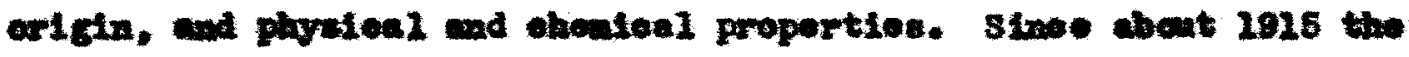

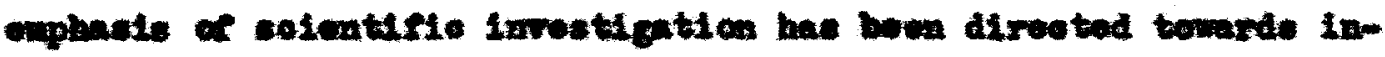

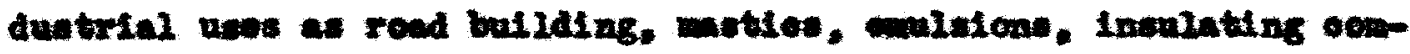
pounde, and probostive eoting. 


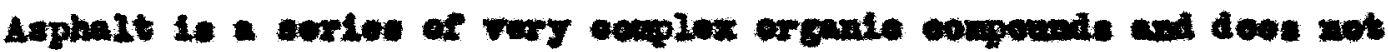

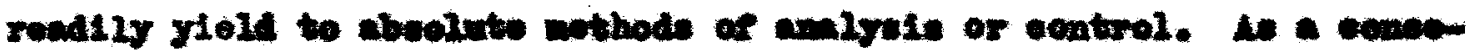

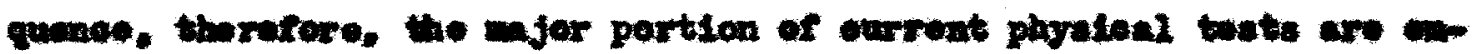

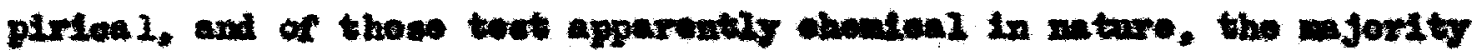
ar. Interprobed maplrienliy.

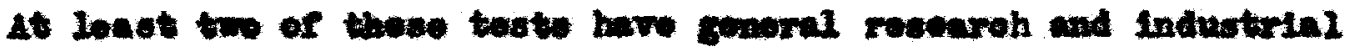

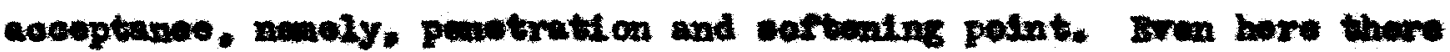

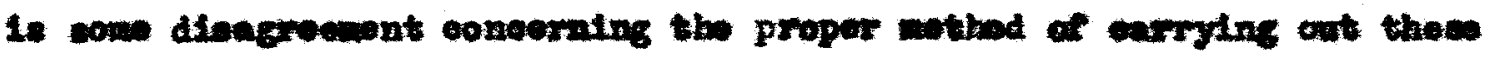
realte. Dut minly through the Impotal of the Anoriean sookety of

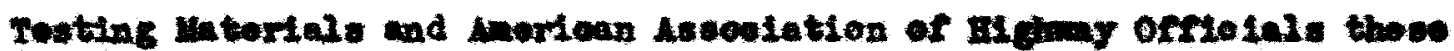

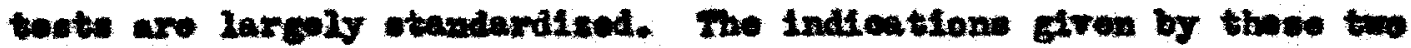

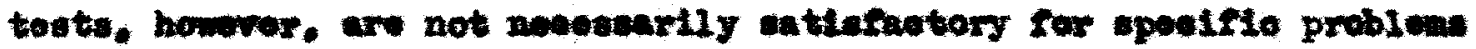
but serme malniy as athod of eleselfieation.

Spieluan (21) any

Tt It of intwret and inportanoe, both for colenthice and pratileal parperes, to deternine whother and how tar ane proporty raries rogaierly ath anothar or is outireif indopondent of 1t. This mibjeat roquires wor attention to be pald to it then has alrudy been cirwa.

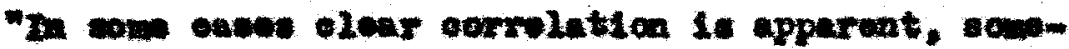

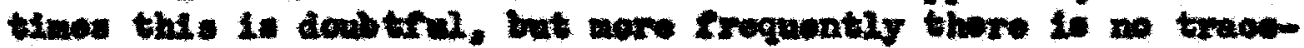

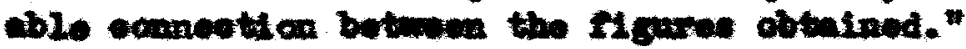

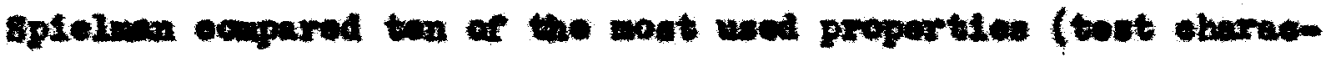

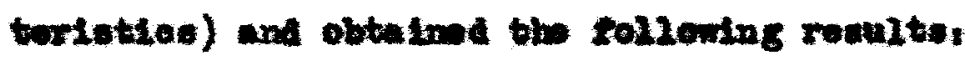

Coriens correlation Dabbrul corralation Io ecruintion

Por eant 7

$\mathbf{2}$

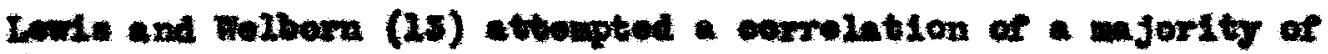

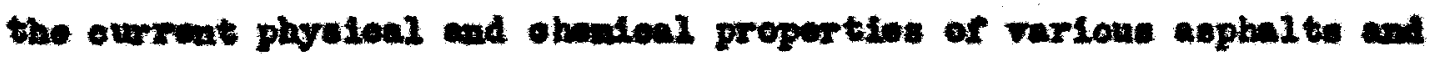


copoluded thet

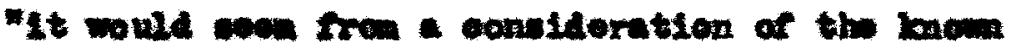

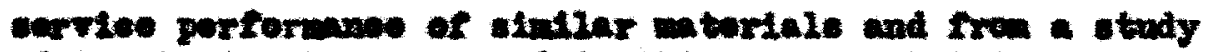
of tho vest dote prosonted in this ropert that thoes

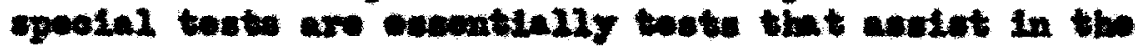
Leatifiention of woures or th nothod of prooestins or

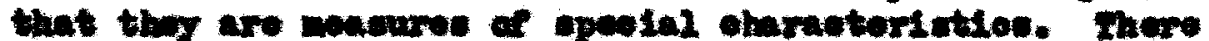

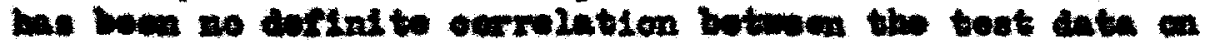

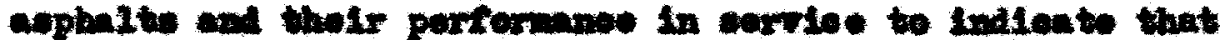

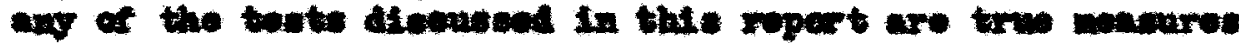

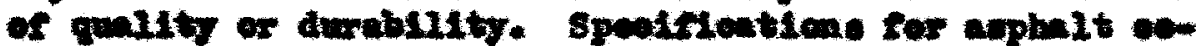

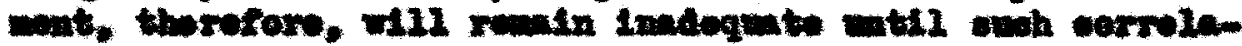

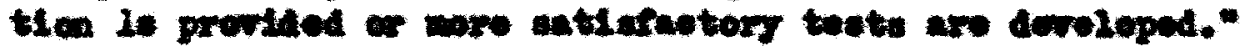

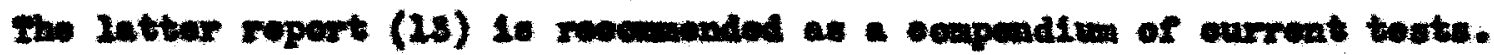

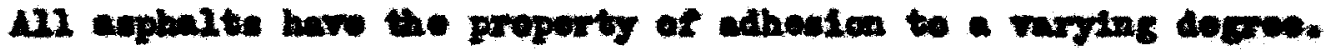

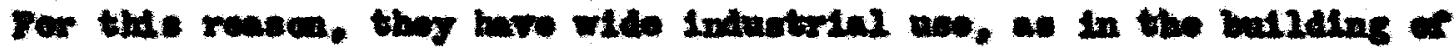

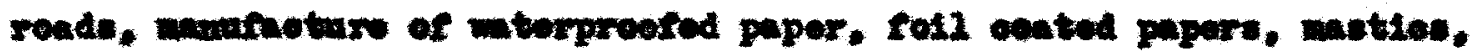

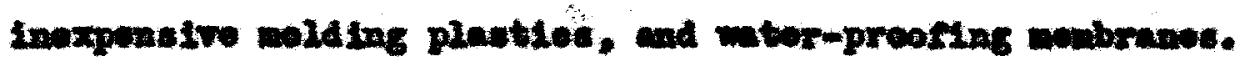

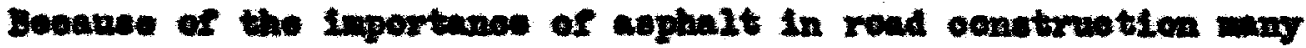

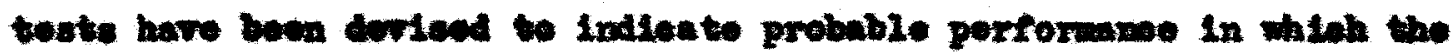

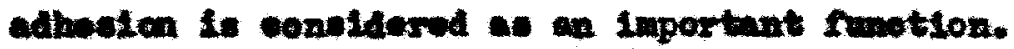

The Ilodel and Fiver (20) adbeston test in whioh aphalt ceated

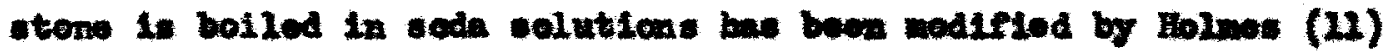

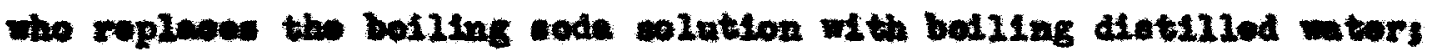

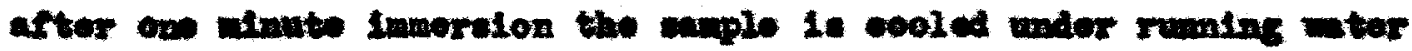

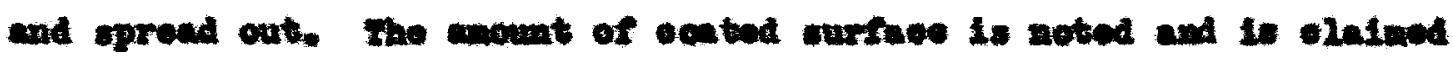
to be a manare of adpotion.

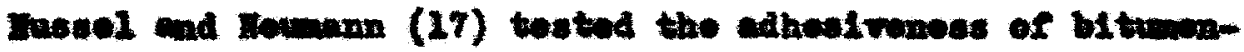

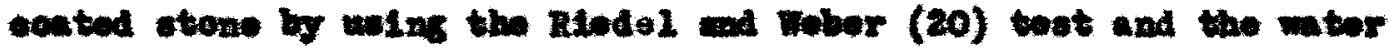

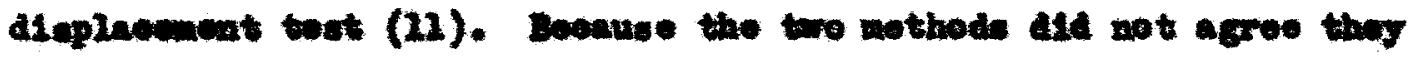
otreseod the importanes of the artuce proporties of the fl11er. 


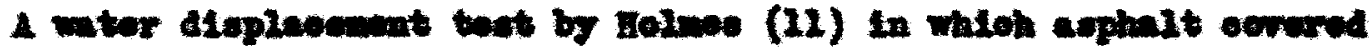

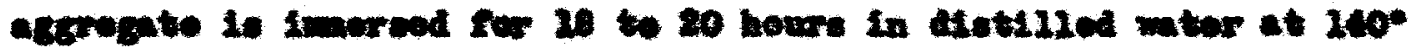

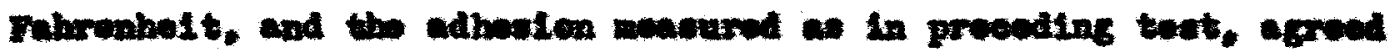
fardy well with the water balling tovt.

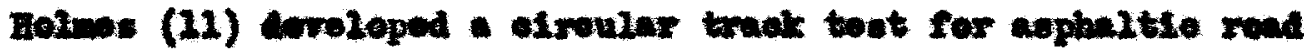

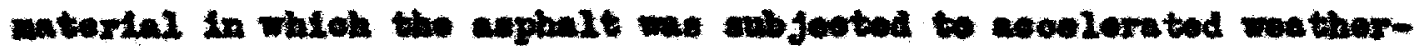

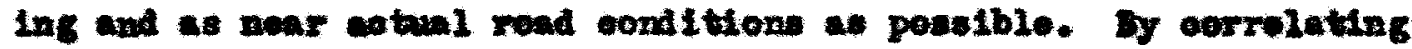

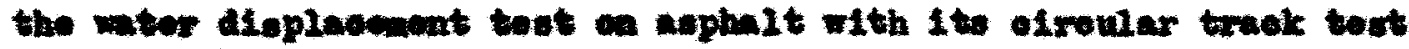

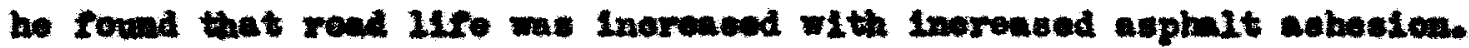

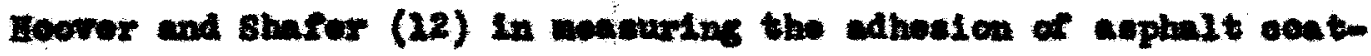

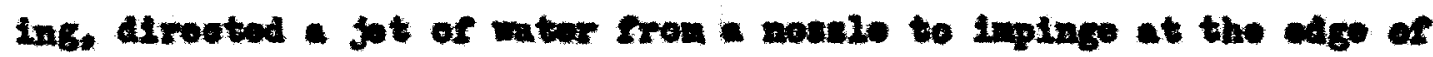

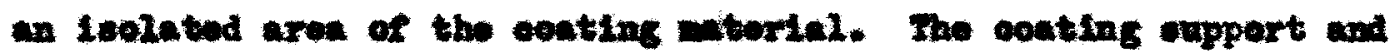
noxsle wore at an angle of about $4^{*}$.

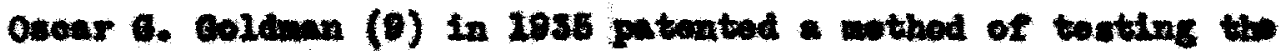

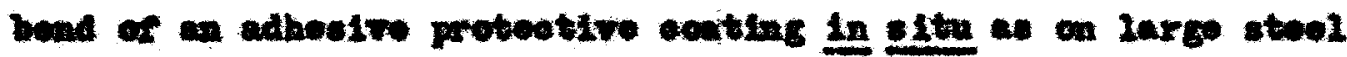
pipos. platss, and chapes. The wothed convisted in atripping the

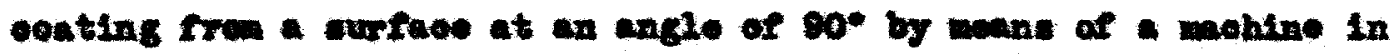
which the tores applied was roud on a enge.

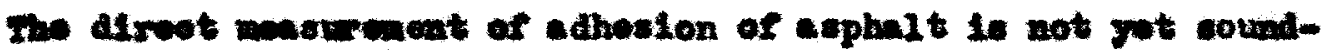

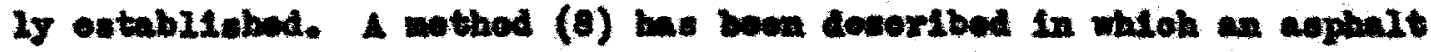

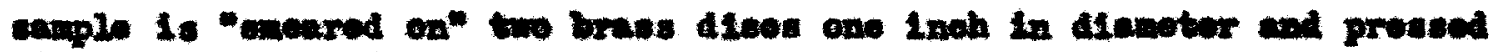

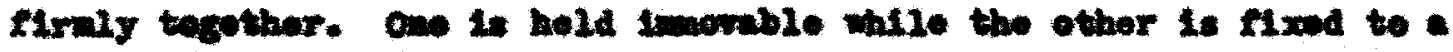

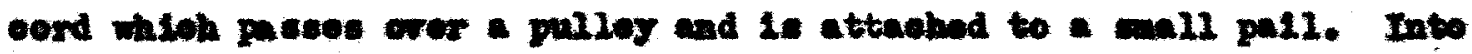
this pall shot are poured rogularly at a rato of 2,250 trone por minate ad the weight noted when the plates aro pulled apart at a taper- 


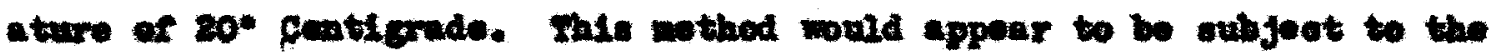

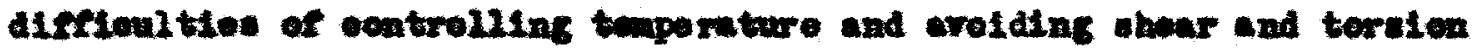
errocte on the sanple.

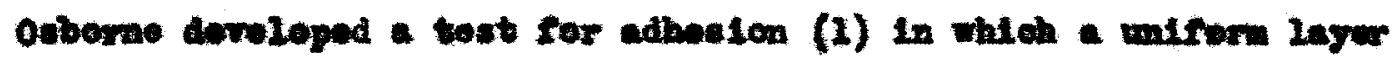

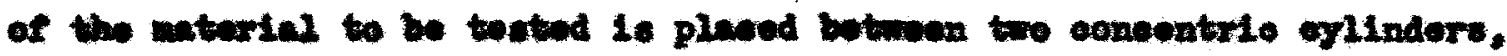

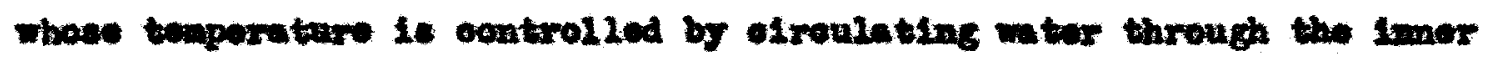

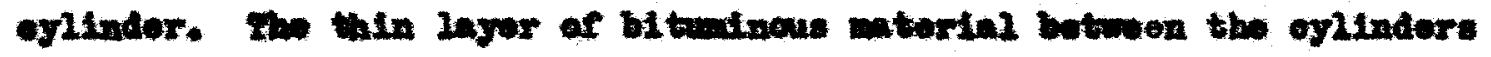

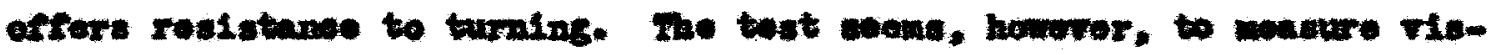
oosity rather than athosion.

Inotior nothad (2) is to welt the eapple of aaphalt inte a aplit

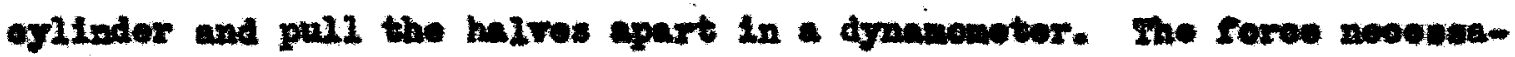

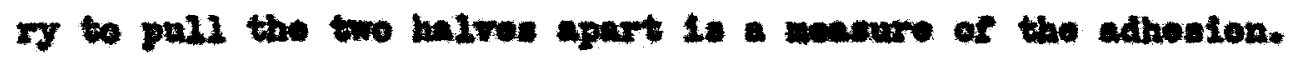

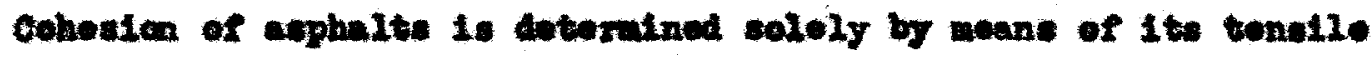
atrougth (2). This is roeorded on a tonseneter (I) and It equal to the

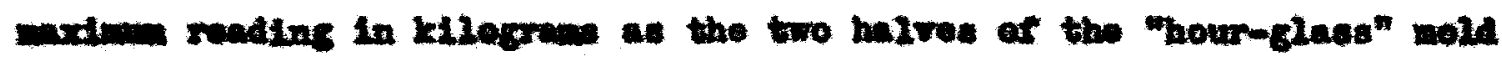
enparate. 
Ereanrout 


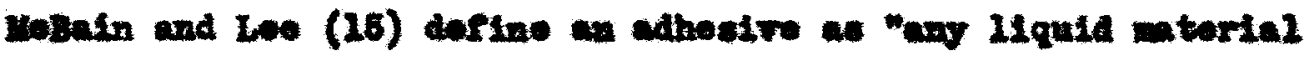

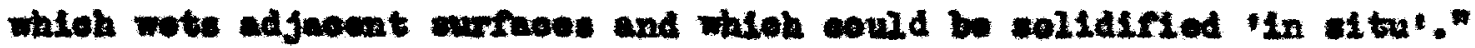
whe theory of edheelves deponds in part upen the hardeming of the

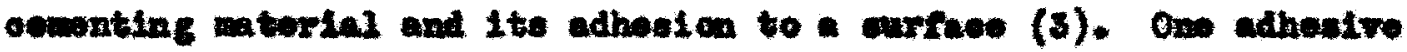

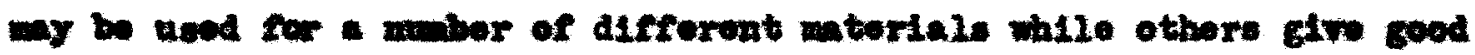
resalte only for opotal materiale.

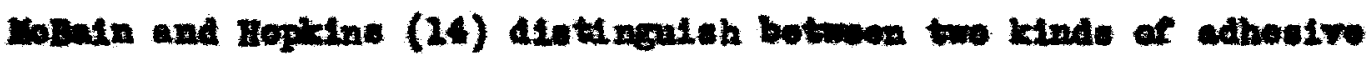

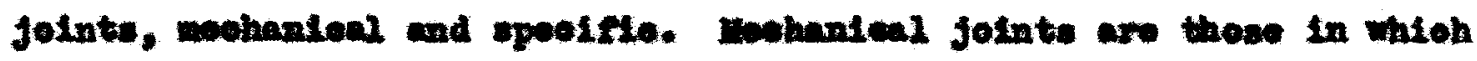

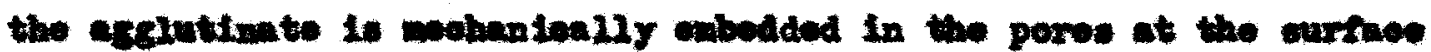

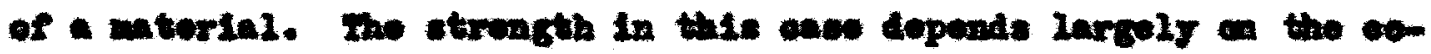

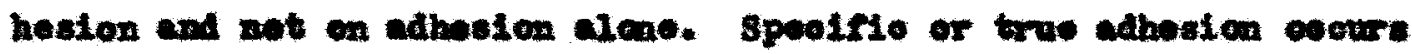

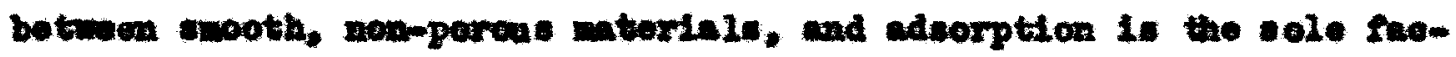
bor In this onae.

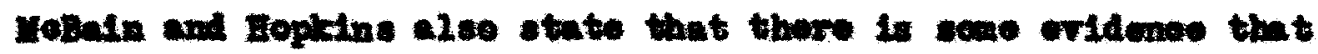

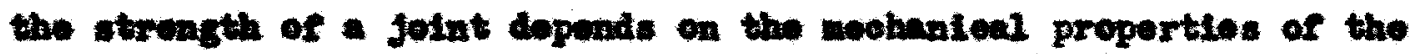

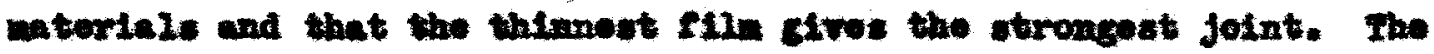

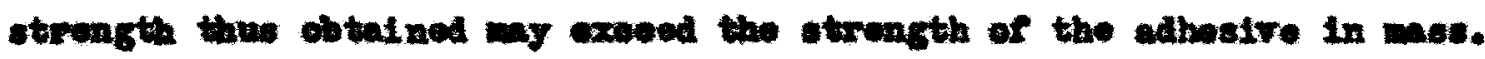

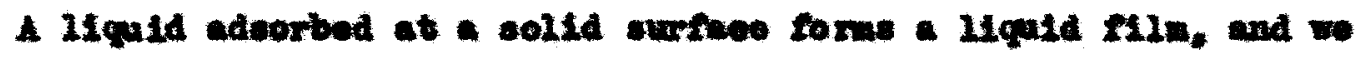
eny that the $21 \mathrm{gat}$ wote the selid (s).

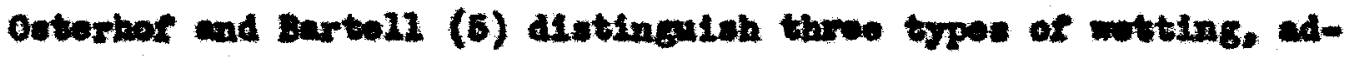
hostonal wotting, apreading wotting, and imoratonal woting. or

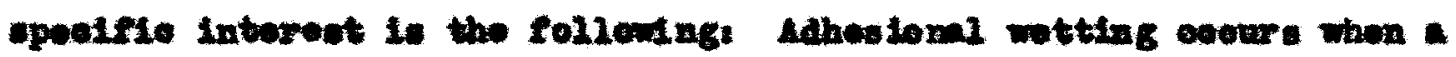

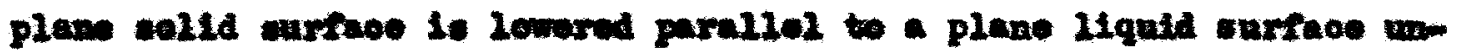

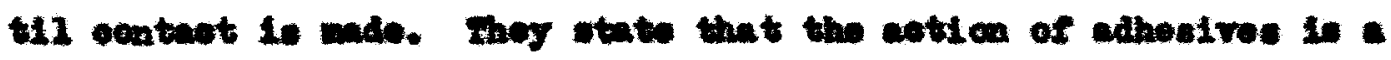

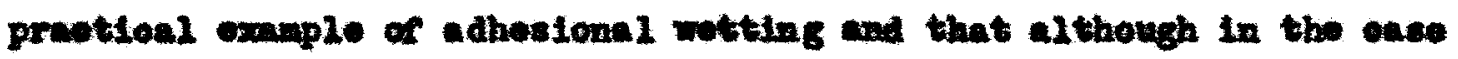




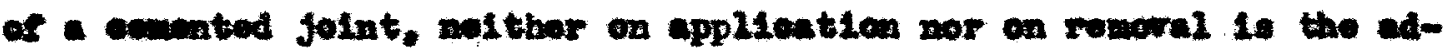

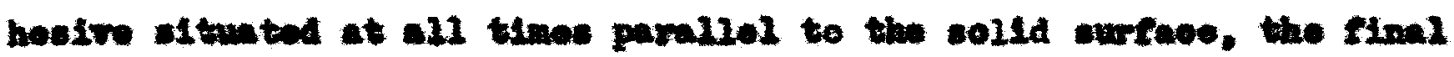

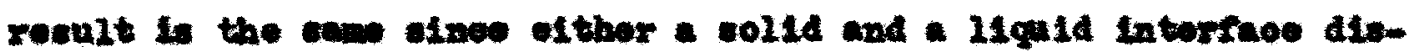

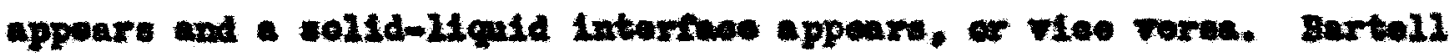

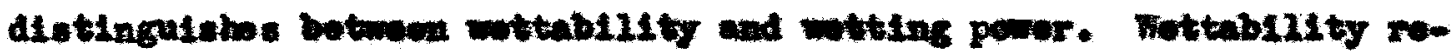

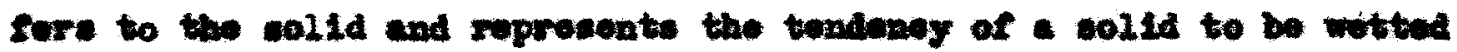
and it expresed by the ralue in exge of the tare $\left(s_{1}-s_{1}\right)$ :

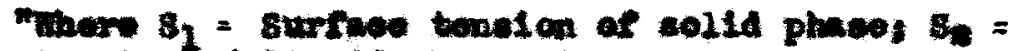

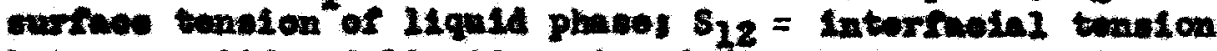
botwen colld and 11quid. si and of are for the colld and Ligula roepotively. the stro enorgies romining in their portion of the eolla-ligutd intertiov. The wn of si wa s. then oguila $s_{22}$. the Interthelal beneton of Nro onore et12L rosilent in the intertwoe."

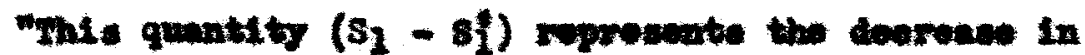

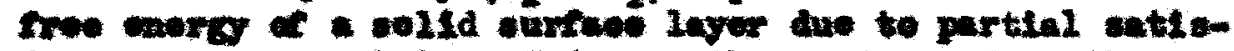

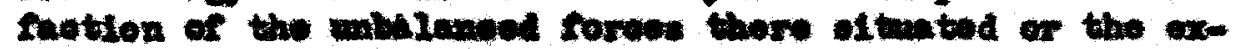

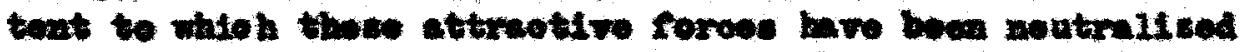

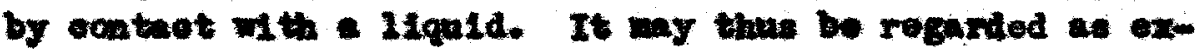

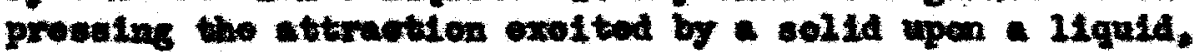
and tharesom the vouloney of the solld to fom 1 ta portion of alld-Liguld intertwee."

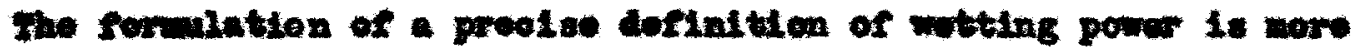

diteriont.

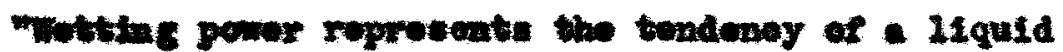
to wot a colld. but it eamot be se aimply expresend as in the focmer cace. based on aluklar rovioning to that used

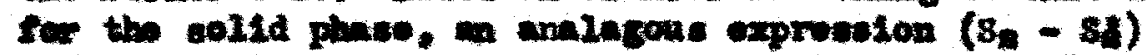

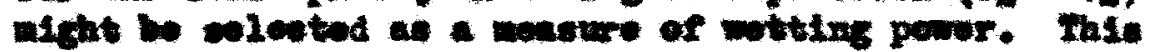

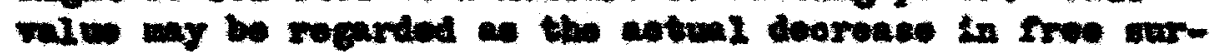

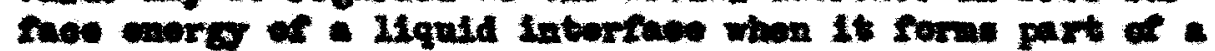

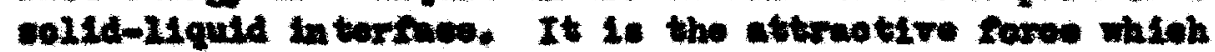

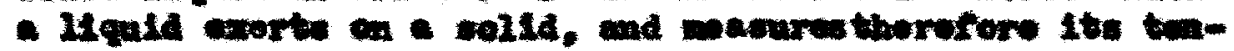
deagy to wot if whindored by other fuotore."

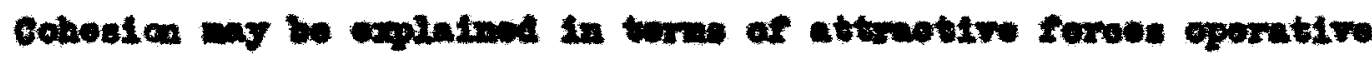

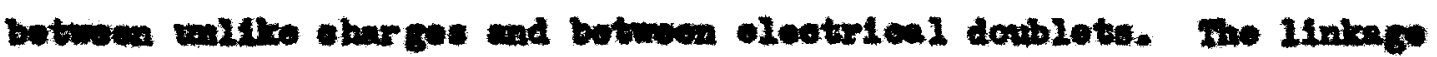




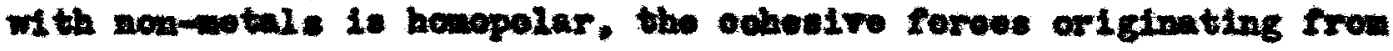

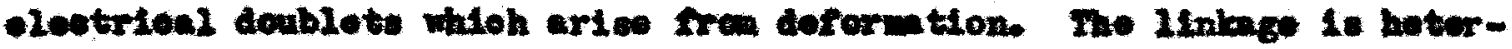

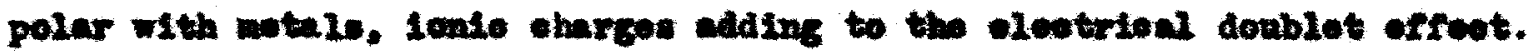

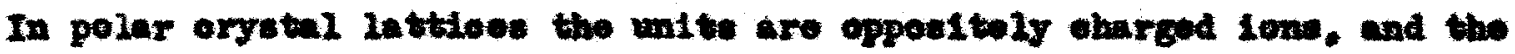
forees of eoheation vary as the Imorwe equare of the dietanes of separation prowided doformation of the elootronle obollo is about (28). Brend-

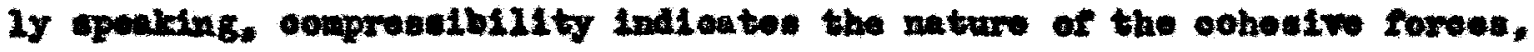

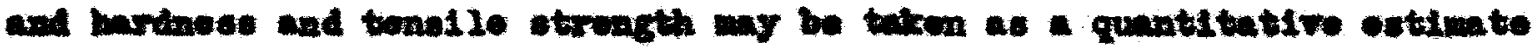
of thetr manitain.

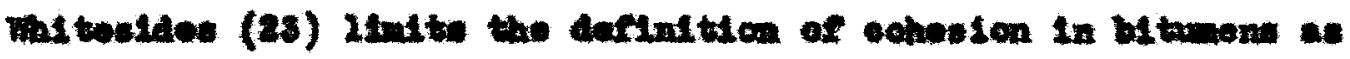

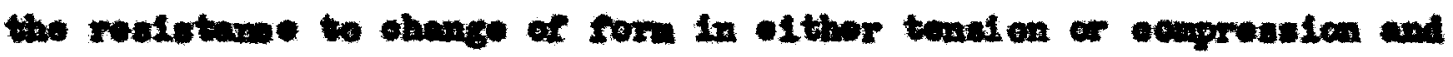

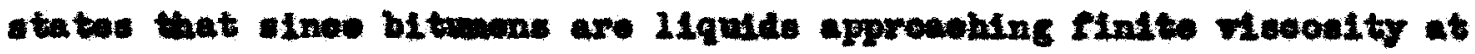

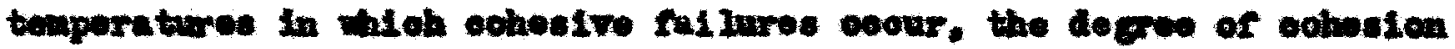

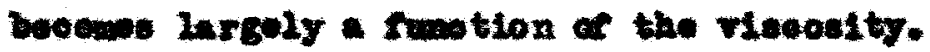


APRARARE 


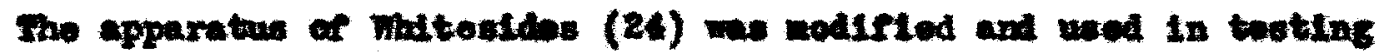

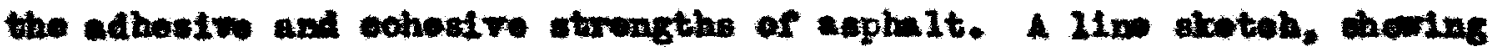

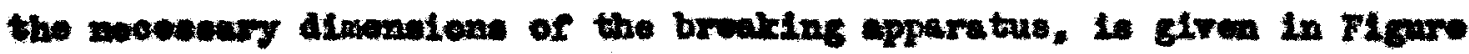
2. and a photograph of the apparatus sampletely wot to lo abown in Figre 29.

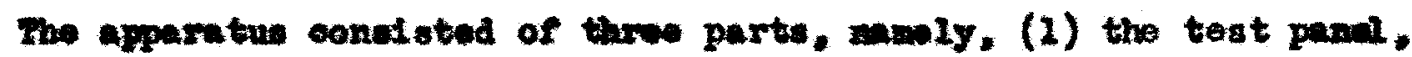
(2) a bod of controlling baperatare, and (8) a devieo for broaking the tort panele.

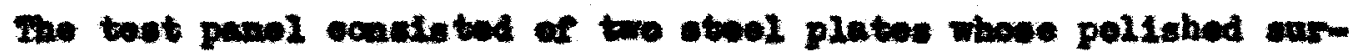

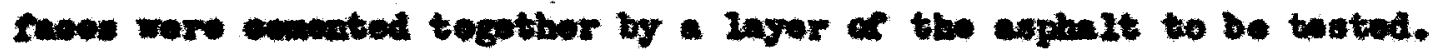

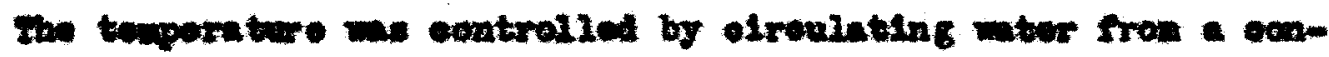

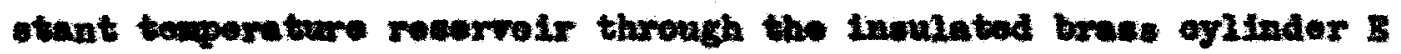

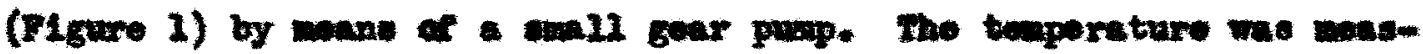

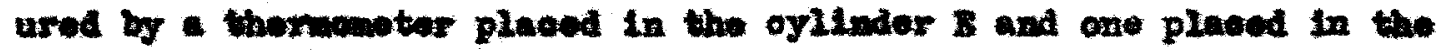

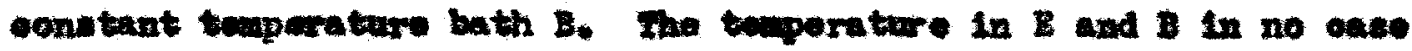
varled nore than $t$ Folumaholt.

The teat penel was breken apert by fixing the botton plate (the ocasontrio ring) and puiling the top otroviar plate any from It.

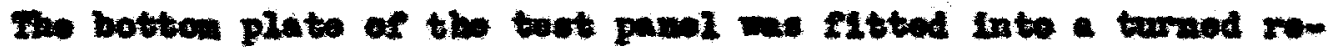

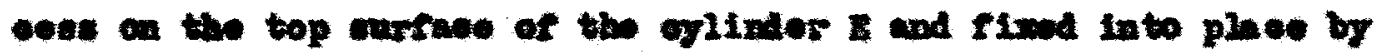

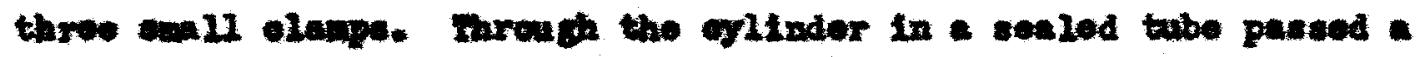

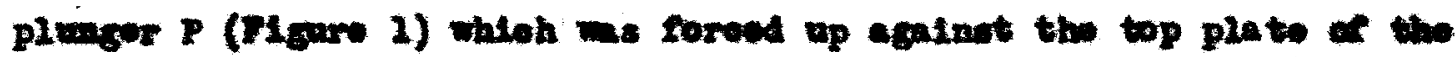

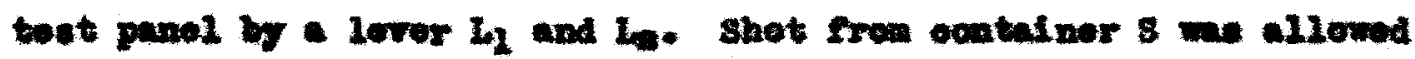

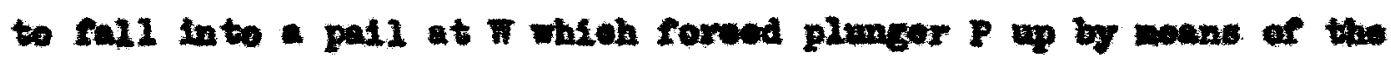
Lever $\mathrm{L}_{1}$ Le* 


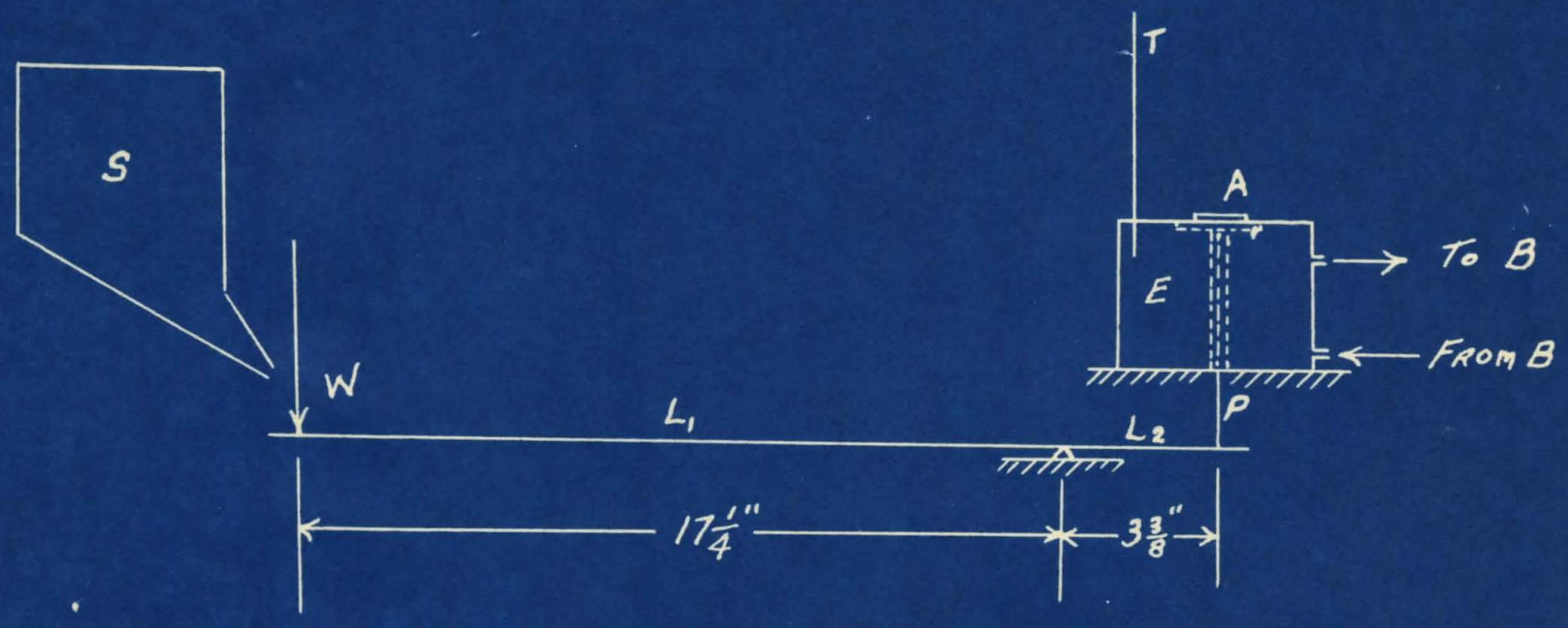

Figure /- Line Diagram of Apparatus 


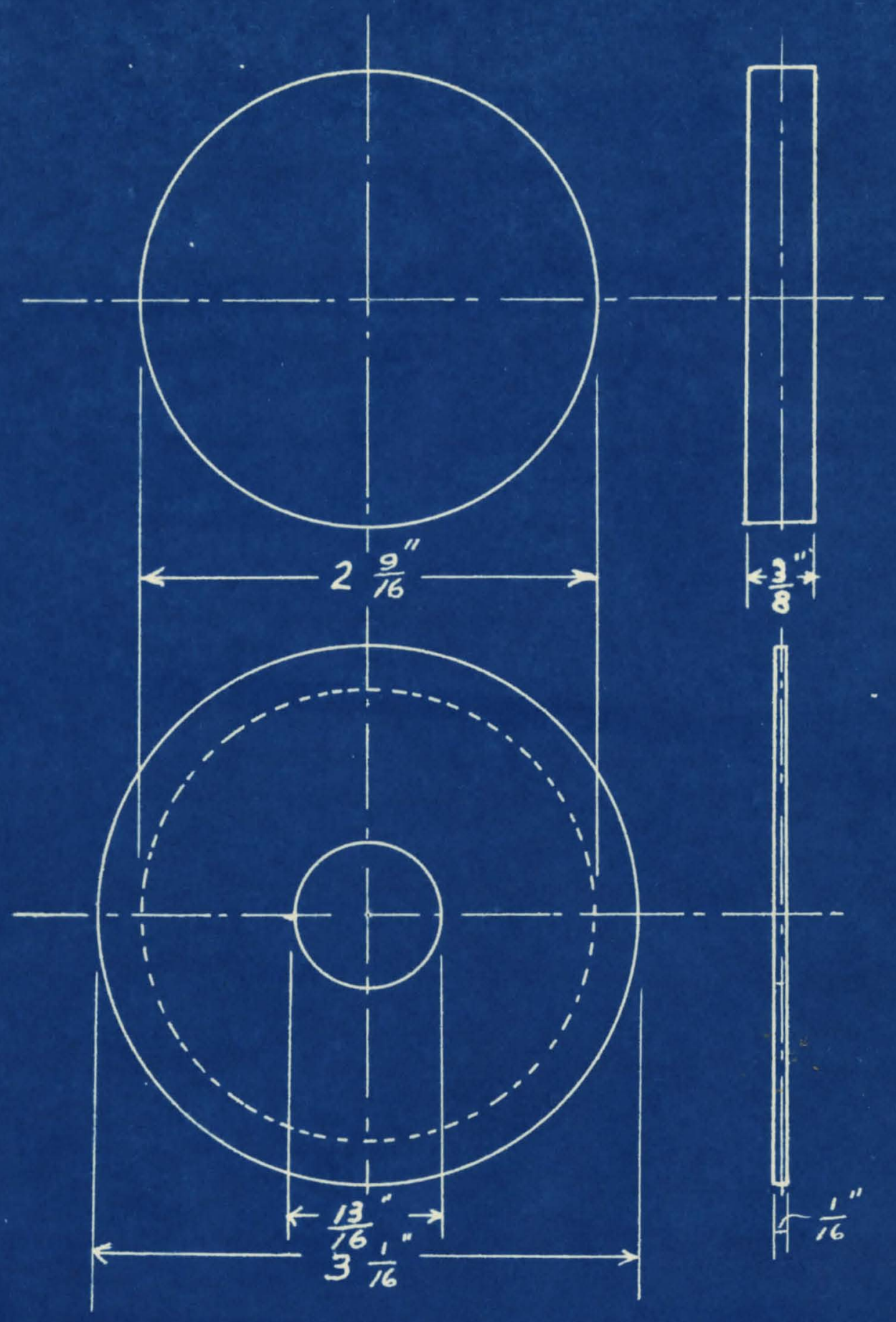

Figure la-Dlagram of Steel Plates of Test Panel 
Fhoxumet 


\section{Prevaration of samle}

Tho toel alsee are heated in an own to about 212 " Fohrowhelt or

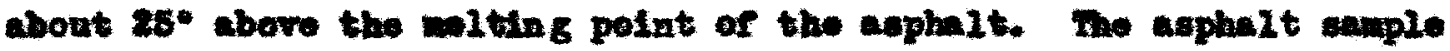

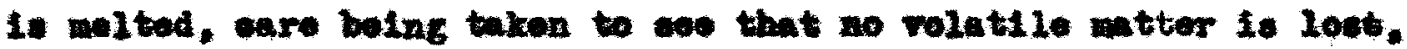
and a layer abat $1 / 10^{\circ}$ thi ol brushed on the botten plate. The top plate is tha taken from the oron and prosed dewa upen the Inyer of

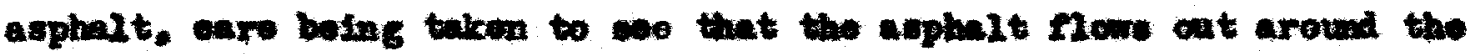
botten edge of the top plate. The anmple it then allowed to o001 and the exwees asphalt corrped off with a be epatula and then alewed if th eolvent.

\section{Uethod}

Tho water in the inner orlindor B and outor oylindrieal jeoket

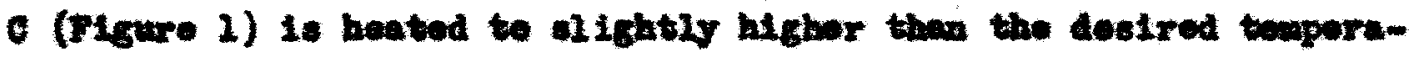

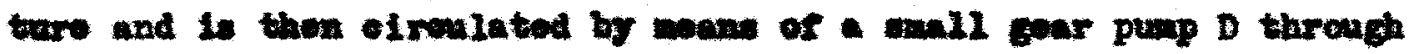
a brass oglindor $\mathrm{B}$. The test punols. after oooling. are pleced in

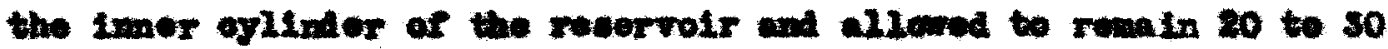

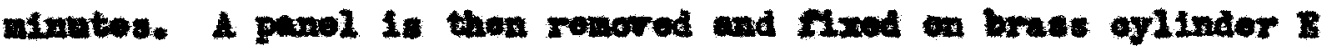

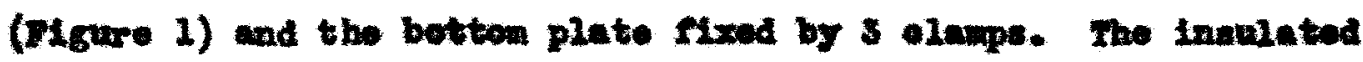

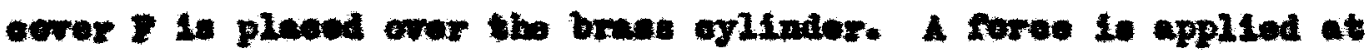

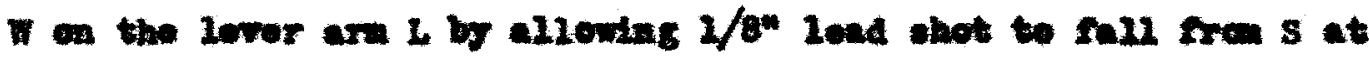

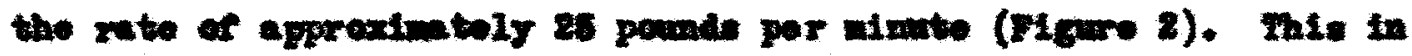

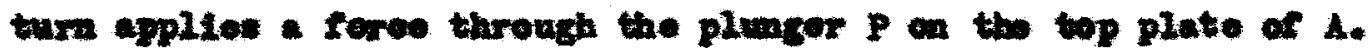

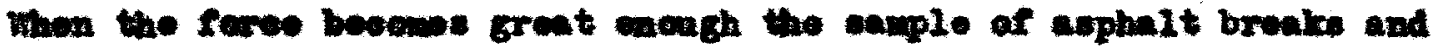

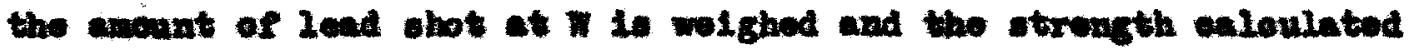
as hown on page 65. 
DAR AMD DEBULF 
AAXE I

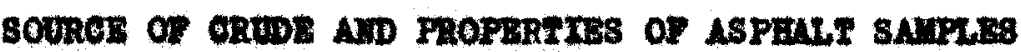

\begin{tabular}{|c|c|c|c|c|c|}
\hline semple & Hanfaebaror & souree of omdo* & Sortening & Proptration* & Duots216y \\
\hline $\mathbf{A}$ & 8 tandare 012 of IA. & Tonouelen (Lagund1Ln) & 166 & 82 & $\mathbf{s}$ \\
\hline $\mathbf{B}$ & standard osl of Le. & Tonowuelan (Laganillas) & 204 & $\mathbf{8 1}$ & 81 \\
\hline 6 & 2ome $011 \mathrm{os}$. & wrod sems Crudes & 207 & $\mathbf{s 8}$ & 26 \\
\hline $\mathbf{D}$ & xesen 01200 & South Amoriean omules & 207 & 24 & 24 \\
\hline $\mathbf{s}$ & torese 01200 & Mrod zorae Grudos & 168 & 86 & $\boldsymbol{H}_{\mathbf{z}}$ \\
\hline $\boldsymbol{F}$ & Burber sophat corp. & xomas & 108 & 28 & 8 \\
\hline 6 & Darbor Arphat corp. & Tomotuelen (Maraonibo) & 188 & $\mathbf{4}$ & 6 \\
\hline E & Darber Aophalt Garp. & Vonocnelen (Intreacbe) & 205 & 24 & $\mathbf{s}$ \\
\hline $\mathbf{I}$ & Berbor Anpbal toorp. & Tonorvelan (Mraed Lbo) & 168 & $\mathbf{2 2}$ & 6 \\
\hline$\sqrt{3}$ & sholl os2 co. & Pure Panuse Grude & 288 & 82 & 6 \\
\hline $\mathbf{x}$ & she2l 01200 & Pare sulfur Blux arude & $\mathbf{1 7 6}$ & 86 & 被 \\
\hline $\mathbf{L}$ & shorl on co. & Sulfur Blute-Tonosuelan Blend & 287 & 86 & 4 \\
\hline
\end{tabular}

opate so roelived fros munuraturer. 
WNis 1

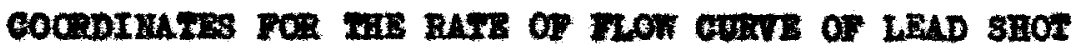

\begin{tabular}{|c|c|}
\hline Sevents & $\begin{array}{l}\text { Wolght of lowd shot } \\
\text { pomins }\end{array}$ \\
\hline 15 & 5.0 \\
\hline 80 & 11.9 \\
\hline 4 & 26.5 \\
\hline eo & 250 \\
\hline 7 & 30.6 \\
\hline 90 & $83_{*}$ \\
\hline 208 & 43.1 \\
\hline 220 & $\$ 6.0$ \\
\hline $\mathbf{2 8 5}$ & tes \\
\hline
\end{tabular}




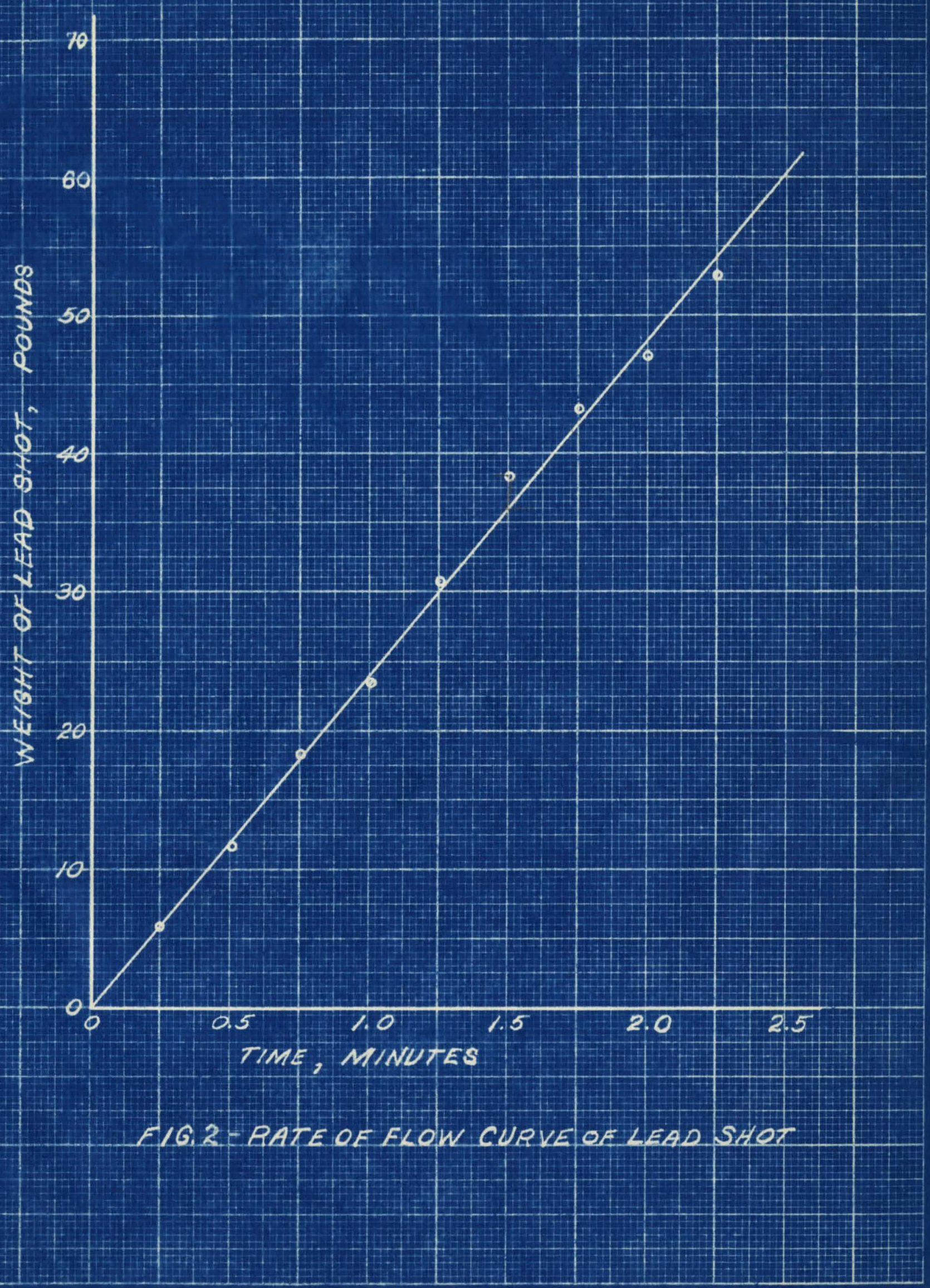


MATE II

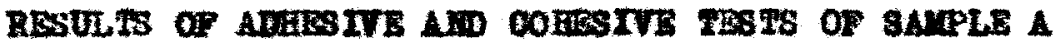

(Tanomalan. Lagmillas)

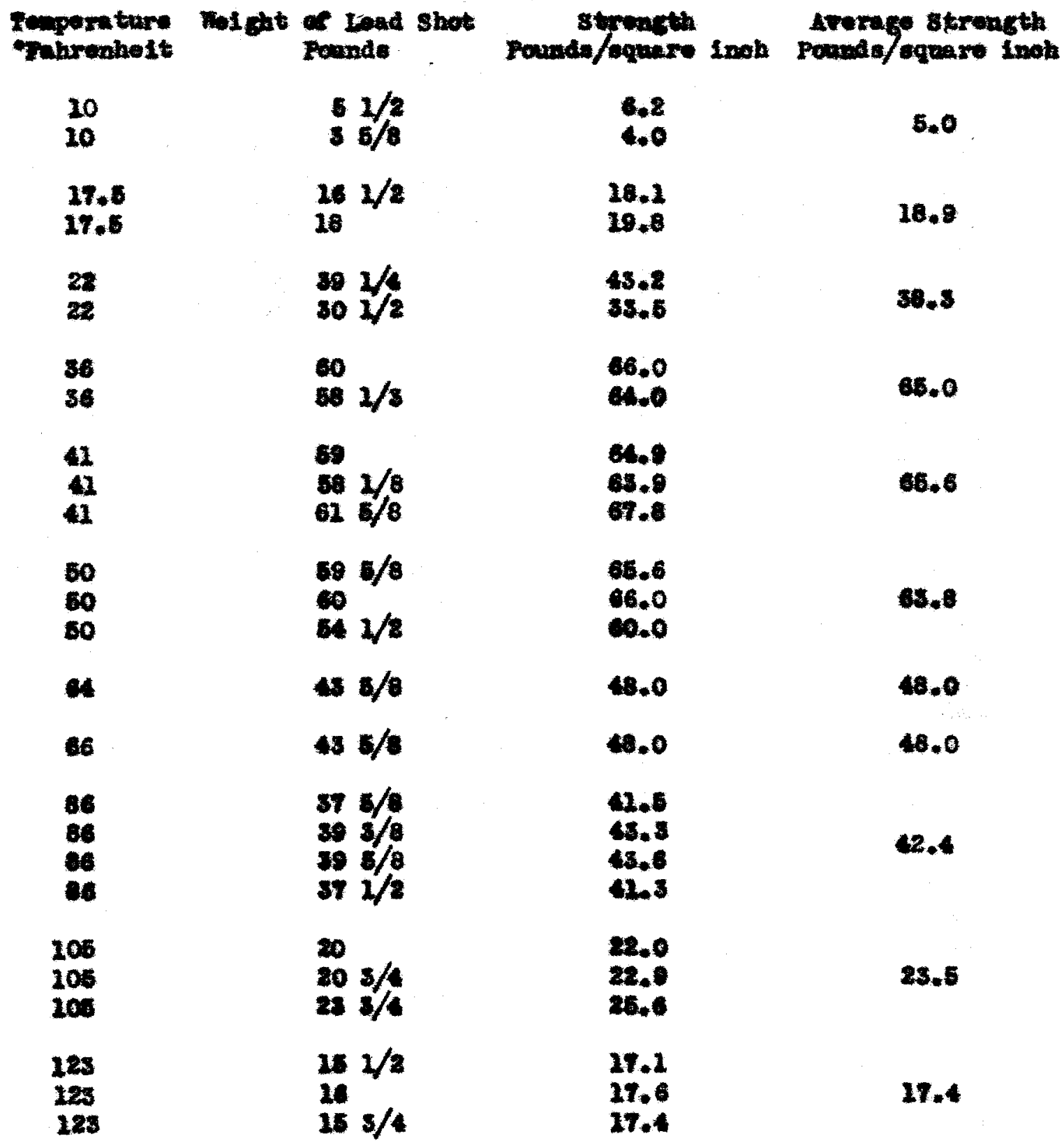




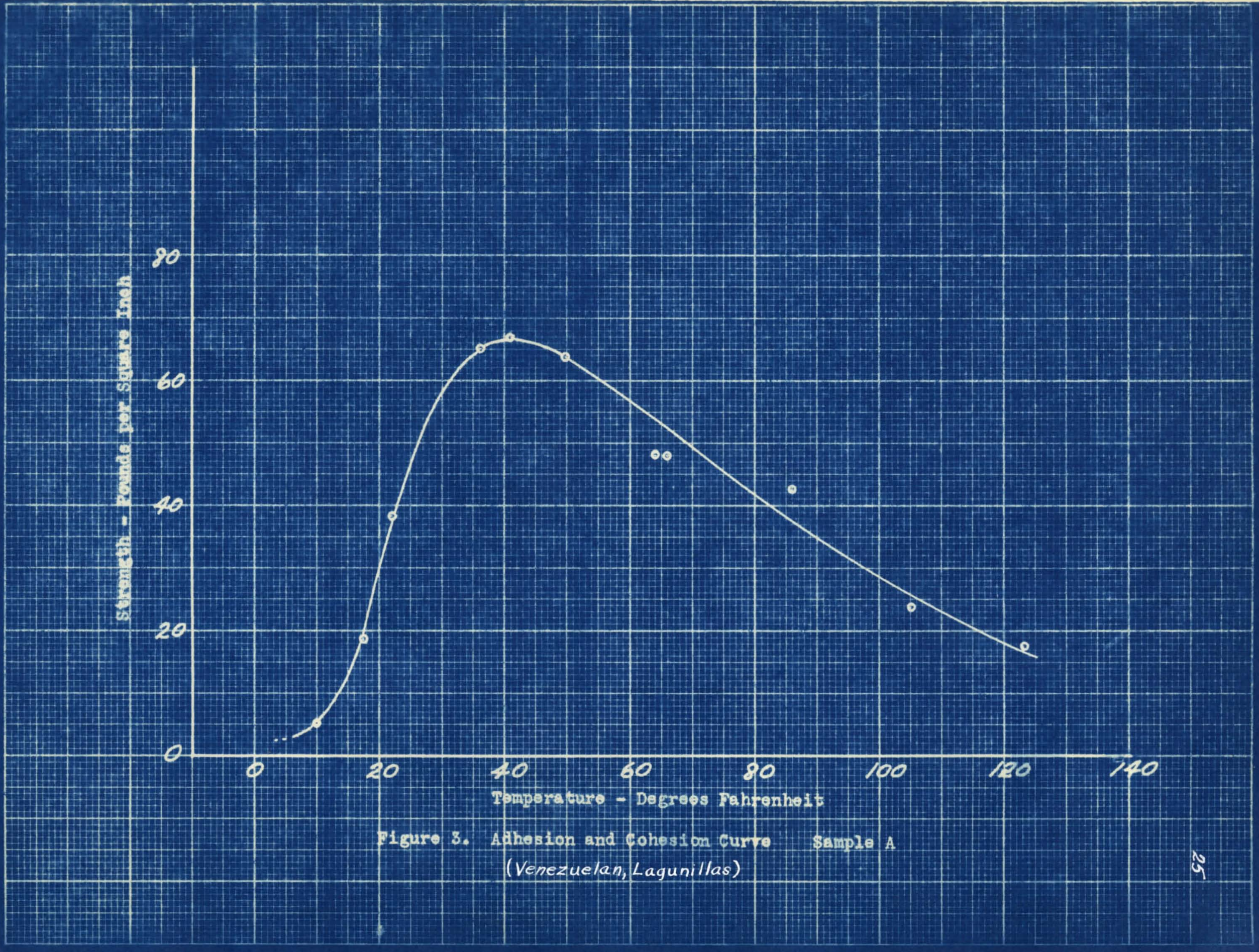


2ute II

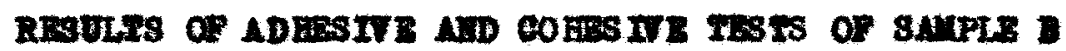

(Vonormelen, Laroutilas)

\begin{tabular}{|c|c|c|c|}
\hline $\begin{array}{l}\text { Tomperabure } \\
\text { Takreninots }\end{array}$ & $\begin{array}{l}\text { Wolght of Land shot } \\
\text { pounds }\end{array}$ & 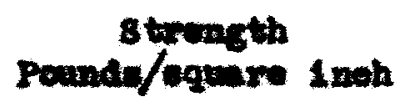 & $\begin{array}{l}\text { Arorage strangth } \\
\text { Ponade/equare inoh }\end{array}$ \\
\hline $\begin{array}{l}10 \\
10 \\
10\end{array}$ & $\begin{array}{l}26 \pi / 6 \\
26 \\
0\end{array}$ & $\begin{array}{l}17.6 \\
18.0 \\
22.0\end{array}$ & 18.1 \\
\hline $\begin{array}{l}28 \\
22\end{array}$ & $228 / 4$ & $\begin{array}{l}25.9 \\
26.7\end{array}$ & 25.3 \\
\hline $\begin{array}{l}36 \\
36 \\
36\end{array}$ & $\begin{array}{l}25 / 9 \\
305 / 4 \\
31 / 2\end{array}$ & $\begin{array}{l}35.9 \\
38.8 \\
3.7\end{array}$ & 88.6 \\
\hline $\begin{array}{l}50 \\
50 \\
50\end{array}$ & $\begin{array}{l}39 \\
39 \\
10\end{array}$ & $\begin{array}{l}4.8 \\
43.8 \\
4.0\end{array}$ & 45 \\
\hline 86 & $151 / 2$ & 80.0 & 60.0 \\
\hline 58 & $48 / 4$ & $\begin{aligned} 17.1 \\
6.0\end{aligned}$ & 9.6 \\
\hline 64 & $\begin{array}{l}45 / 9 \\
465\end{array}$ & $\begin{array}{l}14.0 \\
82.0\end{array}$ & 60.0 \\
\hline $\begin{array}{l}69 \\
69 \\
69 \\
69\end{array}$ & $\begin{array}{l}89 \\
401 / 4 \\
48 \\
41 / 4\end{array}$ & $\begin{array}{l}19.9 \\
4.2 \\
4.6 \\
4.7\end{array}$ & 48,5 \\
\hline $\begin{array}{l}86 \\
86 \\
86\end{array}$ & $\begin{array}{l}263 / 4 \\
293 / 4 \\
303 / 4\end{array}$ & $\begin{array}{l}20.6 \\
82.8 \\
38.8\end{array}$ & 32.0 \\
\hline $\begin{array}{l}105 \\
105 \\
106\end{array}$ & $\begin{array}{l}101 / 2 \\
208 / 6 \\
25 \quad 1 / 2\end{array}$ & $\begin{array}{l}21.6 \\
28.4 \\
26.9\end{array}$ & 28.3 \\
\hline $\begin{array}{l}128 \\
128 \\
128\end{array}$ & $\begin{array}{l}181 / 2 \\
181 / 4 \\
19\end{array}$ & $\begin{array}{l}20.4 \\
21.2 \\
20.9\end{array}$ & 20.8 \\
\hline
\end{tabular}




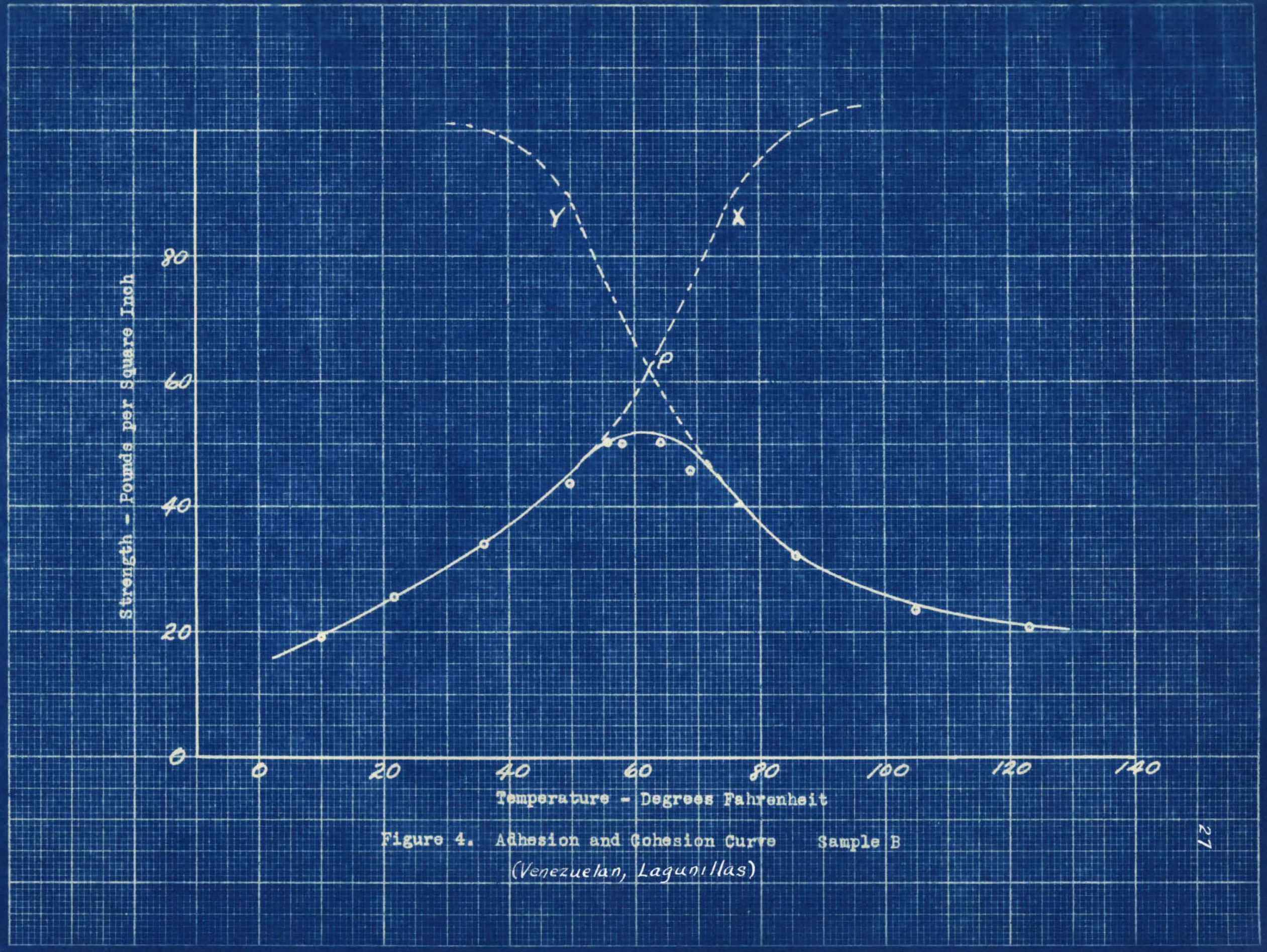




\section{Ans}

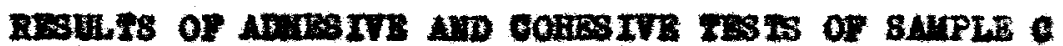

(rawa rowa Groded)

Temperaturo

Tabrenist

10.5

20.6

28

24

en

36

36

60

50

50

6

60

60

n

7

7

85

Q6

105

105

105

123

128

125
Wolght of Ind shot Pounale

$196 / 8$

29

2. $1 / 2$

$241 / 2$

26

38

$34 / 4$

3.) $1 /$

$31 / 6$

42

\$ $1 / 2$

45

47

36

3) $1 / 2$

$8 / 2$

30

$321 / 2$

a) $1 / 2$

$21 / 2$

$264 / 2$

18

$186 /$

$105 / \%$
Btrongth
Pandic/sequre inoh poundo/eguaro inoh

21.6

22.7

21. 7

24.8

27.0

27.5

26.4

36.2

37.7

36.8

38.8

10.8

46. 8

47.0

4.5

51.7

30.6

12.4

43.6

38.0

84.7

28.7

24.8

29.2

19.8

20,5

21.6
12.8

85.8

28.9

41.9

49.7

20.6 


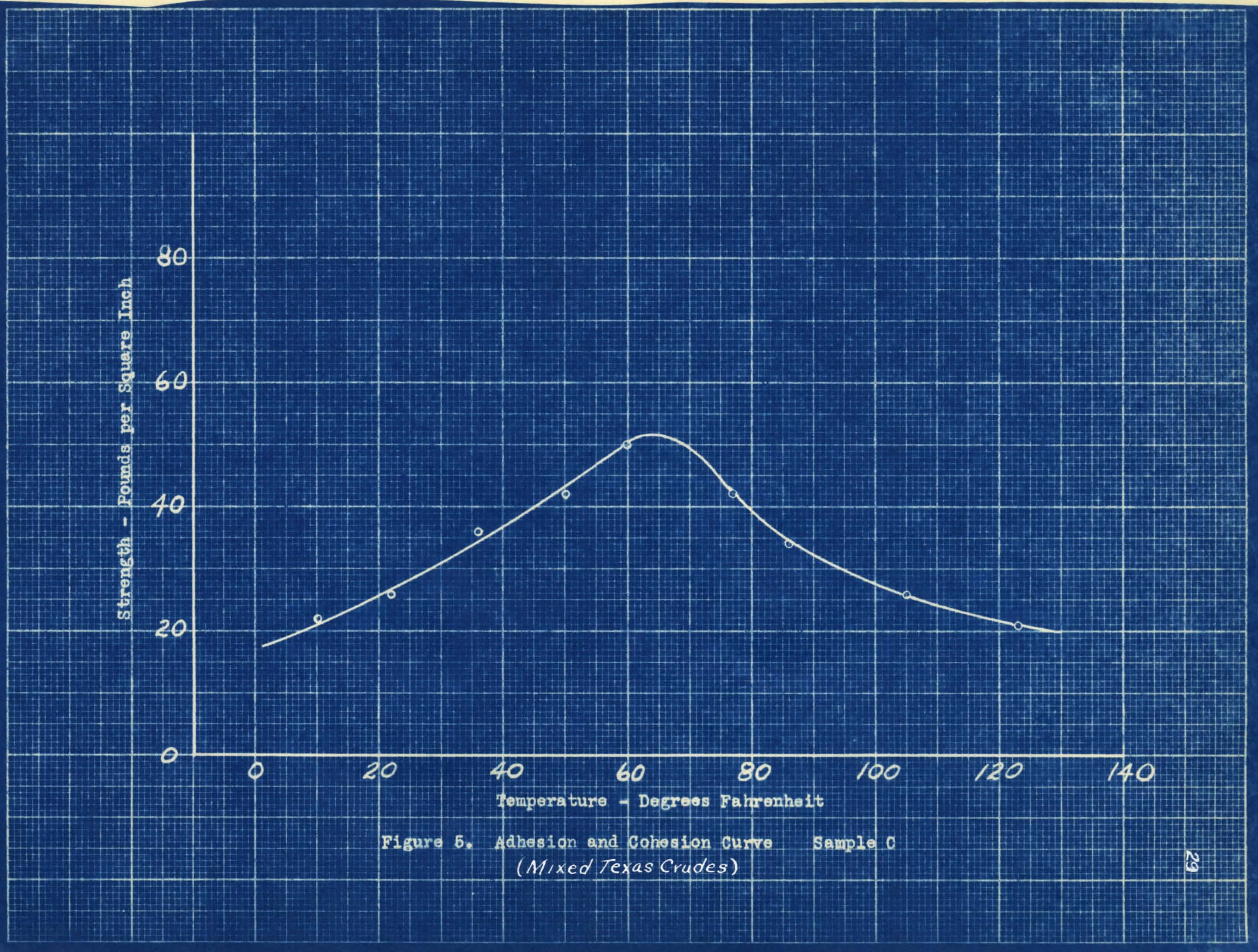




\section{vans $\mathbf{r}$}

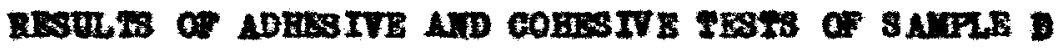
(South Amertean Crades)

\begin{tabular}{|c|c|c|c|}
\hline $\begin{array}{l}\text { Toupormtax } \\
\text { Thinrombeit }\end{array}$ & Whight of loed shot & Strangth & $\begin{array}{l}\text { Average strmath } \\
\text { Ponsilo/oguere inoh }\end{array}$ \\
\hline $\begin{array}{l}10.5 \\
10.6 \\
10.5\end{array}$ & $\begin{array}{l}105 / 6 \\
115 / 8 \\
137 / 8\end{array}$ & $\begin{array}{l}11.7 \\
22.7 \\
24=1\end{array}$ & 18.6 \\
\hline 28 & $251 / 4$ & 27.6 & 27.8 \\
\hline 86 & $\begin{array}{l}3 / 6 \\
37 / 6\end{array}$ & $\begin{array}{l}31.6 \\
20.4\end{array}$ & 38.0 \\
\hline $\begin{array}{l}50 \\
10 \\
50\end{array}$ & 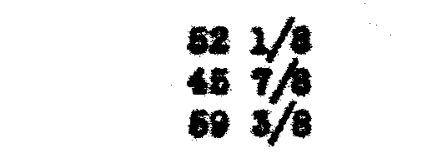 & $\begin{array}{l}67.5 \\
60.5 \\
65.2\end{array}$ & $8 \% .6$ \\
\hline $\begin{array}{l}60 \\
60\end{array}$ & $\frac{64}{69} 4 / 2$ & $\begin{array}{l}60.0 \\
64.0\end{array}$ & 62.5 \\
\hline $\begin{array}{l}10 \\
70 \\
70\end{array}$ & $\begin{array}{l}10 / 2 \\
801 / 2\end{array}$ & $\begin{array}{l}5.4 \\
6.0 \\
6.8\end{array}$ & 58.7 \\
\hline $\begin{array}{l}26 \\
06 \\
06 \\
60\end{array}$ & $\begin{array}{l}501 / 4 \\
38 \\
35 / 4 \\
35 / 6\end{array}$ & $\begin{array}{l}83.8 \\
39.2 \\
59.4 \\
40.3\end{array}$ & 37.6 \\
\hline $\begin{array}{l}105 \\
105 \\
105\end{array}$ & $\frac{26}{26} 1 / 2$ & $\begin{array}{l}20.9 \\
29.2 \\
31.0\end{array}$ & 27.3 \\
\hline $\begin{array}{l}125 \\
123 \\
128\end{array}$ & $\begin{array}{l}16 / 8 \\
28 \\
10\end{array}$ & $\begin{array}{l}17.1 \\
17.6 \\
20.8\end{array}$ & 10.6 \\
\hline
\end{tabular}




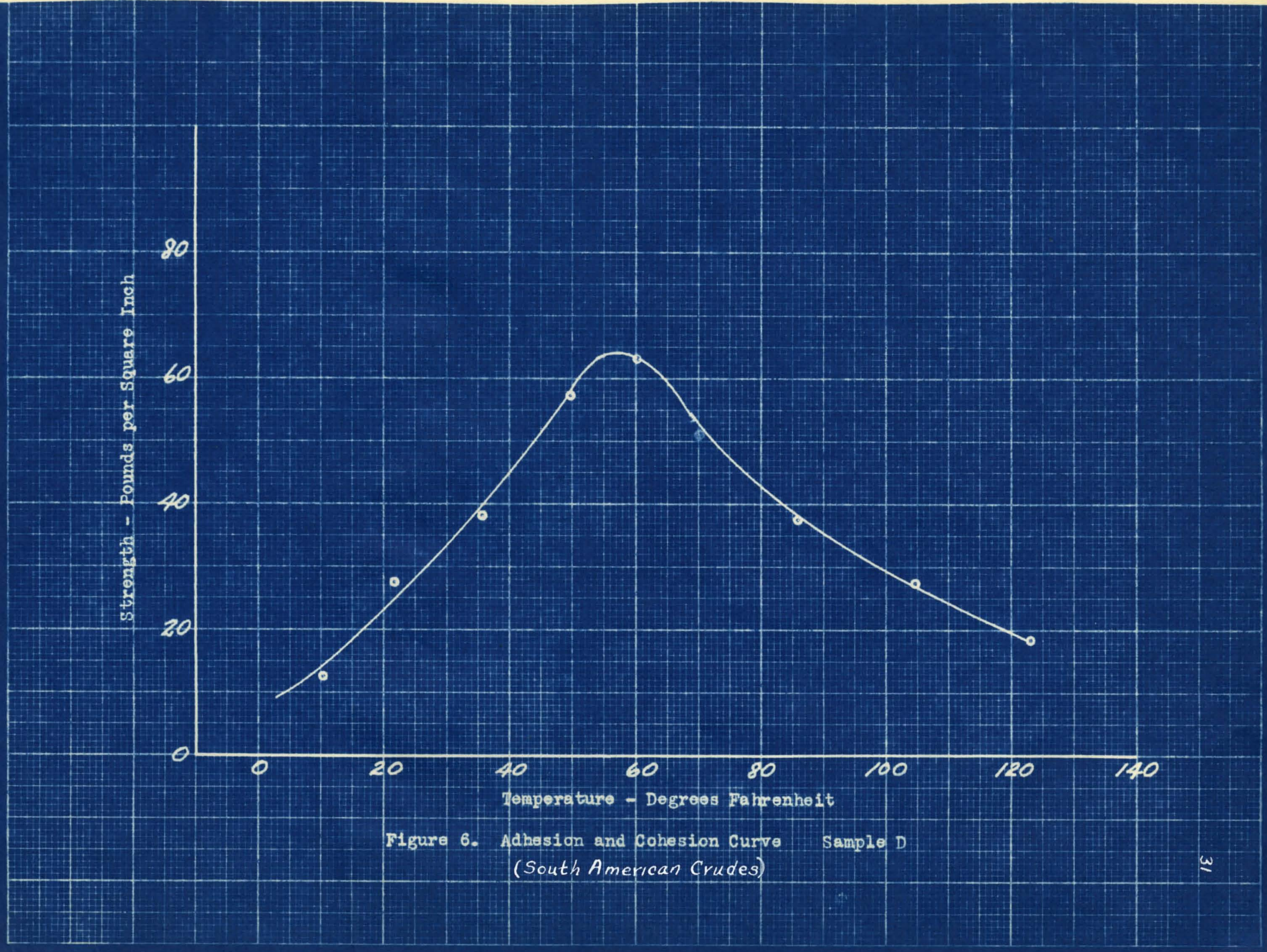


RESULTS O ADESTE AND COHESTV TESTS OP SATLB $\mathrm{F}$

(Irad Town Grodes)

\begin{tabular}{|c|c|c|c|}
\hline $\begin{array}{l}\text { Toporature } \\
\text { Pahronkelt }\end{array}$ & Folght of Load shot & $\begin{array}{l}\text { Strongth } \\
\text { Pownds/egumre inch }\end{array}$ & $\begin{array}{l}\text { Aroxege Strongth } \\
\text { Pounde/square inioh }\end{array}$ \\
\hline $\begin{array}{l}10.6 \\
10.5 \\
10.5\end{array}$ & $\begin{array}{l}1 / / \\
112 / / 6\end{array}$ & $\begin{array}{l}10.4 \\
12.4 \\
28.0\end{array}$ & 13,6 \\
\hline $\begin{array}{l}17.5 \\
17.5 \\
17.5\end{array}$ & $\begin{array}{l}291 / 2 \\
311 / 4 \\
341 / 4\end{array}$ & $\begin{array}{l}32.6 \\
34.2 \\
37.6\end{array}$ & 24.7 \\
\hline $\begin{array}{l}26 \\
26\end{array}$ & $\begin{array}{l}36 \\
59\end{array}$ & $\begin{array}{r}38.9 \\
42.9\end{array}$ & 42.4 \\
\hline $\begin{array}{l}36 \\
36 \\
36\end{array}$ & $\begin{array}{l}\text { os } 1 / 4 \\
501 / 4 \\
\text { so } 1 / 2\end{array}$ & $\begin{array}{l}65.3 \\
66.3 \\
65.5\end{array}$ & 65.4 \\
\hline $\begin{array}{l}10 \\
40 \\
40\end{array}$ & $\begin{array}{l}69 \\
69 \\
4 / 2\end{array}$ & $\begin{array}{l}64.9 \\
66.0 \\
60.9\end{array}$ & 66.9 \\
\hline $\begin{array}{l}48 \\
48 \\
48\end{array}$ & $\begin{array}{l}68 \\
881 / 2 \\
691 / 4\end{array}$ & $\begin{array}{l}68.8 \\
64.4 \\
65.8\end{array}$ & 64.6 \\
\hline $\begin{array}{l}68 \\
68 \\
68\end{array}$ & $\begin{array}{l}365 / 9 \\
305 / 8 \\
48 / 6\end{array}$ & $\begin{array}{r}10.4 \\
43.7 \\
48.8\end{array}$ & 43.3 \\
\hline $\begin{array}{l}n \\
77 \\
77\end{array}$ & $\begin{array}{l}315 / 4 \\
311 / 4 \\
325 / 2 \\
355\end{array}$ & $\begin{array}{l}33.8 \\
34.4 \\
36.8 \\
37.2\end{array}$ & 36.3 \\
\hline $\begin{array}{l}86 \\
86 \\
86\end{array}$ & $\begin{array}{ll}29 & 1 / 6 \\
30 & 5 / 8 \\
51 & 8 / 6\end{array}$ & $\begin{array}{l}32.0 \\
33.7 \\
3.6\end{array}$ & 38.4 \\
\hline $\begin{array}{l}206 \\
105 \\
106\end{array}$ & $\begin{array}{l}201 / 2 \\
811 / 4 \\
81 / 2\end{array}$ & $\begin{array}{l}22.6 \\
23.4 \\
28.1\end{array}$ & 24.7 \\
\hline $\begin{array}{l}123 \\
123 \\
125\end{array}$ & $\begin{array}{l}161 / 8 \\
171 / 8 \\
101 / 4\end{array}$ & $\begin{array}{l}17.1 \\
18.9 \\
21.2\end{array}$ & 19.0 \\
\hline
\end{tabular}




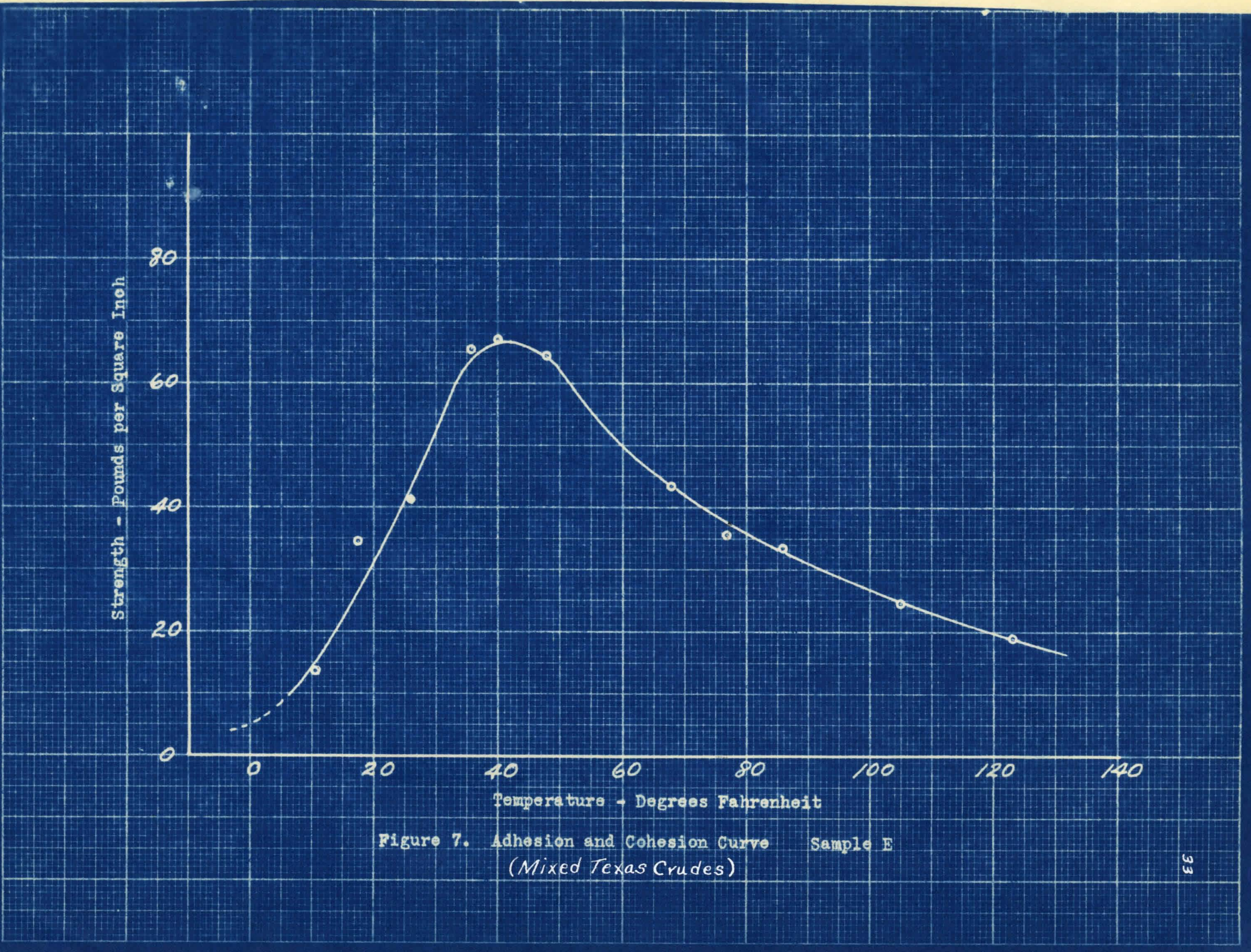




\section{Tants Vrrs}

\section{FESULTS OP ADHESTVE AMD COABS W TESTS OF SAMPLB $P$ \\ (Reane Crude)}

\begin{tabular}{|c|c|c|c|}
\hline $\begin{array}{l}\text { Tenpe rature } \\
\text { Tahreab it }\end{array}$ & $\begin{array}{l}\text { Wolght of lead shot } \\
\text { found }\end{array}$ & $\begin{array}{l}\text { Strength } \\
\text { Pounde/equere imh }\end{array}$ & $\begin{array}{l}\text { Arorage Strougth } \\
\text { Pound s/ aquare inoh }\end{array}$ \\
\hline $\begin{array}{l}17.5 \\
27.5 \\
17.5\end{array}$ & ${ }_{21}^{9} 1 / 6$ & $\begin{array}{r}2.6 \\
22.3 \\
13.2\end{array}$ & 11.8 \\
\hline $\begin{array}{l}36 \\
26\end{array}$ & $\begin{array}{l}19 \\
34\end{array}$ & $\begin{array}{l}21.6 \\
26.6\end{array}$ & 24.0 \\
\hline $\begin{array}{l}48 \\
48 \\
48\end{array}$ & $\begin{array}{l}35 \\
30 \quad 2 / 2 \\
311 / 2\end{array}$ & $\begin{array}{l}27.6 \\
33.5 \\
34.6\end{array}$ & $\mathbf{2 1 . 8}$ \\
\hline $\begin{array}{l}68 \\
68 \\
68\end{array}$ & $\begin{array}{l}423 / 9 \\
431 / 6 \\
438 / 6\end{array}$ & $\begin{array}{l}48.6 \\
47.5 \\
47.6\end{array}$ & 47.3 \\
\hline $\begin{array}{l}77 \\
77\end{array}$ & $\begin{array}{l}451 / 2 \\
161 / 4 \\
501 / 2\end{array}$ & $\begin{array}{l}50.0 \\
80.8 \\
55.6\end{array}$ & 52.3 \\
\hline $\begin{array}{l}86 \\
66 \\
66\end{array}$ & $\begin{array}{l}39 \\
108 / 4 \\
81 / 6\end{array}$ & $\begin{array}{l}42.9 \\
4.8 \\
48.3\end{array}$ & 45.3 \\
\hline $\begin{array}{l}105 \\
105 \\
205\end{array}$ & $\begin{array}{l}245 / 8 \\
267 / 8 \\
26\end{array}$ & $\begin{array}{l}27.1 \\
28.5 \\
28.6\end{array}$ & 28.1 \\
\hline $\begin{array}{l}128 \\
123 \\
123\end{array}$ & $\begin{array}{ll}10 & \\
10 & 1 / 2 \\
20 & 3 / 8\end{array}$ & $\begin{array}{l}20.9 \\
21.5 \\
2.4\end{array}$ & 21.6 \\
\hline
\end{tabular}




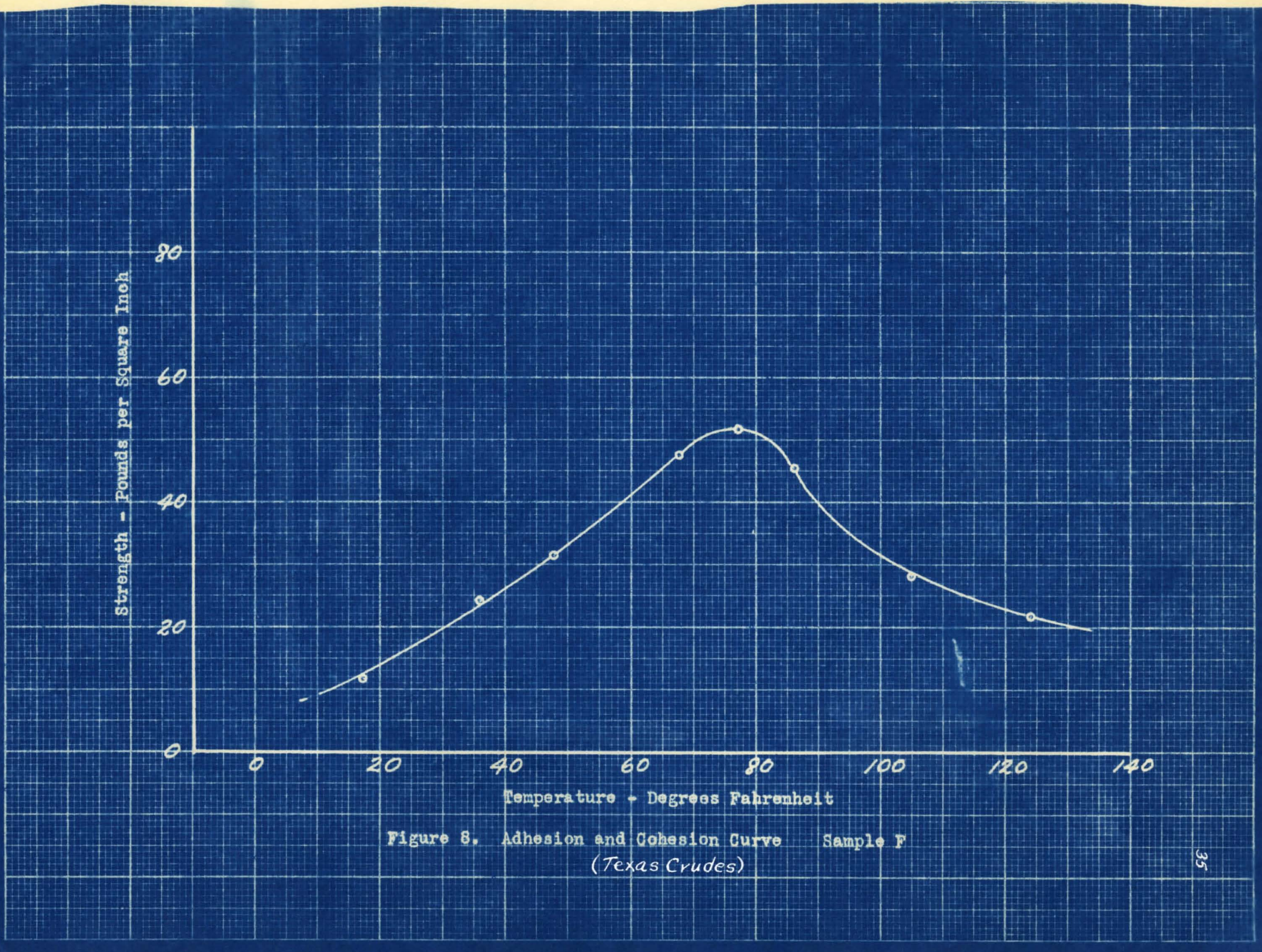


TABLE IX

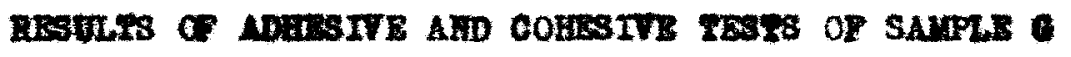

(Tenemulan, Numeatbo)

\begin{tabular}{|c|c|c|c|c|}
\hline Twperature & Folght & $\begin{array}{l}\text { of lead shot } \\
\text { Pound. }\end{array}$ & $\begin{array}{l}\text { Stasength } \\
\text { Poumde/Aquare inoh }\end{array}$ & $\begin{array}{l}\text { Lrerage strongth } \\
\text { Pounde equare inoh }\end{array}$ \\
\hline $\begin{array}{l}10.5 \\
10.6 \\
20.6\end{array}$ & & $\begin{array}{r}5 / 9 \\
55 / 4 \\
24 / 2\end{array}$ & $\begin{array}{r}9.6 \\
10.7 \\
16.0\end{array}$ & 12.0 \\
\hline $\begin{array}{l}27.6 \\
17.5 \\
17.6\end{array}$ & & $\begin{array}{l}163 / 4 \\
27 \mathrm{y} / 4 \\
267 / 6\end{array}$ & $\begin{array}{l}18.4 \\
50.0 \\
51.8\end{array}$ & 26.7 \\
\hline $\begin{array}{l}36 \\
86 \\
86\end{array}$ & & $\begin{array}{l}36 \\
48\end{array}$ & $\begin{array}{l}39.6 \\
49.0 \\
55.8\end{array}$ & 47.6 \\
\hline $\begin{array}{l}48 \\
48 \\
48\end{array}$ & & $\begin{array}{l}521 / 2 \\
685 / 6 \\
583 / 6\end{array}$ & $\begin{array}{l}57.8 \\
64.8 \\
64.3\end{array}$ & 02.1 \\
\hline 62 & & $\frac{11 / 2}{61} 1 / 2$ & $\begin{array}{l}62.8 \\
50.7\end{array}$ & 53.9 \\
\hline $\begin{array}{l}08 \\
68 \\
68\end{array}$ & $\therefore$ & $\begin{array}{l}17 \\
01 / 2 \\
61 / 2\end{array}$ & $\begin{array}{l}0.8 \\
4.8 \\
60.7\end{array}$ & 54.3 \\
\hline $\begin{array}{l}86 \\
86 \\
86\end{array}$ & & $\begin{array}{l}31 / 6 \\
358 / 6 \\
85 / 6\end{array}$ & $\begin{array}{l}3.4 \\
x+0 \\
37+0\end{array}$ & 36.1 \\
\hline $\begin{array}{l}105 \\
105 \\
105\end{array}$ & & $\begin{array}{l}213 / 0 \\
23 / 9 \\
835 / 0\end{array}$ & $\begin{array}{l}25.3 \\
24.4 \\
26.8\end{array}$ & $24 \cdot 6$ \\
\hline $\begin{array}{l}125 \\
125 \\
125\end{array}$ & & $\begin{array}{l}162 / 4 \\
186 / 6 \\
191 / 8\end{array}$ & $\begin{array}{l}17.0 \\
20.5 \\
22.2\end{array}$ & 19.8 \\
\hline
\end{tabular}




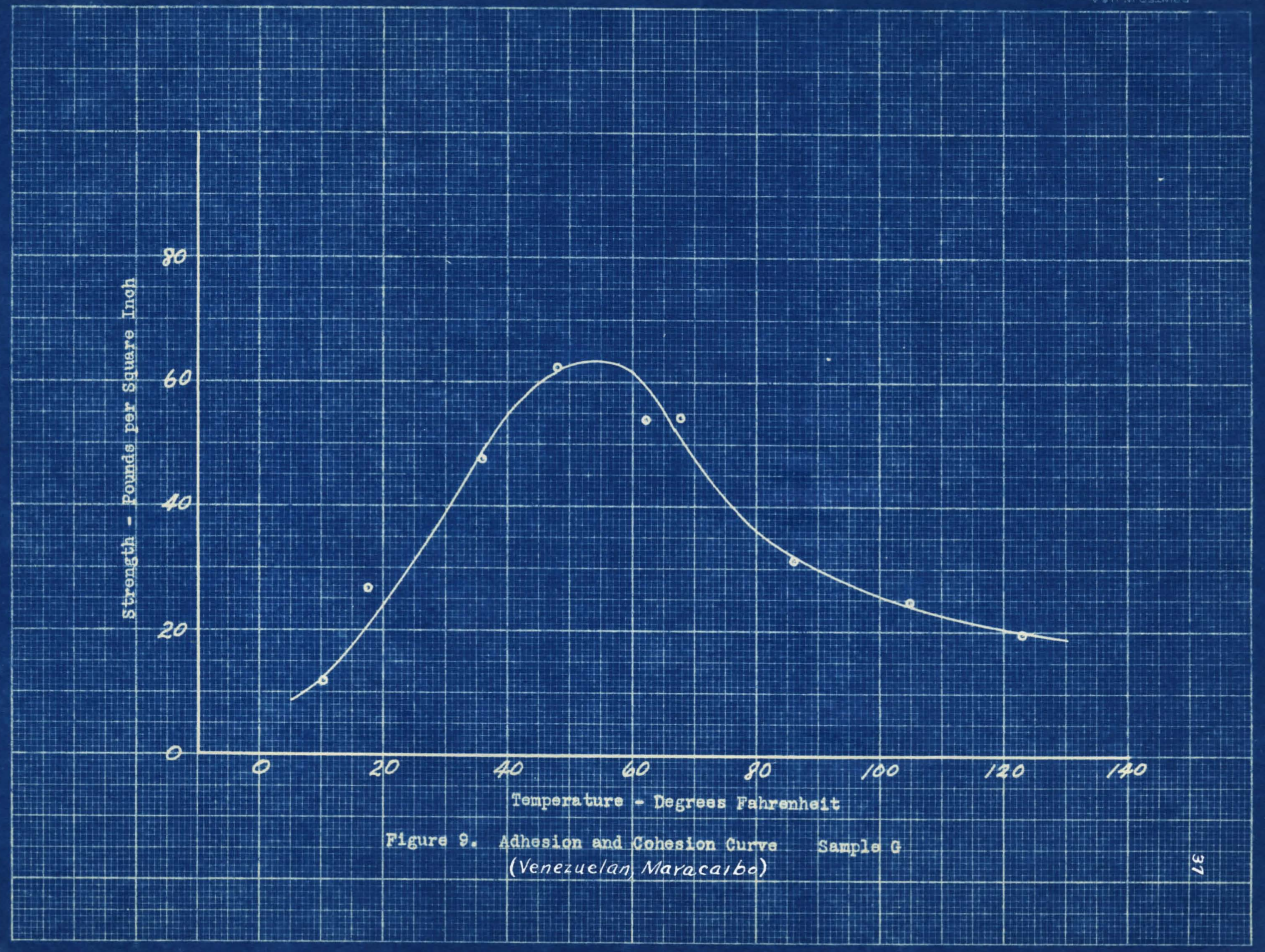




\section{RABLE $\mathbf{I}$}

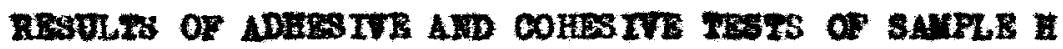

(Towosudan, Marmentbo)

\begin{tabular}{|c|c|c|c|c|}
\hline 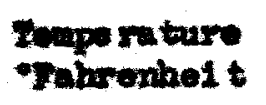 & Waight & $\begin{array}{l}\text { of Load shot } \\
\text { Pounds: }\end{array}$ & $\begin{array}{l}\text { Strongth } \\
\text { Pounde/equare thoh }\end{array}$ & $\begin{array}{l}\text { Arerage Strength } \\
\text { Powndequare ineh }\end{array}$ \\
\hline 18 & & $58 / 6$ & 4.0 & 4.0 \\
\hline $\begin{array}{l}20 \\
20\end{array}$ & & $9 / 6$ & $\begin{array}{r}7.0 \\
20.0\end{array}$ & 8.5 \\
\hline $\begin{array}{l}36 \\
36\end{array}$ & & $\begin{array}{r}93 / 4 \\
135\end{array}$ & $\begin{array}{l}10.7 \\
14.6\end{array}$ & 12.5 \\
\hline $\begin{array}{l}48 \\
48 \\
48\end{array}$ & & $\begin{array}{ll} & 15 / 4 \\
17 & 5 / 4 \\
21 & 3 / 4\end{array}$ & $\begin{array}{l}16.8 \\
19.5 \\
23.9\end{array}$ & 20.1 \\
\hline 66 & & 27 & 89.7 & 20.7 \\
\hline 60 & $\Rightarrow$ & $\begin{array}{l}30 \quad 1 / 8 \\
317\end{array}$ & $\begin{array}{l}33.7 \\
36.8\end{array}$ & 84.8 \\
\hline $\begin{array}{l}86 \\
86 \\
86\end{array}$ & & $\begin{array}{l}3 / 4 \\
401 / 2 \\
41 / 4\end{array}$ & $\begin{array}{l}59.4 \\
54.6 \\
69.7\end{array}$ & 51,2 \\
\hline $\begin{array}{l}105 \\
105 \\
105\end{array}$ & & $\begin{array}{l}267 / 8 \\
285 / 4 \\
34 / 8\end{array}$ & $\begin{array}{l}29.6 \\
32.6 \\
37.6\end{array}$ & 35.0 \\
\hline $\begin{array}{l}128 \\
128 \\
123\end{array}$ & & $\begin{array}{ll}19 & 1 / 4 \\
20 & 1 / 4 \\
2 & 1 / 2\end{array}$ & $\begin{array}{l}21.2 \\
28.3 \\
26.0\end{array}$ & 28.6 \\
\hline
\end{tabular}




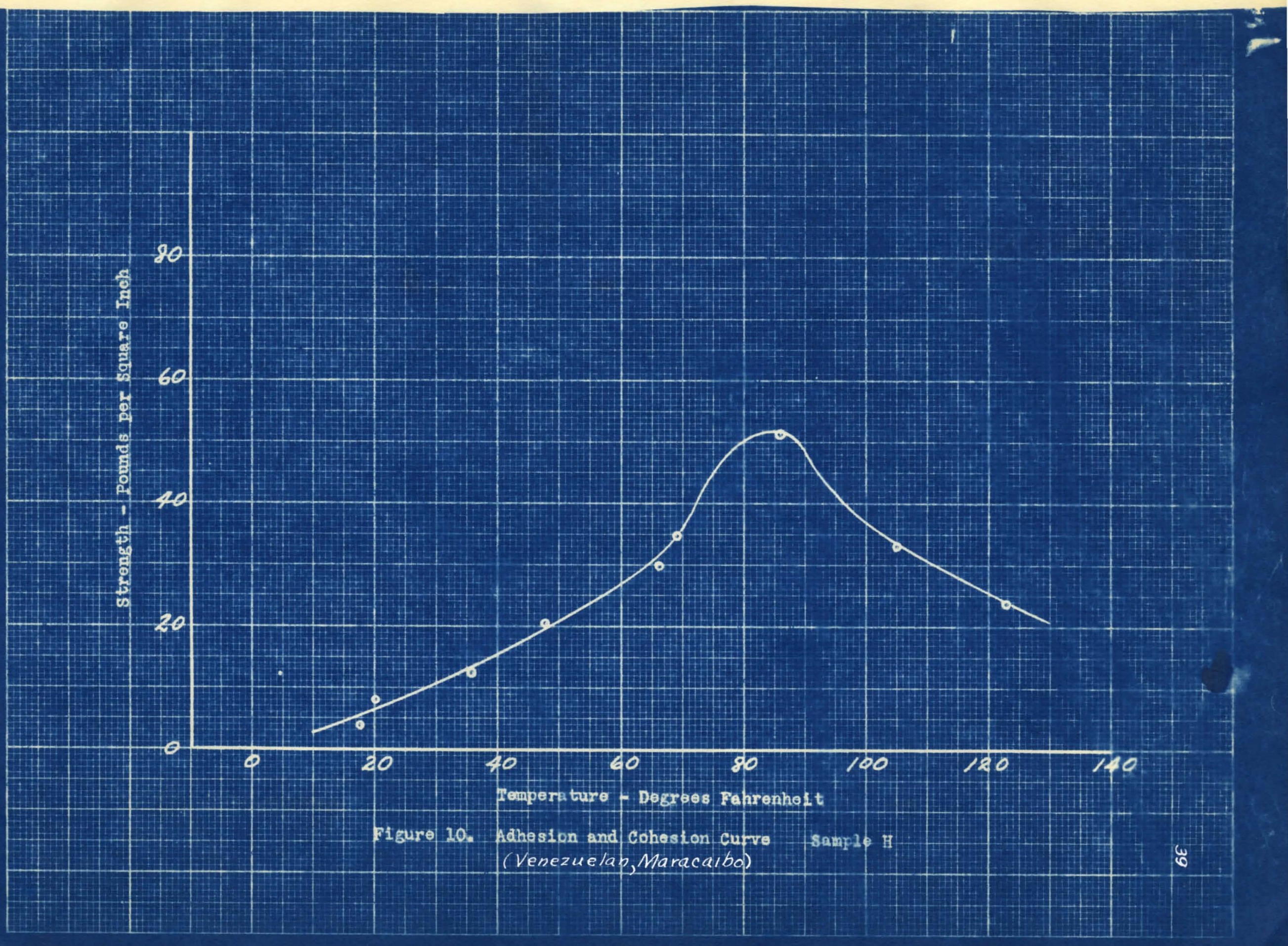


$\operatorname{sun} \mathbf{x}$

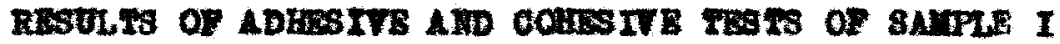

(Vonomelan, Henealbo)
\end{abstract}

\begin{tabular}{|c|c|c|c|}
\hline $\begin{array}{l}\text { Daperebure } \\
\text { Pahrenheit }\end{array}$ & $\begin{array}{l}\text { Welght of Lead shot } \\
\text { Poruds }\end{array}$ & $\begin{array}{l}\text { 8trongth } \\
\text { Pounde/sgure inoh }\end{array}$ & $\begin{array}{l}\text { Averuge sbromgth } \\
\text { Pomed aquare inoh }\end{array}$ \\
\hline $\begin{array}{l}8.5 \\
8.5 \\
8.5\end{array}$ & $\begin{array}{c}5 \\
142 / 8\end{array}$ & $\begin{array}{r}5.5 \\
6.5 \\
16.5\end{array}$ & 0.8 \\
\hline $\begin{array}{l}15.5 \\
25.5\end{array}$ & $\begin{array}{rl}15 & 1 / 2\end{array}$ & $\begin{array}{l}10.2 \\
17.0\end{array}$ & 23.6 \\
\hline $\begin{array}{l}37 \\
37 \\
37\end{array}$ & $\begin{array}{l}247 / 8 \\
281 / 8 \\
277 / 8\end{array}$ & $\begin{array}{l}27.4 \\
28.7 \\
30.7\end{array}$ & 20.9 \\
\hline $\begin{array}{l}49 \\
49\end{array}$ & $\begin{array}{l}41 / 4 \\
521 / 4\end{array}$ & $\begin{array}{l}47.6 \\
5.5 .6\end{array}$ & 52.0 \\
\hline $\begin{array}{l}50 \\
50\end{array}$ & 49 & $\begin{array}{l}63.9 \\
66.1\end{array}$ & 55.0 \\
\hline $\begin{array}{l}58 \\
68\end{array}$ & $\begin{array}{l}+1 / 2 \\
-51 / 2\end{array}$ & $\begin{array}{l}60.0 \\
02.2\end{array}$ & $61 \cdot 1$ \\
\hline 60 & 60 & 4.9 & 64.9 \\
\hline $\begin{array}{l}68 \\
68 \\
68\end{array}$ & $\begin{array}{l}49 \\
513 / 4 \\
53 / 4\end{array}$ & $\begin{array}{l}65.9 \\
67.0 \\
60.7\end{array}$ & 57.2 \\
\hline $\begin{array}{l}96 \\
88\end{array}$ & 41 & $\frac{45.1}{47.3}$ & 46.2 \\
\hline $\begin{array}{l}105 \\
105 \\
105\end{array}$ & $\begin{array}{l}107 / 8 \\
206 / 8 \\
283 / 8\end{array}$ & $\begin{array}{l}21.6 \\
22.7 \\
24.6\end{array}$ & 23.0 \\
\hline $\begin{array}{l}119 \\
110 \\
119\end{array}$ & $\begin{array}{l}16 \\
17 \\
28\end{array}$ & $\begin{array}{l}17.6 \\
10.0 \\
20.9\end{array}$ & 29.1 \\
\hline
\end{tabular}




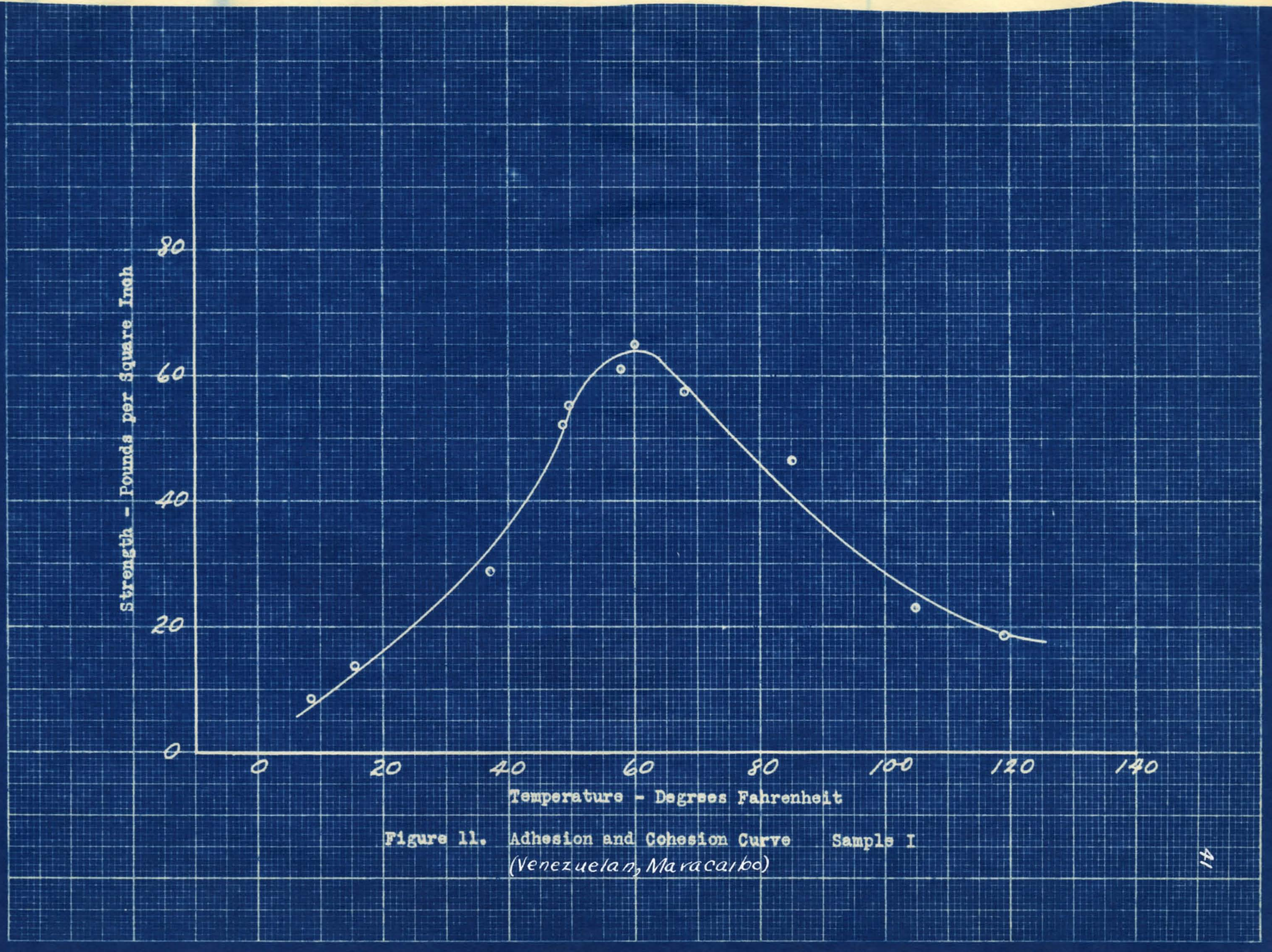


TAMLE XII

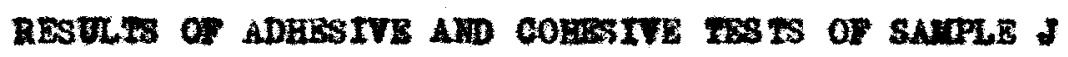

(Pure Panuco Crudos)

\begin{tabular}{|c|c|c|c|}
\hline $\begin{array}{l}\text { Tuporature } \\
\text { Thrombe it }\end{array}$ & $\begin{array}{l}\text { Whisht of Load shot } \\
\text { Pounds }\end{array}$ & $\begin{array}{l}\text { 8trongth } \\
\text { Polmde/equare inak }\end{array}$ & $\begin{array}{l}\text { Arorago strongth } \\
\text { Peunds/oqwe inch }\end{array}$ \\
\hline $\begin{array}{l}8.6 \\
8.6\end{array}$ & $205 / 6$ & $\begin{array}{r}9.9 \\
11.7\end{array}$ & 10.8 \\
\hline $\begin{array}{l}18.5 \\
16.5 \\
18.5\end{array}$ & $\begin{array}{r}85 / 8 \\
9 \quad 2 / 8 \\
14 \quad 1 / 2\end{array}$ & $\begin{array}{r}9.5 \\
10.1 \\
15.9\end{array}$ & 21.8 \\
\hline $\begin{array}{l}32 \\
32\end{array}$ & $\begin{array}{l}251 / 2 \\
271 / 4\end{array}$ & $\begin{array}{l}28.0 \\
30.0\end{array}$ & 29.0 \\
\hline $\begin{array}{l}87 \\
37 \\
37\end{array}$ & $\begin{array}{l}31 \\
52 \\
38\end{array}$ & $\begin{array}{l}34.4 \\
36.6 \\
36.3\end{array}$ & 36.4 \\
\hline $\begin{array}{l}50 \\
50 \\
50\end{array}$ & $\begin{array}{l}48 \\
87 \\
4 / A\end{array}$ & $\begin{array}{l}17.3 \\
48.4 \\
63.0\end{array}$ & 52.9 \\
\hline $\begin{array}{l}59 \\
59\end{array}$ & $521 / 2$ & 67.2 & 66.6 \\
\hline $\begin{array}{l}68 \\
68 \\
68\end{array}$ & $\begin{array}{l}115 / 8 \\
451 / 2\end{array}$ & $\begin{array}{l}18.6 \\
49.5 \\
48.0\end{array}$ & 48.0 \\
\hline $\begin{array}{l}86 \\
85 \\
85\end{array}$ & $\begin{array}{l}36 \\
36 \\
37\end{array}$ & $\begin{array}{l}30.6 \\
40.1 \\
40.7\end{array}$ & 10.1 \\
\hline $\begin{array}{l}105 \\
105 \\
105\end{array}$ & $\begin{array}{ll}22 & 7 / 8 \\
23 & 7 / 8 \\
25 & \end{array}$ & $\begin{array}{l}25.2 \\
25.4 \\
27.6\end{array}$ & 26,0 \\
\hline $\begin{array}{l}119 \\
119 \\
119\end{array}$ & $\begin{array}{l}171 / 2 \\
161 / 4 \\
201 / 4\end{array}$ & $\begin{array}{l}19.3 \\
20.1 \\
22.2\end{array}$ & 20,5 \\
\hline
\end{tabular}




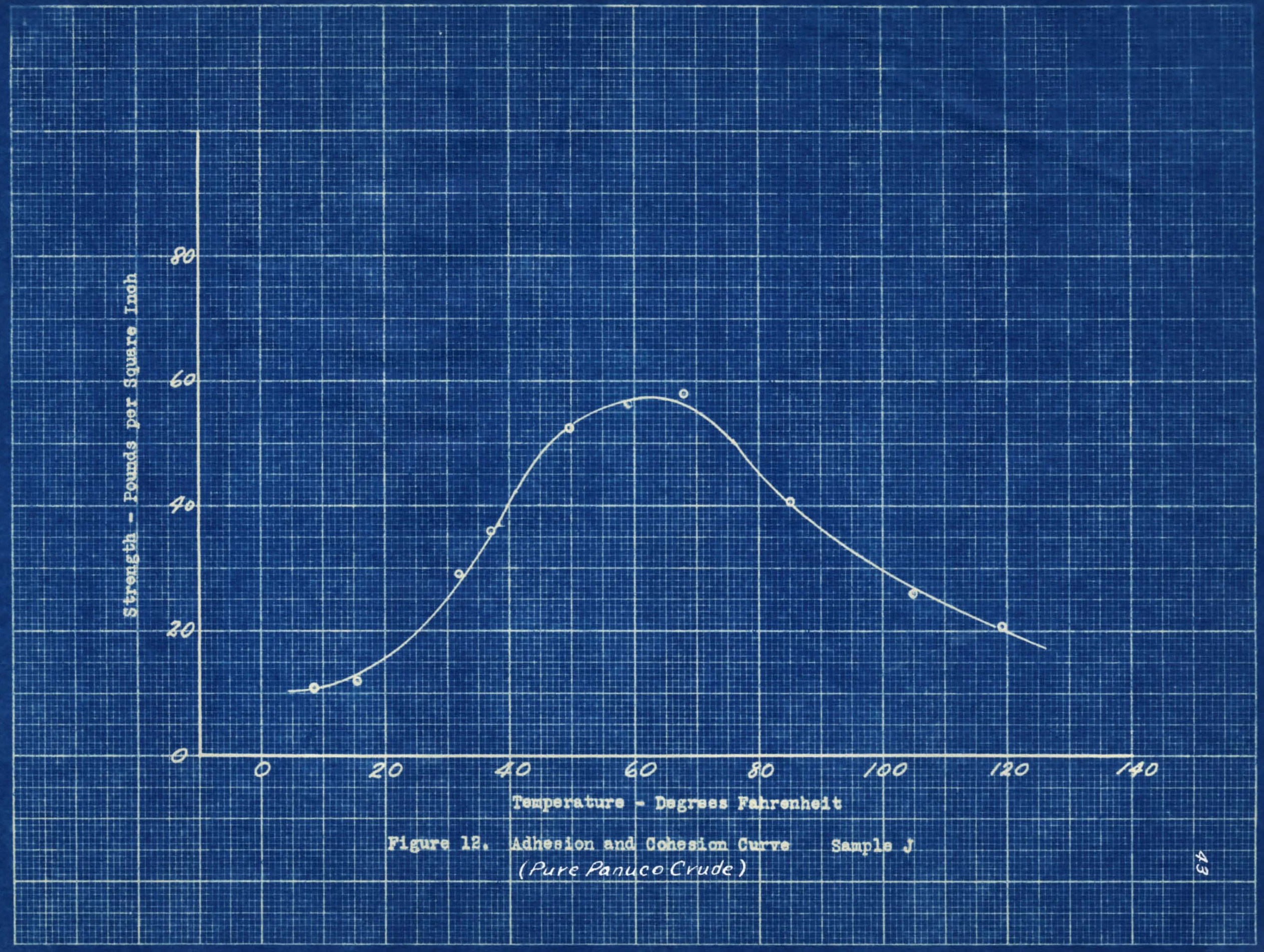




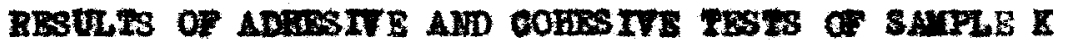

(Pure suinar Blute orvale)

Tenpeatuture Wolght of Lad shot

Thanowhest

8.6
6.5
8.5

15.5

18. 5

15.6

28

26

26

37

37

37

48

48

60

BO

68

68

68

66

86

86

106

106

105

119

119

12
Pond:

13

$181 /$

$151 / 2$

$243 / 4$

$35 / 4$

$321 / 4$

32

$361 / 2$

$871 / 8$

$461 / 2$

$50 \pi / 8$

512

$49 \pi / 2$

5 $1 / 2$

474

37

38

$41 / 4$

$293 /$

$325 / 6$

$345 / 8$

17

$10 \mathrm{3} / \mathrm{s}$

$214 / 4$

17

$175 / 6$

$156 / 8$
Strongth Pouade/equare indh

24.5

14.8

27.0

26.2

35.7

38.4

35.2

40.2

41.3

50.1

56.0

56.7

54.8

57.8

50.0

51.8

40.7

41.8

48.7

32.5

36.7

38.2

28.7

21.3

23.4

18.7

10.4

17.2
61. 3

21.1

32.7

38.9

54.2

66.1

43.7

35. 7

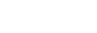

18.0

17.2
Arorag strongth Pounde/oquare Ineh 


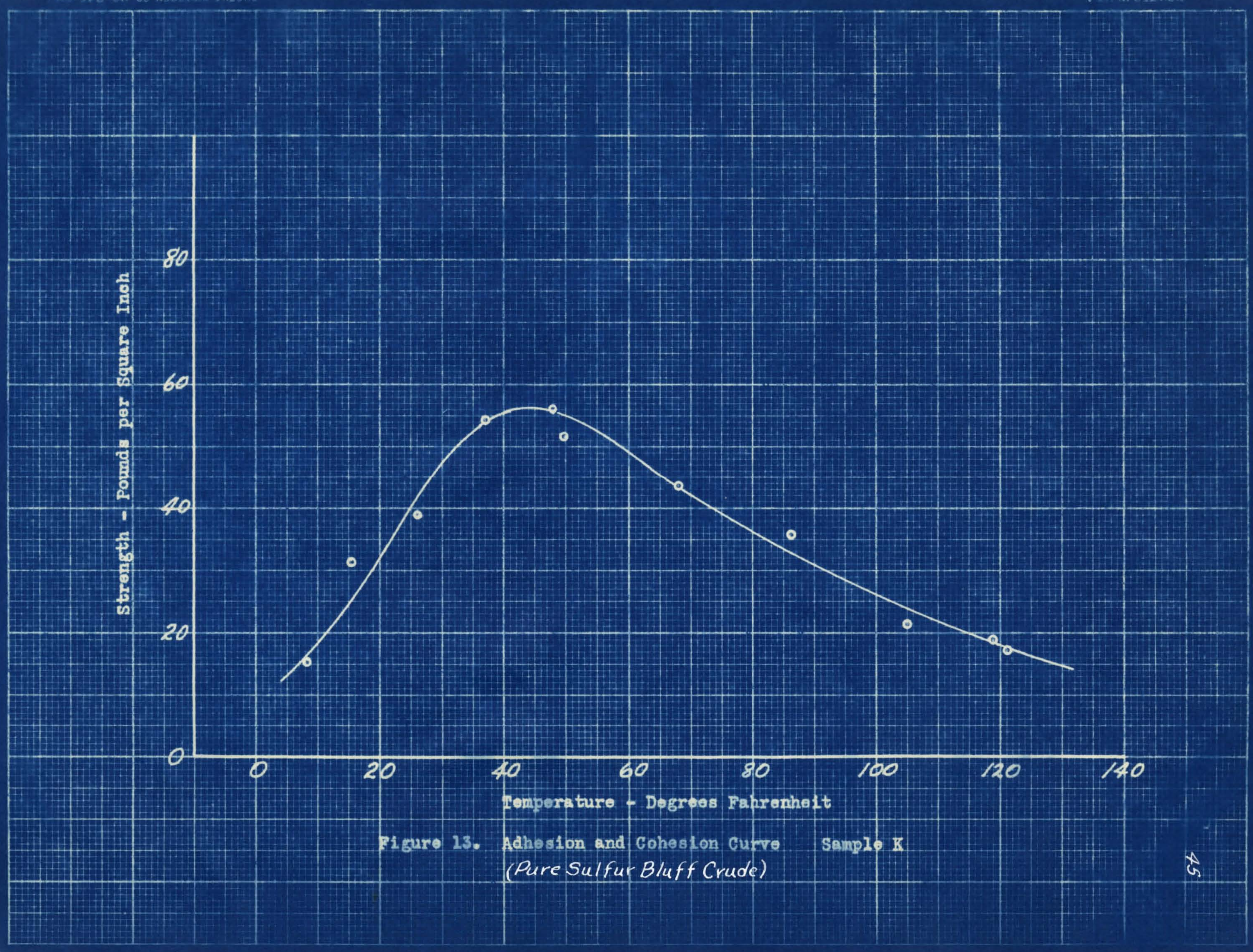




\section{TNLS XII}

RESUL

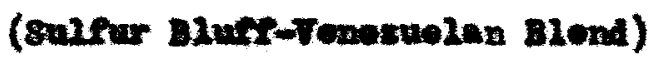

Tenpurature Tahroxbot:

\section{5 \\ 8.5 \\ 8.8}

16.5

16.6

15. 5

37

s)

37

60

50

68

b8

68

6

6

68

96

86

86

205

108

105

120

129

119
Wolght of Lond shot Pand:
$8 / 4$
$91 / 2$
$121 / 4$

21

$28 \div$

17

38

$403 / 4$

$41 / 4$

49

$867 / 6$

5

$651 / 2$

89

$173 / 4$
$503 / 8$

$343 / 8$

$563 / 4$

375

$213 / 5$

$218 / 9$

$221 / 2$

$161 / 2$

$201 / 8$

$18 \mathrm{~s} / 4$
Strength

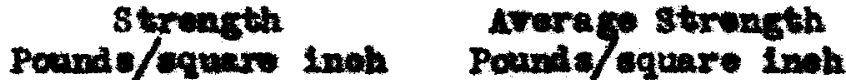

$$
\begin{array}{r}
9.1 \\
10.5 \\
12.4
\end{array}
$$

10.7

12.1

14.2

10.7

14.9

43.7

44.8

48.7

45.7

58.9

62.6

68.2

69.4

62.0

6.9

61.7

52.8

52.

65.4

87.8

40.4

4.1

23.5

23.0

24.8

18.2

10.9

20.6
39.8

24.0

53.6

.

19.6 


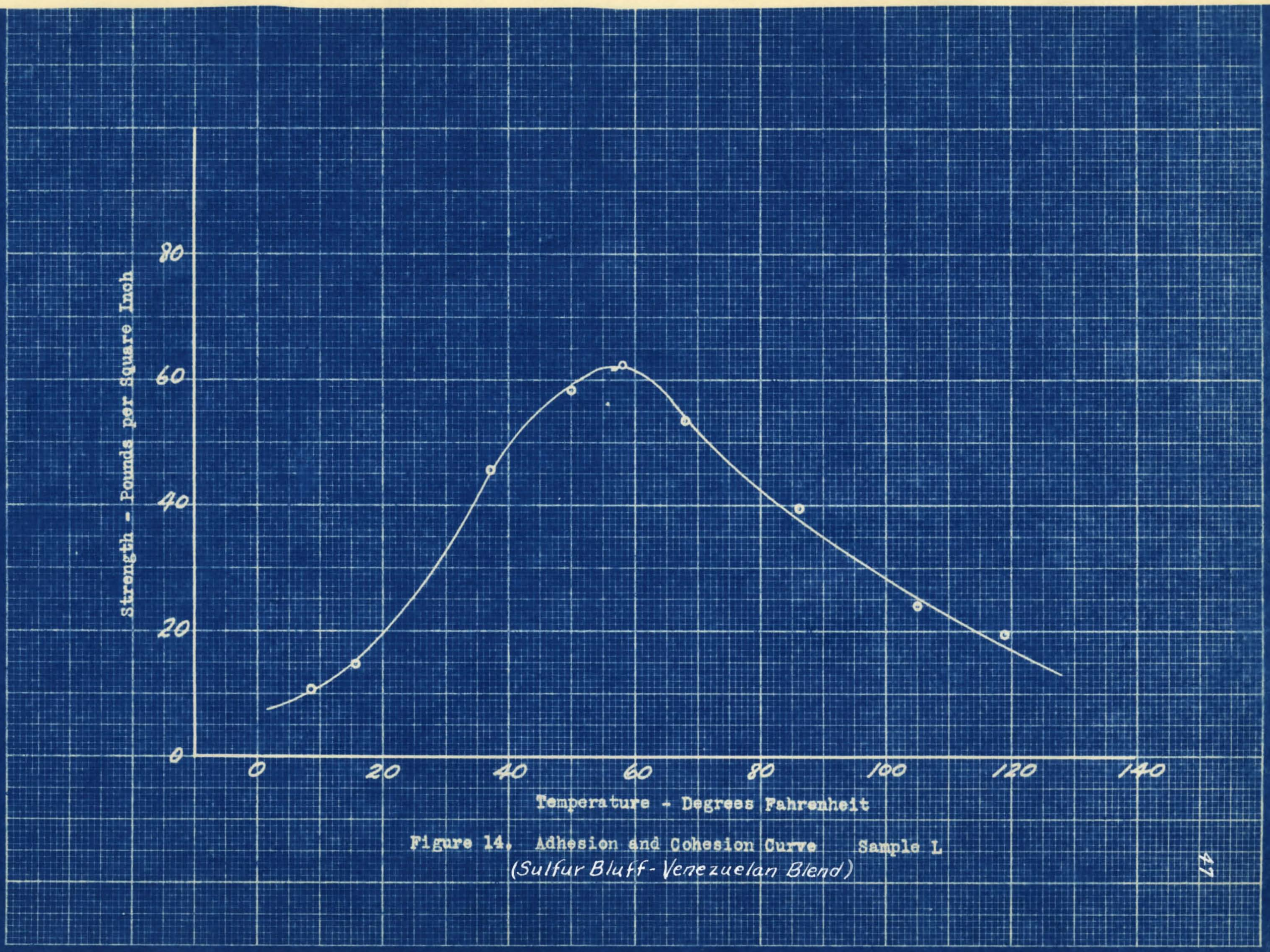




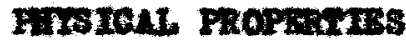


sorrentre pons

The Ring and Ball method (2) of betting for caprating point me

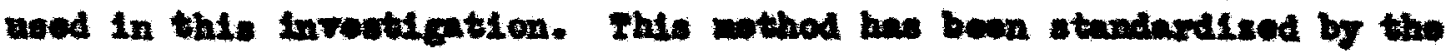
Anorioan Soetoty for losting Hatorials.

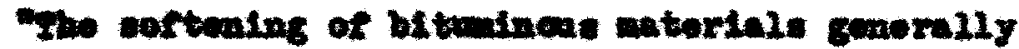

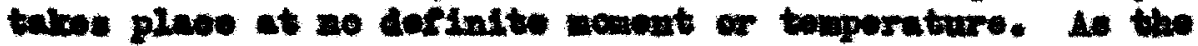

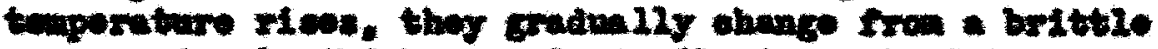

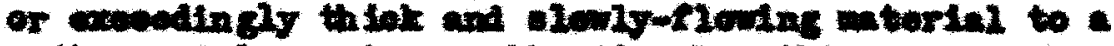

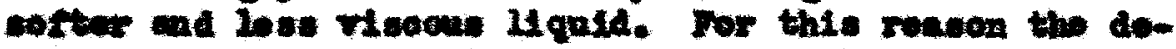

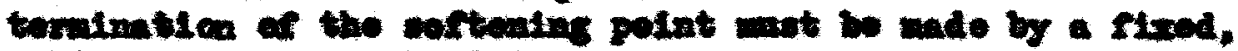

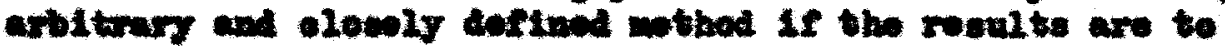
be aemparmble," (1)

The apperatur ooneinted of the folleniag

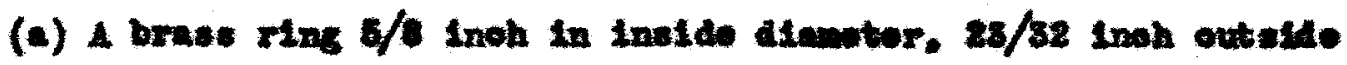
dinoter, and $1 / 4$ ineh deop.

(b) A atwel ball $3 / 0$ inoh in dinuobor welghing betwoen 5.45 and 8.95 grano.

(e) In 800 0.0. clase beaker. 20 fem.

(d) $40^{\circ}$ to $200^{\circ}$ palurached theirnemotor."

The angle was welted, otirred theronghy, and pourod Into the

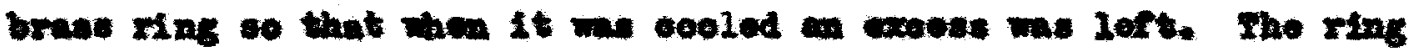
rested on in andignated brass plate to provont the aphalt fron ad-

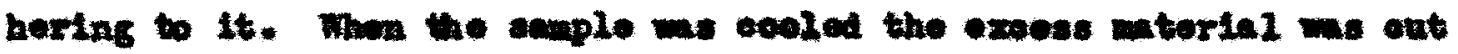
of aleanly with a botod getrelk.

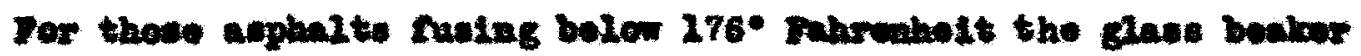

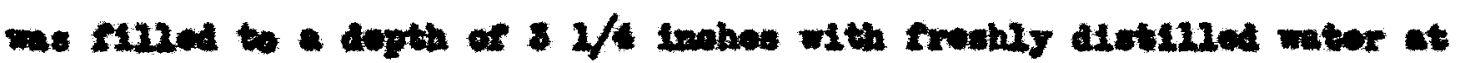

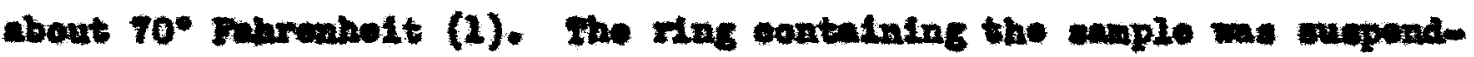

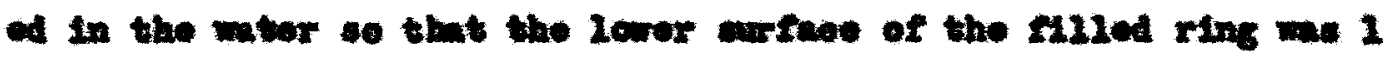

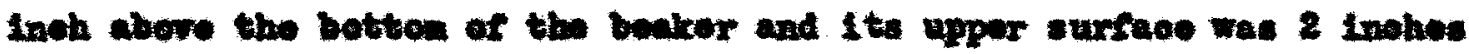


bolen the eurfeo of the mutor. The ball we plaed in the wator ot

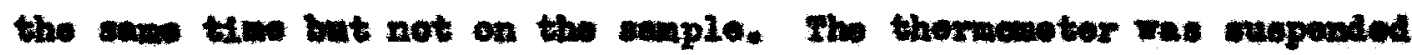
oo that the bottem of the bulb was lwal at th the botten of the ring. The ball and rins wre allemed to remin in the water for firtem

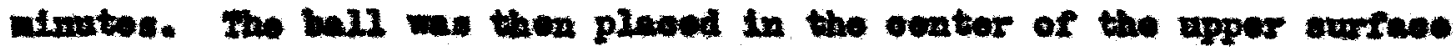
of to aphalt in the rine and the wter heated by wowe of a and Buncon rime.

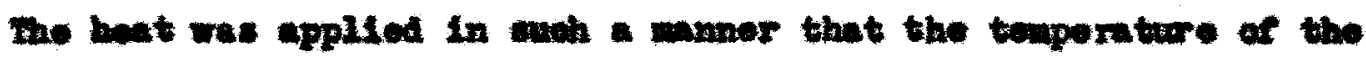

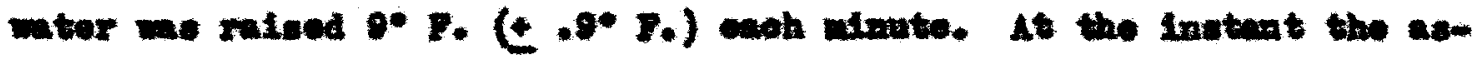

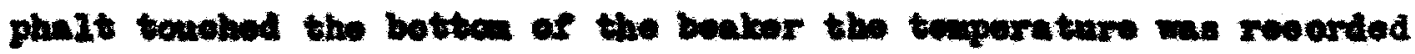
and roported at the cactonding potet.

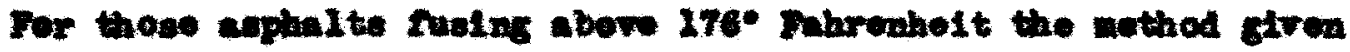

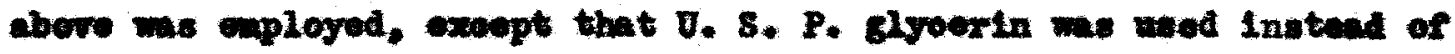
menter.

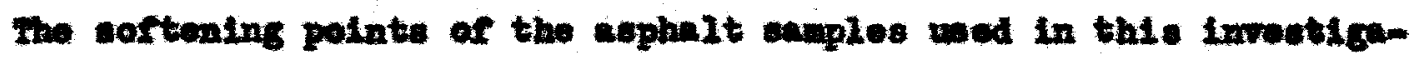
thon are edron in Table X. 


\section{7nts}

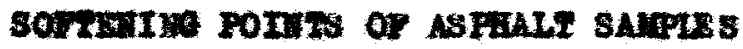

Sample

4 (Tonotaolen, Legualine)

B (Tonosualen, Lagailas)

- (Mtrea Toxae Erudos)

D (Senth tworienn Grades)

B (uxod toxas Grutes)

7 (rezene Grades)

- (Venotuolen, Emostbo)

If (Vemosudan, Hrecalbo)

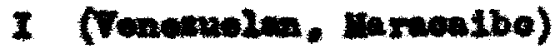

I (Pure Panue Orude)

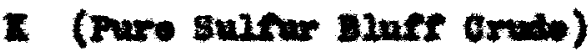

L (Bufru Bluex-7onornolm Blow)
Tenpernture

Tahroaladt

290

276

200

201

17

201

10

208

102.6

199

104

280 


\title{
Wustarto
}

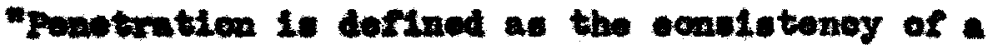
bituninou matorial, expreseed as the distanos thet a atandard soedle vortieally penotratea enple of the

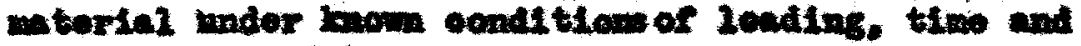
temporature." (1)
\end{abstract}

4 isoteh of tho penotioneter chowing the eneontial parts is given

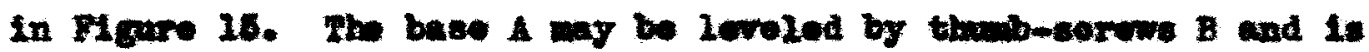
attagod to the standard ond alo the platen $D$ on wheh the sample

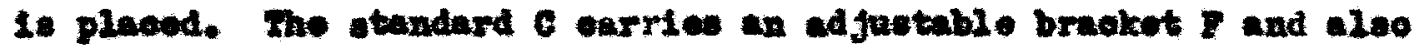
the dial $\mathrm{I}$. Wheh wearares the penotration in ono-tonth alliluoter,

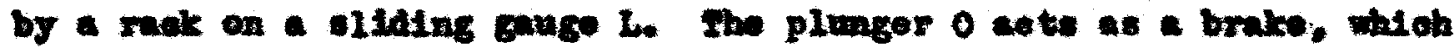
holde the wealle bar with 2 ead $w$. Whon it is proosed lward the plungor permite the neale and reight to at upon the tost aumple without friotiea.

The contalner for bolding the exphalt to be teated we natbettened, orlindrion dieh $8 / 16$ inobos in dianoter and $18 / 0$ inohos 40op. I hardened and highy pollehed nowde. approxdmately 2 inoheo

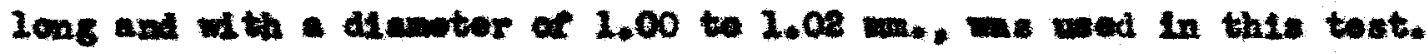
It was onmotrieally tapored at one ond to a cone approxtiately $1 / 4$

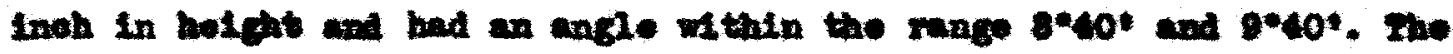
taperva end was of the sbope of a trunonted eone, the mallor base of wioh we from 0.24 m. to 0.16 wo in atanoter.

The anple of aphalt was cemplotely molted at the lomest poestble vemperature and etirrod thoroughy uthl it mo froe from atr bubbles. It we then powred into the eantalinor to a copth of loot $5 / 6$ inoh.

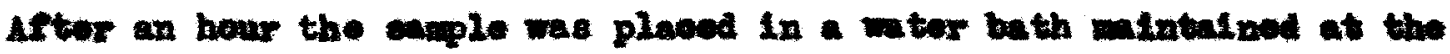




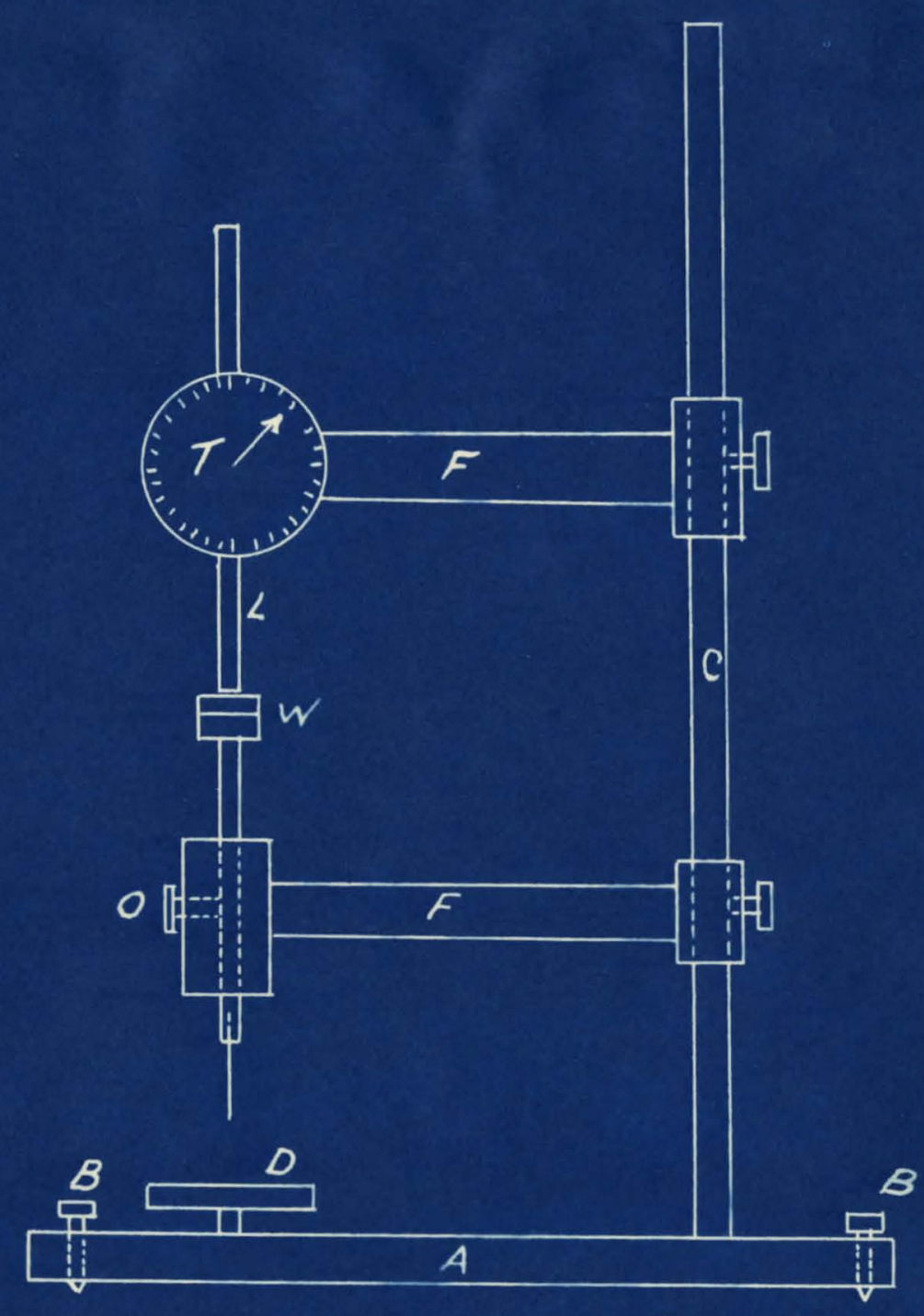

- Figure 15- Sketch of Penetrometer Showing Essential Parts. 


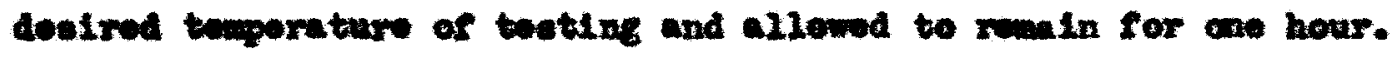

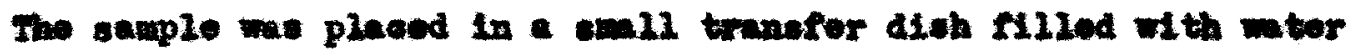

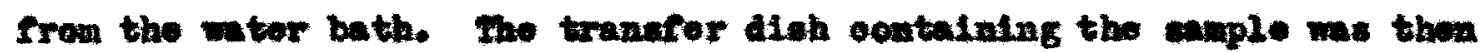
plead on the stend of the panotrompter.

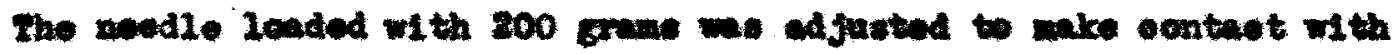

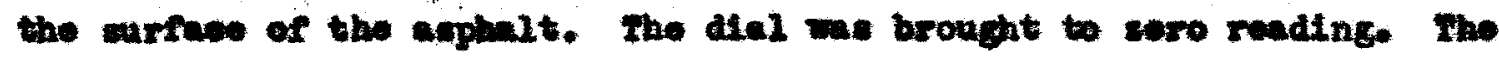
noedle we releaned for 5 seconde, artor whah the depth of ponotration

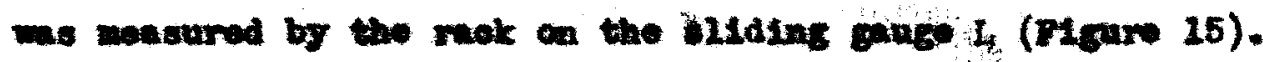

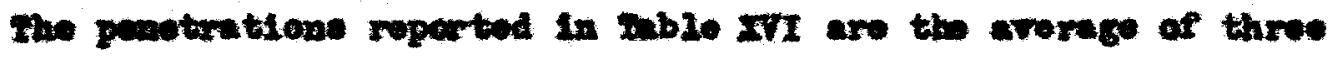

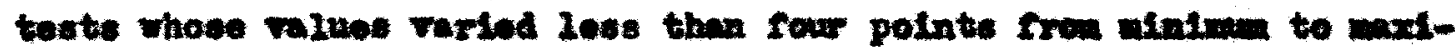
mun. 


\section{RALE XII}

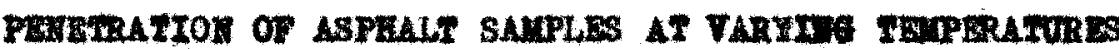

sample

4 (Venocusins, Legrallins)

B (Tonosve len, Lagualues)

- (uined Texes Cruites)

D (Seuth Imorleas Crudea)

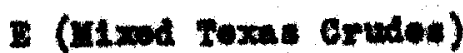

Y (Tome Orudes)

- (Tonosuelen, Maraentbo)

II (Tonousulan, Maracalbo)

I (Tomosw 1en, Larmoalbo)

J (Pure Paneo Crude)

I (Pure sultur Blurt crude)

L (sulfur Bluce-7onoswolan Blend)
Ponotration 200 6n: $/ 5$ se0. at 390

$\begin{array}{ll}10.5 & 17.6 \\ 14 & 28 \\ 16 & 28.5 \\ 11 & 28 \\ 17 & 28.6 \\ 10.5 & 17 \\ 16.5 & 26 \\ 6 & 9.5 \\ 8 & 16 \\ 21.5 & 20 \\ 16 & 26 \\ 11 & 26.5\end{array}$

Penotration

$20000 . / 5$.00. at $58 \%$

Funatiration

$200 \mathrm{gme} / \mathrm{s}$ at $\boldsymbol{r} \cdot \mathbf{T}$

Penotration

200 ges. $/ 5$ sec. at $100^{\circ} \mathrm{F}$

46

26.6

64.6

36

86

66

26

48

80.5

6

26.6

48

89.6

66

29.5

62.6

86

64

$\mathbf{s 1}$

62

42.5

31.5

54.6 


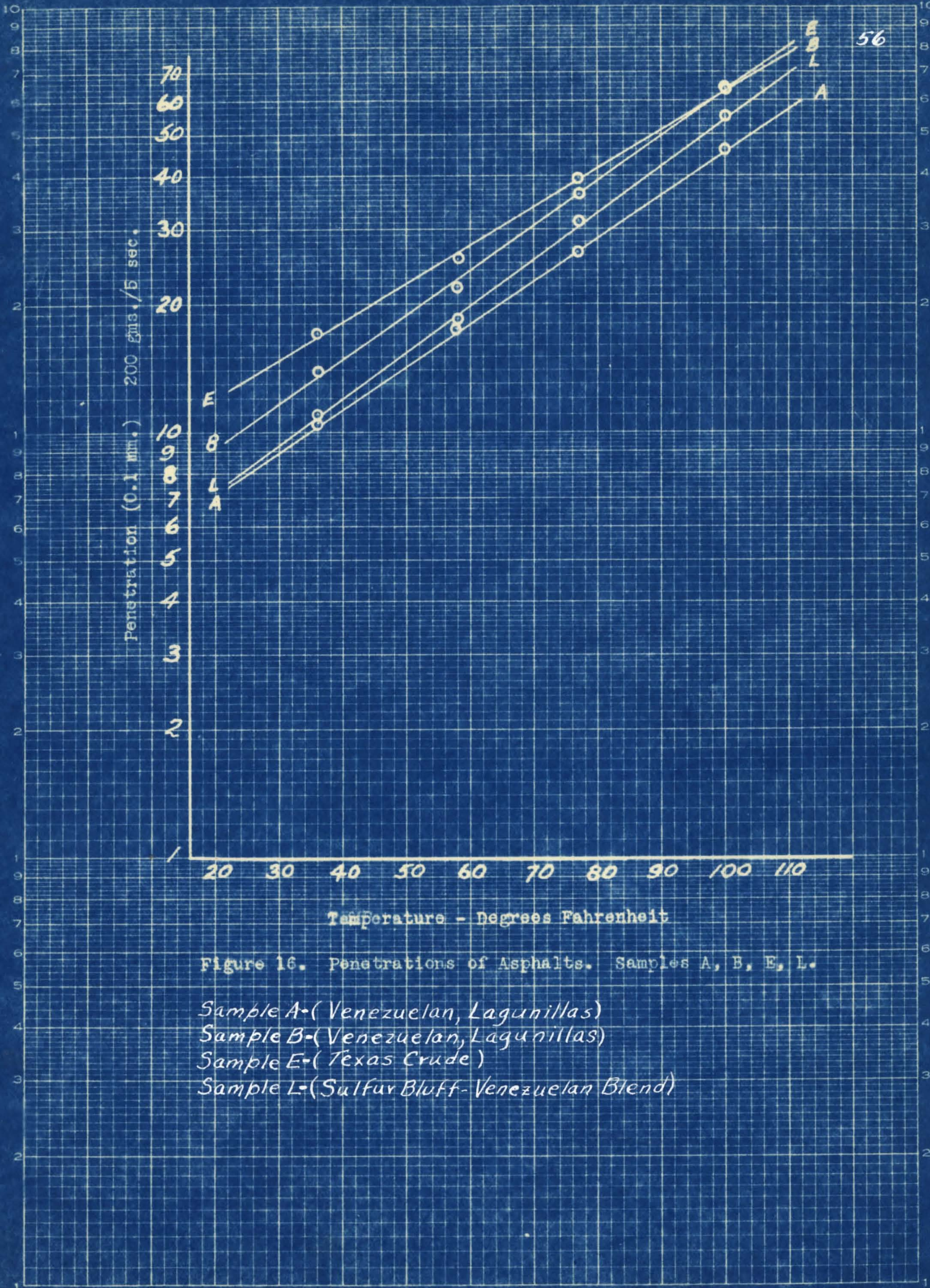




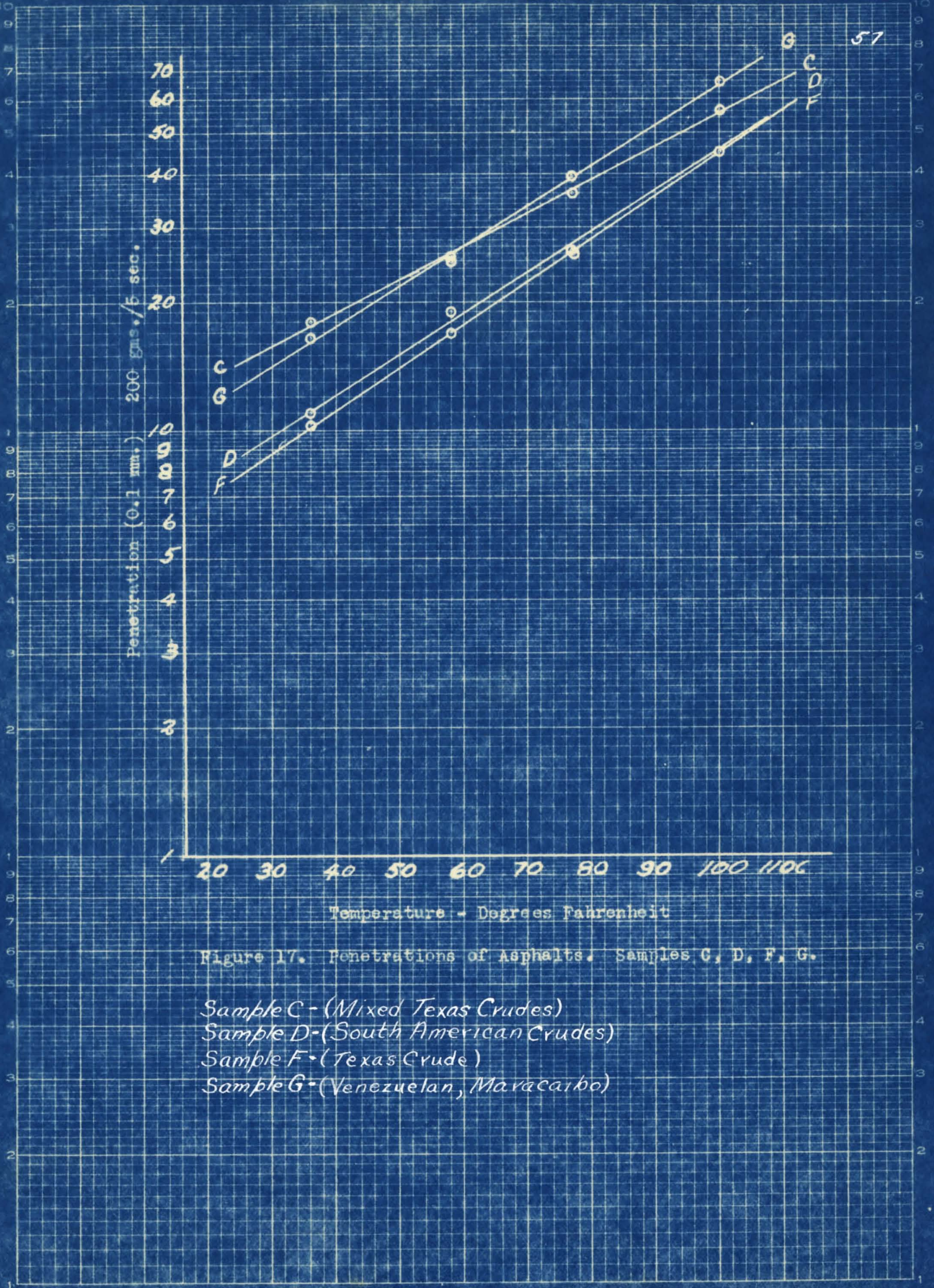




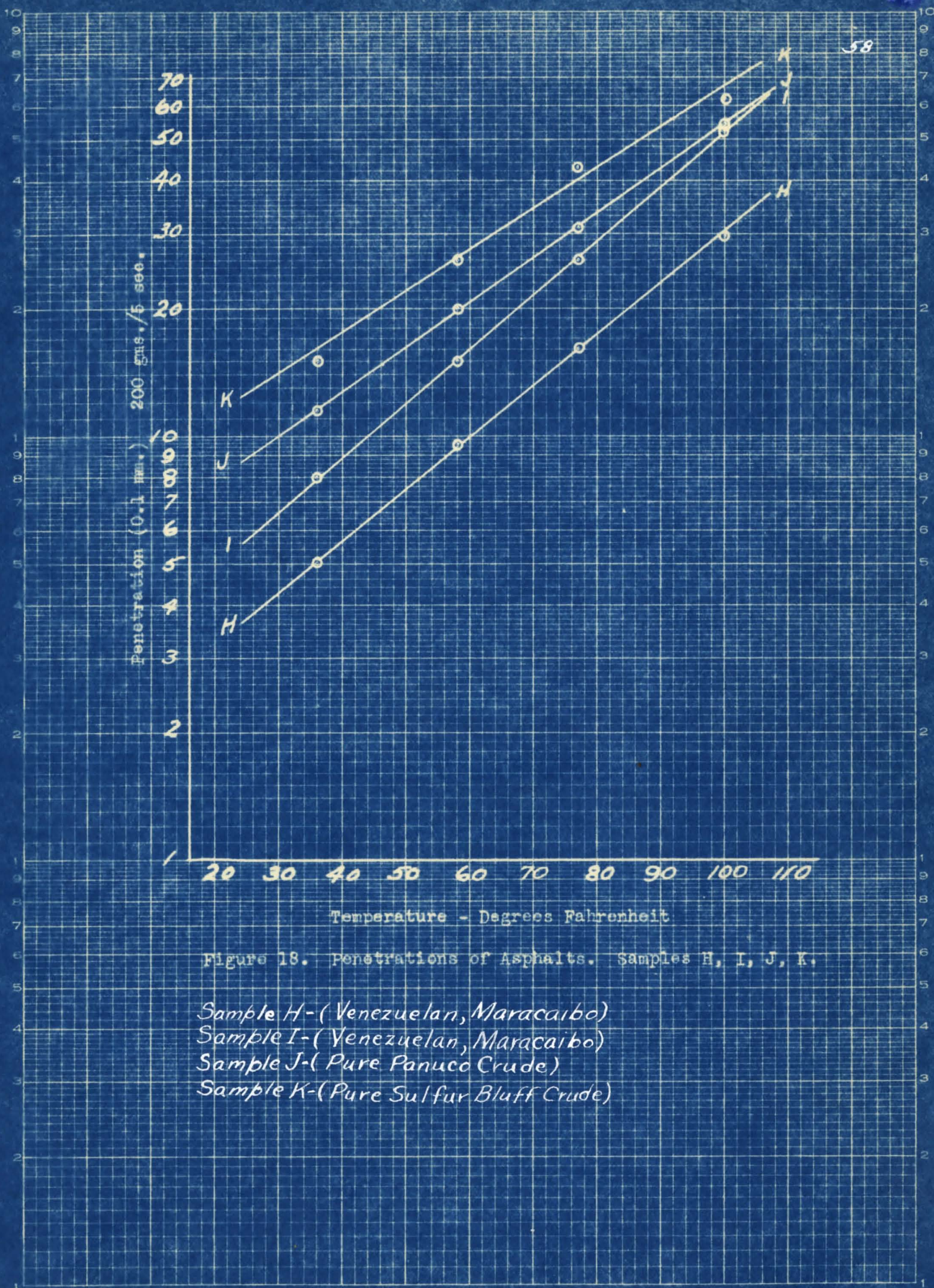


DTSCESSIOU OF RESULTS 


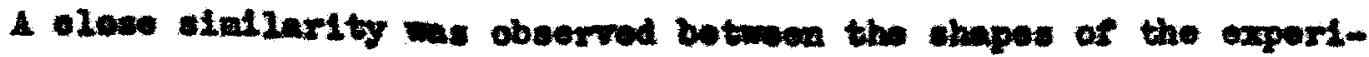

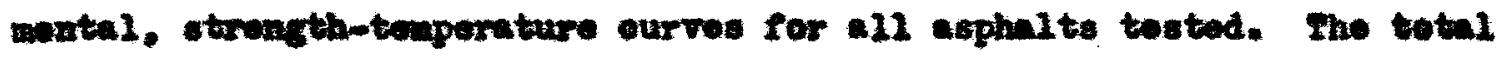

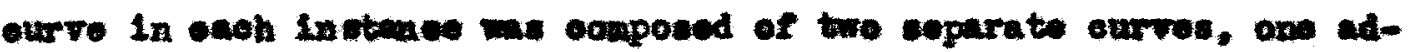
hosion and the other cokeston.

Theoretionlly the adhenion, ourve $x$ (Figure 4), inorouses wt in-

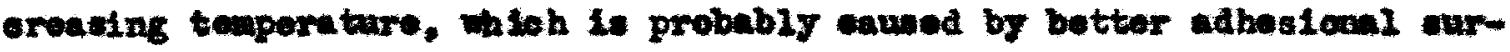

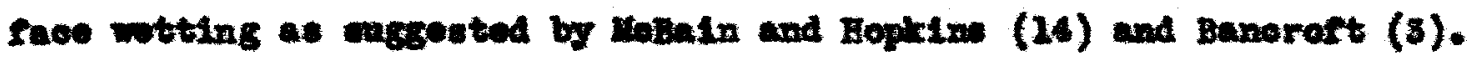

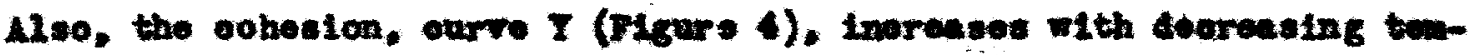

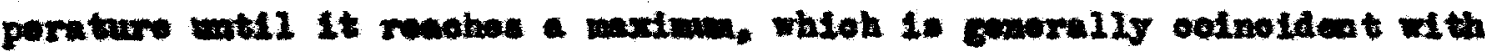
the temperature at when the duetulity is sare (1).

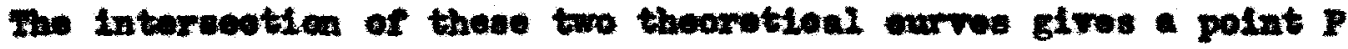
(1gare 4) at which the adhesive and oohestre strongthe are equel at the

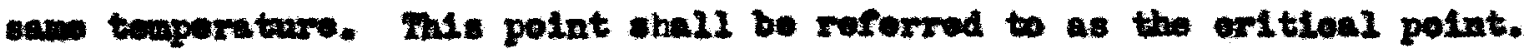

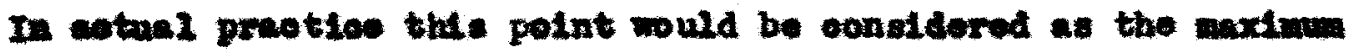

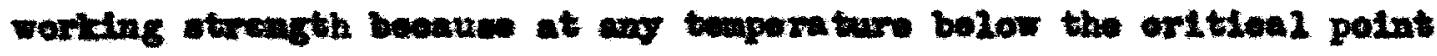

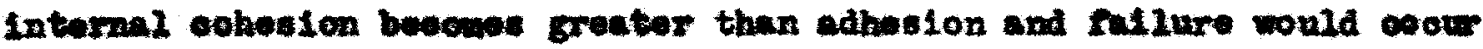

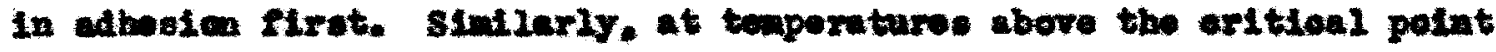
achosion is greater than cohosicn, therofore, fallure would oogur in sokvelen.

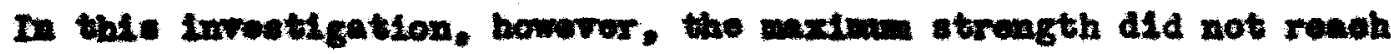
the oritienl polnt, and the ourve reuded off elighty belor this polnt. The we eanod by the eample breaklug in a combination of adboston and ootwaton in the rogion moar tho ortbleal point (Figure 20). In onlor to roach thls potnt the eamples would hre to break in adhesion alone at ay temperature up to the oritieal point and in oohosion 
at as bemperabure above it.

It was obeorved that the faster the rate of loading the wore noar-

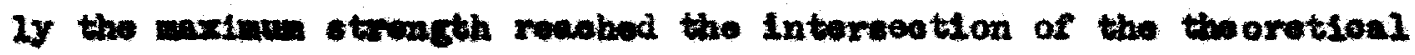
ourves. Thes it appears that in onder to obtain the true maximum strongth the load would bare to be applied at a rote swoh thet fallure of the sample ocourrs Instantaneouny on appliention of 20 d.

From obsometion of the experimontal data, there nas no warrelation of adhesion or cobeston with tho oomonly soopted teste. penotration and saftentus polnt. Welther did the duotility dat as

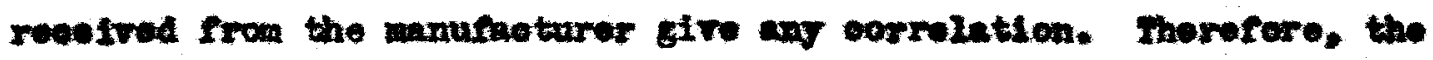
boat wothod of dotemining the qunlity of adaptablity of an abpholt for comontling purposes would be a dreet mosonrenent of adhesive and oobonire abrengths as oarried oat in this Imvatigation. 
suniny Am carcustous 
wher the vorking conditions of en caphalt oonont aro epoefitid for axy epplitation the aroe inolosed by the temperntare Linite and the dealred strength must fall wad the etronghh-temperntwre anves otherwise, the asphalt wII rail in tension. In thome caves whore the necessary working conditions are known this tost oould

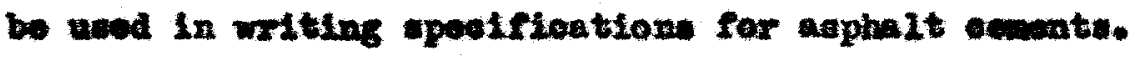




\section{AFEDXX}




\section{Senple celoulatsons}

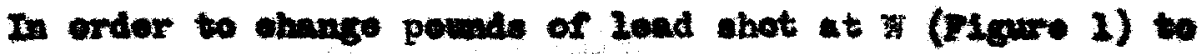

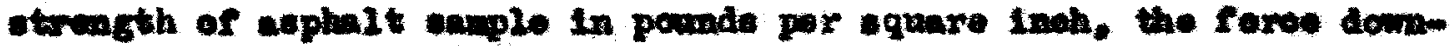

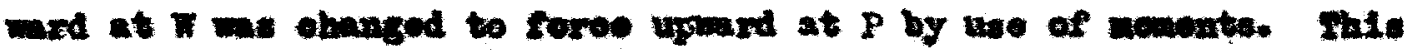
rajue of tores $p$ me Alvided by arow of aphalt layor on test ponelo to obtaln etrough in peande por equare inoh.

Area covered by aephalt anple (fron Higure 2) -

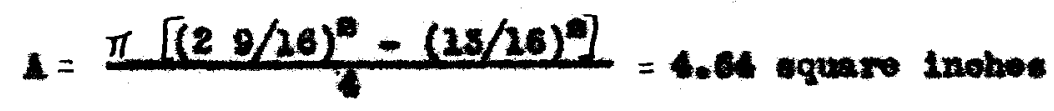

Feree at P (rrom Figure 1) -

$$
\begin{aligned}
& \text { V } x 27 \quad / 4=P \times 35 / 6 \\
& P=\frac{171 / 4}{37 / 6}=6.212 \pi
\end{aligned}
$$

Strength in penade per equere inoh -

$$
s=\frac{P}{I}=\frac{5.111 \mathrm{~W}}{. .65}=1.20 \mathrm{~W}
$$


Lterature cited

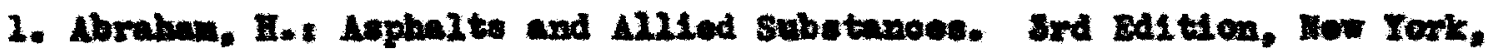
Van Nostand Co.e 1909.

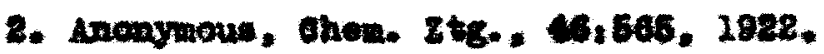

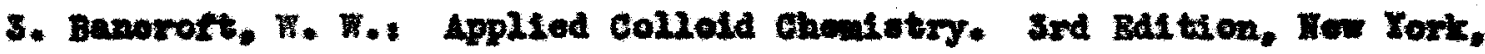
HoGraw-HIII Book Co., 1932.

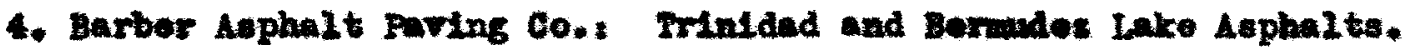
Phizadelphia, p* 28, 1989.

6. Bartoll, F. E., and Oaterhor, E. J., J. Phyt, Chom, 341399, 1930.

6. Boorman. T. H.1 Apphalts. How Tork, Din. 2. Constook, 2008.

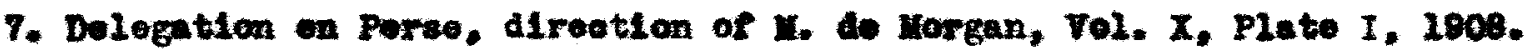

6. Dupre, Chew. $2 t g ., 4,445,1918$.

9. Goldmen, 0. 6., v. S. Pat., 8,113,785 (Apri1) 1035.

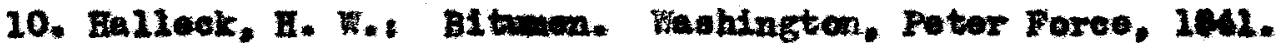

12. Bolmos, A., A. S. T. H., a, 21140-1149, 1939*

12. Hoover, O. R., and Shafor, O. E., 0. S. Pat., 2,020,691 (Nov,) 1956.

13. Lowil and Wolbora, Pablio goads, Yo2, 21, No. 1, (Maroh) 2040.

14. HoBain, J. W., and Hopkins, O. O., 2nd Roport of Adheatres Researoh Cowaleston, 34-89, 1926.

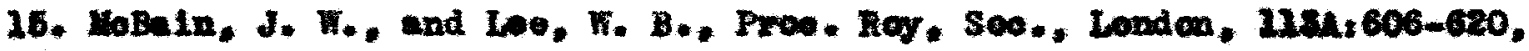
1027.

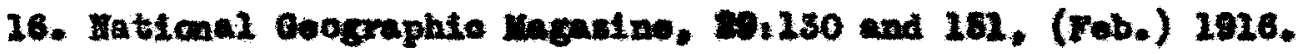

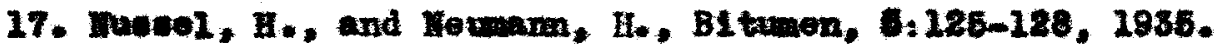

18. Paleigh, Walter (sir), DLoovertea of Culara

19. Ramay, W. Not on Potrolou, J. Soe. Chom. Ind., St287, 1983. 
20. Moded, W., and Wober, B., Aaphelt Toer Straseonteoh, H, 006-012, 2023.

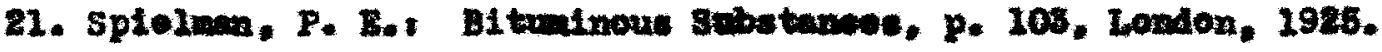

22. Jayler, A. A.. Tram, Faraday s00., 4,167-160, 1928.

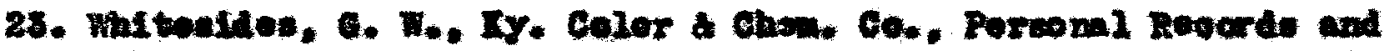
Gorroppendonos, $1089-1040$.

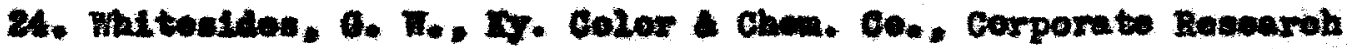
Reoonde. 1926-1940. 



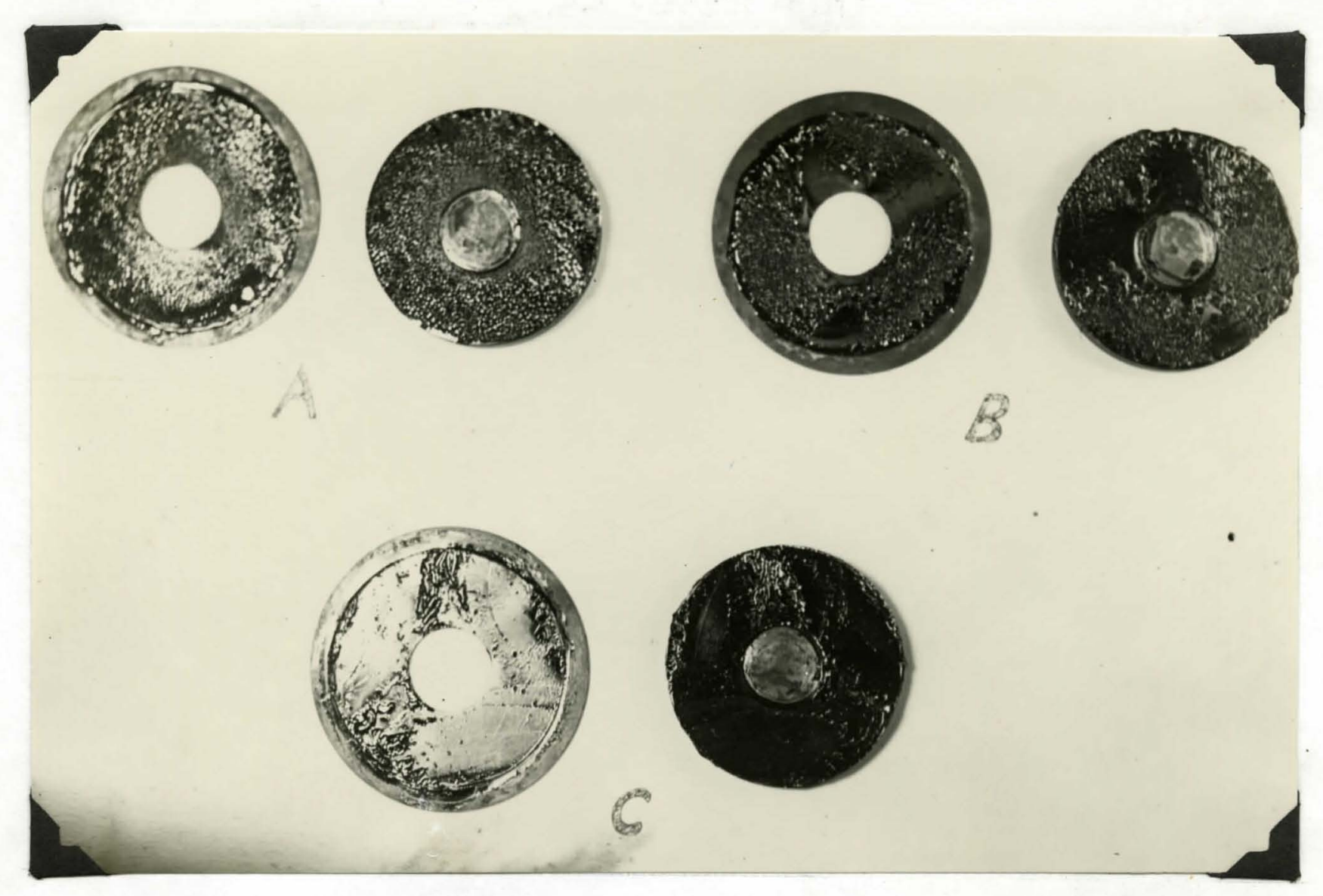

Figure 20, Test Panels after Break.

(A) Break in Cohesion.

(B) Break around Region

(c) of Critical point. 
Tho Inthor whes to exprese bis aln-

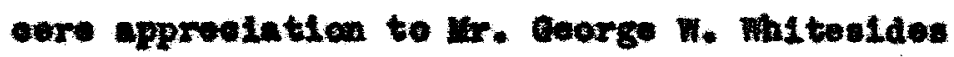
for his holptel mageotlone and to Iratuoly Coler and Chomloal compary for wost of the metoringe ned in the inreotigation. 
Tru

\section{Inreld Rees}

In atbor, Iareld Roes, son of Jamos $X_{*}$ and targeret

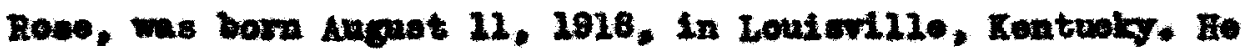
obtained ariwary edvoution in the Loulerille Publio Sohoolo

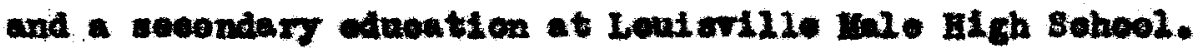
After graduting fren High Sohool in Jupe, 1055, he entered the spoed solentifte sohool. Dasveresty of Loaforille, in

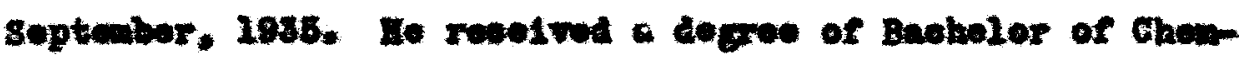

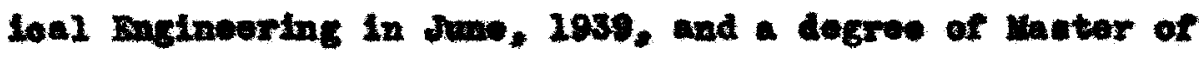

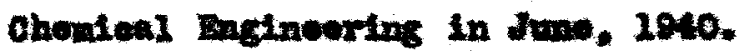

Inchetrial experienoe was obtalnod at the follewings

1. Cohort Rofrattories Co*, 16th Leo, Loulorille, Xy. 3 montine, 1036.

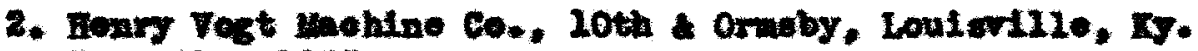
3 weathe. 2887.

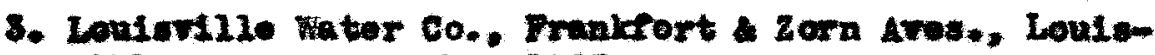
r112. IY.. 5 wonth: 1957.

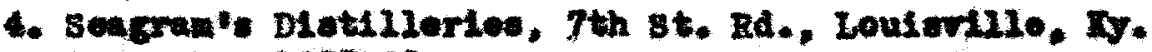
8 monthe, 2037 -38.

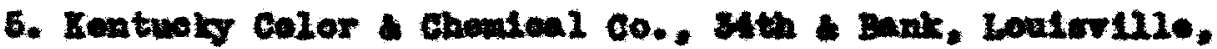
$\mathrm{Ky} \cdot 14$ nonthe, $1958 \mathrm{~m} 4 \mathrm{.}$

While an wadergraduate ho played throe yoers of varulty

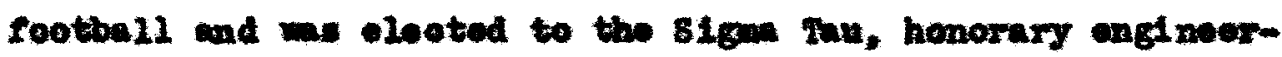
Ing fratoralty. 